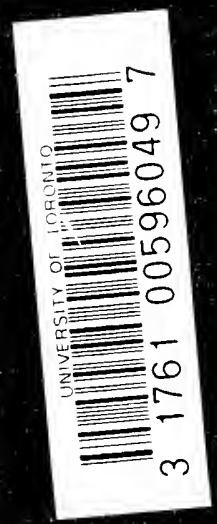






\section{GERMANY PUSHES SOUTH-EAST}





\section{GER M A N Y PUSHES}

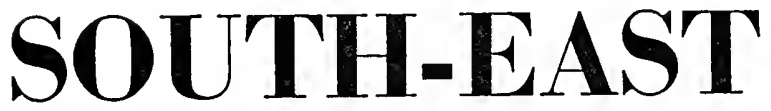

by

Dr. Gerhard Schacher

Author of "Central Europe and the Western World"

3rd Impression

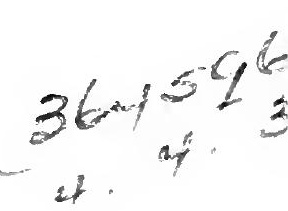

Publishers since 1812

Hurst \& Blackett, Ltd. 
Made and Printed in Great Britain for Hurst \& Blackett, Ltd., Paternoster House, London, E.C.4, at the Anchor Press, Tiptree, Essex. 


\section{PREFACE}

Pan-Germanism is pushing South-East.

Its dream is the creation of a mighty, self-contained empire reaching from the Rhine to Western Asia. Though its aspect and methods have changed since the days of the Hohenzollerns and the All-Germans, it is essentially the same. The "Drang nach dem Südosten", which led to the European conflagration of 1914 that ended in Germany's collapse, is once more spreading unrest.

The aim of this book is to show the historical origin of the push South-East and the political and economic methods it adopts today. It names the allies which National Socialism makes in its endeavour to hinder consolidation in the South-East, and demonstrates that the best ally of the push South-East is the illusion that security for the West can be purchased by allowing Germany an outlet for its expansion and a free hand in the South-East.

This book is intended as a contribution towards the recognition of the fact that European peace is indivisible. The author believes that there is today no political axiom of greater importance for the fate of this Continent.

If he has been able to spread the recognition of this truth his purpose is achieved.

Dr. Gerhard Schacher.

Prague,

Autumn 1937. 



\section{CONTENTS}

PAGE

PREFACE

INTRODUCTION : PAN-GERMANISM AND NATIONAL SOCIALISM .

ix

Part I: The Historical Roots of the German Push South-East

I. HOHENZOLLERIS AND HABSBURGS • •

II. PAN-GERMANISM IN THE ORIENTAL QUESTION AND THE BALKAN WARS

III. GERMANY'S GENTRAL EUROPEAN PROPAGANDA AND THE WEIMAR REPUBLIC .

Part II : German South-East Policy under Hitler IV. OLD AIMS-NEW METHODS? • • • 55

V. THE REACH FOR VIENNA

VI. THE ATTAGKS ON PRAGUE $\quad$. $\quad . \quad$. $\quad 82$

VII. THE STRUGGLE WITH THE LITTLE ENTENTE IOO VIII. A REVISION OF REVISIONISM ? . • . I2O IX. BERLIN AND THE BALKAN ENTENTE - I 30

Part III : German Economic Strategy in the South-East

$X$. THE THIRD REICH'S METHODS OF OBTAINING FOODSTUFFS AND RAW MATERIALS - I4I

XI. GERMANY'S ECONOMIG POLICY AND ITS EFFECTS ON THE STATES IN SOUTH-EAST EUROPE . 


\section{$C O \mathcal{N} T E \mathcal{N} T S$}

XII. GERMANY'S SOUTH-EAST ECONOMIC STRATEGY AND THE GOLONIAL PROBLEM • I6O

XIII. THE BIG GUSTOMER AND HIS POLITICAL BARGAIN

Part IV: The German Policy of Intervention in the South-East and the Organization of National Socialism Abroad

XIV. THE PRINGIPLE OF INTERVENTION -

XV. THE "VOLK OHNE RAUM" AND THE GERMAN

BROTHERS IN THE SOUTH-EAST . . I8O

XVI. HOW ARE THE GERMANS ABROAD PROTECTED? .

XVII. THE "DRANG NAGH DEM SÜDOSTEN" IN 189

ALLIANGE WITH THE NON-GERMAN FASGIST ORGANIZATIONS .

XVIII. MINORITY POLIGY IN THE THIRD REICH AND

IN THE SOUTH-EAST .

Part V: The Push South-East and the Democracies of Western Europe

XIX. THE SEA-ROUTE TO THE EAST AND THE LAND ROUTE TO ASIA

XX. WHIGH IS IT TO BE? LONDON-PARIS OR ROME-BERLIN? .

XXI. THE EUROPEAN EQUILIBRIUM AND THE SOUTH-EAST . . . . . . 238

XXII. INDIVISIBLE PEACE OR INDIVISIBLE WAR • 244 BIBLIOGRAPHY 


\section{INTRODUCTION}

\section{PAN-GERMANISM AND NATIONAL SOCIALISM}

Since July 3rd, I866, the day on which Bismarck concluded the Prusso-Austrian Peace, German imperialism has signified for Europe a disturbing element that with brief intervals has driven this unhappy Continent from war to war and from crisis to crisis. In the form of National Socialism the pan-Germanism that suffered such a rude setback through the defeat which was its portion in the World War has taken on a new upswing, possibly more menacing than its predecessors.

After a short period of introspection which followed the end of the War, efforts towards a fresh pan-German expansion began to manifest themselves with growing emphasis from year to year. Combined with other moments of an economic, social and cultural nature, these imperialistic currents-which at the time of the Weimar Republic were only rightly observed and appreciated by those whose voices were unfortunately all too little listened to outside the frontiers of Germanyswelled in volume up to the seizure of power by National Socialism. The old ideas that only Germanism held a cure for the world, that the German nation was predestined over and above all the other peoples of Europe to fulfil a special historical mission, and that it could only accomplish this mission through "blood and iron", again came to the forefront.

A superficial observer of developments could thus see in the totalitarian system of National Socialism in ix 
Germany little more than a rebirth of pan-Germanism. The conclusion could be drawn from this that the wreck which German imperialism had suffered in its collision with a united Europe in I91 8 must now of necessity be repeated if the German efforts at expansion were opposed by the same methods as up to I9I 4 and during the War.

A closer cxamination, however, reveals the fact that while a whole scries of important features can today without hesitation be compared with those of the last few years prior to the War, the situation in other, at least equally important spheres has undergone a fundamental change. A schematic comparison of conditions in the year 1937 with those of the year 1914 is impossible. Within this period the distribution of power in both the political and economic sphere has greatly changed. An international economic and currency crisis has today shaken the whole world. The ideology of large sections of the leading civilized states has undergone great changes not unconnected with this economic crisis. Through the new distribution of fronticrs, which for about two decades has affected in particular the Eastern and South-Eastern nations of Europe, other strategic and political postulates have arisen which must be considered if a clear picture of the position that today seems so confused is to be gained. The fundamental character of the peoples remains, of course, as it was. The roots of pan-Germanism in particular are almost wholly the same as those of pre-War times.

What effect has this pan-Germanism, springing from the same roots as before but working with greatly changed methods compared with I9I4, on presentday Europe? In the first place it is essential to clear up thoroughly the question of the direction of the 


\section{$I \mathcal{N} T R O D U C T I O \mathcal{N}$}

thrust taken by the German efforts at expansion. It must be borne in mind that since Bismarck's time the struggle between the so-called Western and Eastern orientations in the leading political and military circles in Germany has never died down. Both the Wilhelmstrasse and the German General Staffalways had in hand two different plans of German expansion and of military operations. Hardly ever was the one orientation fully abandoned in favour of the other. German policy, however, practically always found itself in the danger zone when those in authority could not decide upon a clearcut orientation, and thus came within the vice between the two great Continental Powers, France and Russia.

In 1933, as National Socialism seized the power in Germany, it was almost universally assumed that this would mean the end of the struggle between the Western and the Eastern orientation of German policy and of German strategy. Despite the friction in the sphere of internal politics between the new régime and "Bolshevism" increased tension in the external sphere was scarcely observable between Berlin and Moscow. The policy of the Third Reich was directed with singleness of purpose against the Western European wartime Allies, and in particular against France. In the East and in the South it appeared as if as far as possible nothing but neutrality or indeed friendship was desired. The idea of a severance of Europe into two camps was present at the cradle of National Socialism, and even if Hitler in his Mein Kampf is not sparing in sharp threats against the Russian system of government, against the Slav nations, and so on, there runs like a red thread through all his declarations in the sphere of foreign politics an effort to characterize France as the hereditary enemy of Germany, and to $\mathrm{xi}$ 


\section{INTRODUCTION}

direct the policy of the Third Reich in peace and in war as sharply as possible towards the main aim of reducing France to impotence.

Whenever the German Dictator speaks in his bookwhich to this day is designated as the sole standard authority for his opinions - of East and South-East, it is a matter either of a mere manœuvre for the purpose of diverting attention or of an endeavour first of all to weaken the fighting capacity of the West to such an extent through the enfeeblement or the neutralization of its Eastern allies that the thing really desired, a fight against the West, could be facilitated. This fight against the West is not demanded in a defensive but in a direct aggressive form.

As long as the eternal conflict between Germany and France is carried on only in the form of German defence against French attack it will never be decided, but Germany will assuredly from century to century lose position after position. (p. 766$)$. $^{*}$

This conception of National Socialism could on that account seem at first sight quite meaningless and due merely to resentment if one were to overlook the fact that this singleness of front against France is to serve as means to an end. Land for purposes of settlement, such as the German authorities desire to conquer in the interest of resettling an industrialized people on the soil, is not to be had in France-at least certainly not to an extent which seems necessary to the National Socialists. This crushing of the West is, in fact, not to

* As the translations of this work published abroad differ in certain respects from the original, it has been found best to give literal translations of the first German edition: Adolf Hitler : Mein Kampf, unabbreviated German edition, published by Franz Eher, Munich, I934. The page references appended to this and future quotations apply to the above first German edition. 


\section{$I \mathcal{N} T R O D U G T I O \mathcal{N}$}

be regarded as an end in itself, but, as the author of Mein Kampf stated clearly even before he seized power, this crushing of the "mortal foe" is the indispensable primary condition for securing a free hand in the East and South-East. This free hand in the East, however, is the real and true aim of National Socialism, and Hitler himself justifies as follows the necessity of a "definitive active settlement with France in a final decisive struggle, conducted on the German side with the greatest aims":

Only then will it be possible to bring to an end the eternal struggle-in itself so barren-between ourselves and France, under the assumption of course that Germany really sees in the destruction of France merely a means of being able to give our people at last a possibility of expansion at another point.

What is meant by "possibility of expansion at another point" needs but little elucidation, and the entire policy of the régime, particularly since 1934 and after the conclusion of the treaty between Paris and Moscow, shows with perfect clarity that National Socialism is concerned, first and foremost, to separate the individual victims of its expansion policy in good time from one another in order to dispose of them one after the other. That the order of doing so is not the same as it was under Bismarck's policy must not mislead us. For this order corresponds to the particular strategic and military conditions of the German position today, a position which did not make it appear expedient to Hitler, before his accession to power, to adopt Bismarck's method of first reducing Austria in order then to take up the decisive struggle against France. Today Russia is the gravest foe, and to crush Russia is not to be thought of unless France or her allies can be either overcome or forced by violent pressure into neutrality. 
In more than one point National Socialism has deviated from its original programme, and even if it can be rightly maintained that the most important principles of the conception have been upheld in truly monomaniac fashion, it must nevertheless be remembered that even the German régime of today is bound by conditions as they exist for the moment. It cannot be denied that these conditions have fundamentally changed since the Nazi seizure of power, and that consequently a rigid adherence cannot be expected to those principles of foreign policy and strategy that were laid down during the period prior to that seizure of power. Germany's old "Push South-East" has since the beginning of 1935 come more and more to the front, so that frequently one really has the impression that the main orientation westwards has been completely abandoned. A closer inspection of this "Push South-East", however, is likely to show that there is no question of an abandonment of the original conception, but that it is rather a matter of variations which have become necessary in the interest of the changed political and economic situation of Germany herself and of Europe.

This "Push South-East" was from the very outset one of the most important and indispensable elements of pan-Germanism and especially of the German policy of expansion under the Hohenzollerns. In order to understand its extraordinary significance for the entire European development within the scope of presentday German imperialism it will be essential, before proceeding to present a picture of the South-East European penetration policy of the Third Reich, to give a brief historical survey of this South-East policy under the Hohenzollerns and under the Weimar Republic. 


\section{Part One}

\section{The Historical Roots of the German Push South-East}





\section{Chapter I}

\section{HOHENZOLLERNS AND HABSBURGS}

T. G. Masaryk, who in his writings and especially his New Europe has most aptly formulated the problems of pan-Germanism, justly emphasizes the fact that Lagarde, the leading philosophical and theological exponent of pan-German ideology, designated Austria's relation to Germany as that of "a German colony". In actual fact the Peace of the year I 866 which in some measure, it is true, spared Austria despite her defeat, but at the same time excluded her in advance from the Germany to be founded later, marks the inception of a policy that aimed at utilizing the Austro-Hungarian monarchy under the Habsburgs as an instrument of German expansion to the South-East.

The alliance made in 1879 between the German Empire and Austria-Hungary represents the beginning of the realization of this policy, and Bismarck himself stated, in one of those voluminous memoranda which at that time he sent to the Emperor Wilhelm I, that "the German Empire must never allow itself to remain isolated on the European Continent between Russia and France alongside an Austria-Hungary overthrown and abandoned by Germany. Germany must thus so act even without reciprocity as if she possessed an alliance."

In the Great War the German historian Oncken stated that in this formula ("even without reciprocity, 
even without an alliance") an absolutely definitive orientation had been adopted that could hardly have becn more sharply expressed. Germany needed the Habsburg power as an indispensable instrument for carrying out her South-East expansion policy, and while the German poet Ernst Moritz Arndt, in 1840, composed the following verses so characteristic of the All-German, that is pan-German, * ideology, then as yet so nebulous :

Let the watchword be : to the Rhine, o'er the Rhine,

Let all Germany pour into France,

since 1866 there appeared under the influence of the conception laid down by Bismarck and the Hohenzollerns a swing of the expansion-thrust towards the South-East, while on the West front the only effort made was to cover the flank as against France and England.

The desire to secure a free hand in the East and South-East remained the sole decisive main tendency in the pan-Germanic trend of German policy since the victory of Prussia over Austria. That desire determined not only the German-Austro-Hungarian alliance of 1879 and the policy of Wilhelm II during the Balkan Wars, the Morocco conflict, and the Great War, but also Hitler's policy after the complete seizure of power by this Dictator, who was, it is true, Austrian-born, but is none the less for pan-Germanism a characteristic German figure.

It must be conceded that at various stages during this long period from 1866 up to today the impression could frequently be gained that France and the occupation of Western territories was the real goal of pan-

* The expressions "All-German" and "pan-German" are subsequently regarded as synonymous. 
Germanism, while the South-East questions were thrust into the background. In reality these deflections or this apparent abandonment of the basic pan-German idea were almost always intermezzos, at the close of which it turned out that the real line had in no wise been deserted, but that, in the interest of this imperialist thrust-always regarded as of such vital importancein an Eastern and South-Eastern direction, and in the interest of preparations for it, attacks had to be directed towards the West.

These temporary thrusts westward may best be designated as offensives to relieve other parts of the front-offensives designed from a political, military, and, last but not least, psychological angle to divert the attention of world public opinion and of the reserve forces opposed to pan-Germanism from the real aims of pan-Germanism, that is, from the German push South-East.

It would of course be a dangerous historical and political error to attempt to draw from the fact that the real goal of pan-Germanism is expansion eastwards the conclusion that that movement is a menace merely for the countries of the East and South-East of Europe, while those in the West have nothing to fear from it. Bismarck, Wilhelm II, and Hitler have, of course, more than once attempted to exploit this dangerous illusion in their propaganda. In reality, as will later be proved, there can be no doubt that pan-German ideology was, and is, quite clear on the point that the actual great expansion in the direction of Eastern Europe and the Near East, that is the threat to the Slavonic nations, to the British and French colonial power, etc., can only have prospects of success if the dangerous foe in the rear-the democracies of Western Europe-have been 


\section{GERMANT PUSHES SOUTH-EAST}

so thoroughly crushed in advance that in their impotence they can no longer stand in the way of the imperialistic advance of Germany in an easterly direction.

In this connection one recognizes the significance of the thesis propounded by Hitler in Mein Kampf that the chicf foc, against whom all forces must be concentrated, is France. In reality, Great Britain, whose friendship Hitler has again and again sought in order to isolate France, comes in here. A superficial view of the policy pursued by the new pan-Germanism might really lead to the conclusion that a change had taken place in this connection compared with German policy in the Great War. This, however, would be a dangerous illusion. The Roman motto of divide et impera adopted by the pan-Germans - a motto which, it is true, suffered fearful shipwreck in I9I4-is today as determinant for the pan-Germanism of the Third Reich as it was in the days of Wilhelm II. It lies concealed under the cover of all kinds of slogans, as in particular under that of "bilateral treaties", known elsewhere as "gentlemen's agreements". Their object is always the same, namely the elimination of the single opponent while avoiding the danger that at the decisive moment some third party will hasten to the help of the attacked contractual party, who had deemed himself secure.

This recipe for bilateral treaties was early made use of by Bismarck on the establishment of the North German Union and later on that of the German Empire. It can be traced again and again in numerous variations in pre-War policy, during the Great War itself and in the partially successful attempts made by the Third Reich. To this point we shall also return again later. 
If we now first consider the pan-German policy pursued in the preparation for the Great War as expressed in the relations between the Hohenzollerns and the Habsburgs, the rôle played by old Austria and the Habsburg dynasty in the play arranged by the Berlin-managed pan-German policy cannot be better characterized than is done by T. G. Masaryk in his New Europe :

The Habsburgs, who ruled long over Germany, carried out German policies, and threatened equally the Slav East and South; they oppressed the Czechs and Slovaks, annexed a large part of Poland, pressed against the Jugoslavs, Rumanians and Italians. The Germans, like the Mongolian Magyars, effected a reconciliation with the traditional enemy of Christianity, Turkey, against the Slavs.

The pan-German programme of a uniform identification of the Germans with the imperialist aim of world dominion, mainly based on the right of the strongest, was, in fact, the leit-motif of the policy pursued by Germany towards Austria. There can be no doubt that the Hohenzollern Power did not aim in the Great War at a sharing-up of the booty with the Habsburgs. In Berlin it was realized after the Peace of 1866 , and still more after the Treaty of Alliance of I 879 , how vast were the difficulties which the Austro-Hungarian Monarchy had to overcome, and preparations were therefore made for taking up the heritage of the Habsburgs in Central and South-East Europe. For this purpose a strengthening of the position of the Habsburgs in their own Empire was of course necessary in order to make a useful instrument of war out of Austria-Hungary.

It is of itself in conflict with all historical reason and all political logic that an Empire that had to struggle against such extraordinary difficulties of a national 


\section{GERMANY PUSHES SOUTH-EAST}

character at home should undertake schemes of aggrandizement that meant the conquest and incorporation of further non-German nations. Berlin nevertheless prompted the Habsburgs to such a policy, and whenever the Vienna Foreign Office showed disinclination in this direction the Northern neighbour did everything in its power to set on foot such an expansion on the part of Austria to the South-East. The most important lure applied in this case was the promise of imperial German aid in support of the ambitious Austrian foreign policy.

Today there can no longer exist any doubt that this game which Berlin played with the grievously sick Austria-Hungary was one which exclusively followed the line of pan-German policy, and that with terrible cold-bloodedness Germany reckoned on the probability of the destruction of the Dual Monarchy by the Great War. Austria was regarded on the one hand as an ally, on the other hand as an estate about to fall to the heirs.

At the stage in which pan-Germanism finds itself today, it can be booked as an advantage from the angle of the historian that now and then the truth comes to the light regarding the opinion that not only today but-unexpressed, of course-even at that time was held in Berlin concerning Germany's own position and the actual strength of the Habsburg monarchy. Thus Othmar Krainz in his Hexenkessel Donauraum, which appeared at the end of 1936 and is written wholly in the sign of a National Socialist policy directed towards South-East European expansion, has to concede that the collapse of the Habsburg monarchy was a historical necessity. Among numerous attacks on the policy of the Central and Eastern European national States anct their alleged incapacity for self-determination one finds the sentence : 
The Habsburg art of government in a vast empire of 5o nillion inhabitants belonging to twelve nations had for decades become more and more a failure.

It was thus a State about whose incapacity for continued existence the pan-German circles of Germany and Austria-Hungary itself no longer had any doubt that was driven to a policy of continuous provocation of the small Central and South-East European nations living within and without its borders. While the struggle for a settlement, an Ausgleich, between Vienna and the Czechs, the Poles, and others never ceased, and an atmosphere of ever-present tension-and with it the feeling of impotence of the Vienna Government to meet any case of grave decision-was created, Berlin pushed Vienna forward to a more and more aggressive Balkan policy, the natural consequence of which, among other things, could only be that the Slavs inside and outside the monarchy drew closer and closer together.

Germany, at this stage of immediate readiness for war, avoided as far as possible giving any cause for a conflagration herself, for there was a fear that in this case there would be doubt about Austria's fulfilling her duty as an ally. The advance towards the SouthEast along the line of the Hohenzollern policy should, and must, take place as a result of Austria-Hungary's finding some ultimate and serious opposition on the path of the foolhardy Balkan policy in which she was encouraged by Berlin.

What echo this conception-which later led to the dismemberment of the Dual Monarchy-found in the minds of pan-Germans, not merely in Germany but also in Austria, is best revealed in the sentences in which Adolf Hitler describes the impression which the Sarajevo assassination made upon him at the time: 


\section{GERMANT PUSHES SOUTH-EAST}

What a man wants, that he hopes and believes. The vast majority of the nation had long been sick of the eternally uncertain state of affairs; so it was only too comprehensible that there was no longer any belief at all in a peaceful settlement of the Austro-Serbian conflict, and that a final settling of accounts was desired. But $I$, too, was one of those millions.

Hardly had the news of the murderous attack become known in Munich when two ideas flashed into my head : first, that war would at last be inevitable, and then, that now the Habsburg state would be forced also to keep the treaty; for what I had always feared most was the possibility that Germany herself might once, perhaps on account of this very alliance, come into some conflict, without Austria's having been the direct occasion, however, so that reasons of internal politics would rob the Austrian state of the initiative to back up its ally. (Mein Kampf, p. 177.$)$

In order to understand the pan-German sentiment embodied in these sentences, as well as the conviction which was very widespread, especially at the outbreak of the War, that Germany must unquestionably make use of the Habsburg Empire for the purpose of carrying out her imperialist thrust in an Eastern and SouthEastern direction, it is essential to make a closer investigation of the development of the pan-German idcology under the Hohenzollerns and particularly Wilhelm II.

Following the more or less fantastic expressions of pan-Germanism by Fichte, Arndt, and Jahn, the lastnamed of whom demanded the centre of a new panGerman Empire "between Genoa and Memel, between Trieste and Copenhagen, between Dunkirk and Sandomir", Clausewitz brought forward an already carcfully-thought-out modern strategy for the establishment of such an empire, and Dietrich von Bülow de- 
GERMANY PUSHES SOUTH-EAST manded the recognition of two principles as the most important primary condition : first, the principle that only offensive wars could be successful, and secondly the conviction that small states are always doomed to extinction.

The outstanding aggressive character of pan-Germanism thus found unequivocal cxpression even before the actual pan-German movement set in. It was a mentality which, it is true, was given now and again a philosophical and generally scientific frame, but which in its real aim was directed only towards the acquisition of greater power through territorial aggrandizement.

R. W. Seton-Watson, in his fundamental work on pan-Germanism, German, Slav and Magyar, describes the pan-German plan as having three stages. The first stage he rightly sees in the proposed establishment of a so-called "Mitteleuropa", a vast state of 130 to 160 million inhabitants, as an economic and military unit. The second stage consists in the achievement of the link designated by the slogan of "Berlin-Baghdad" which is to extend the political and economic influence of this great State-entity to the area lying between Hungary and the Persian Gulf. The third stage, for which, however, the establishment of this gigantic colonial empire is an indispensable condition, is best designated by the word "world-power", that is, dominion of the sea after the great naval powers, England, U.S.A., and France have been laid low.

History shows us how the Hohenzollern Empire, making ample use of the indispensable Austria-Hungary as the very tool for this purpose, did its utmost to attain the first two aims. In view of the thoroughgoing imperialist attitude of the Hohenzollerns, especially of Wilhelm II after the departure of Bismarck, it is not 
GERMANT PUSHES SOUTH-EAST surprising that, under the influence of the pan-German programme, the third goal was aimed at even before the first two far-reaching aims had been achieved, and that the incvitable conflict with the Western Powers arose- a conflict which, in the first place, does not fit in with the real conception, just as Hitler today takes credit for the fact that he limited himself in advance to the Continental ideas.

But in this connection, too, it is seen that appetite to some cxtent grows with eating. Later, in reviewing the foreign policy of the Third Reich, it will be seen that the original intention never again to force the German nation into opposition to England and to abandon colonial dreams in favour of expansion at all costs on the Continent had to be given up.

The will to reconcile himself to a certain self-denial in respect of territorial gain in the East and South-East of Europe may in Hitler's case have been originally as sincere as in the case of Wilhelm II and under Wilhelm I and Bismarck. It is by no means mere chance, however, that pan-Germanism, recognizing that it cannot so easily attain the first, relatively limited, aims of Continental expansion as it originally imagined, always begins to work ahead towards the alluring goal of "world-power". It realizes that it cannot acquire the "free hand" in the East and South-East which it formerly hoped to attain through the support of the Habsburgs and now by the aid of the German Minorities and the Berlin-financed fascist groups in the SouthEastern nationality states, without meeting natural opposition on the part of the Western Powers. It is a psychological peculiarity of pan-Germanism that at this point it does not take the course-in itself the logical onc-of making a reduction of its Continental pro- 


\section{GERMANT PUSHES SOUTH-EAST}

gramme, but that it goes forward over the unattained goal of South-East European territorial gains, and thus accentuates the opposition to the Western Powers which it actually ought to avoid.

Wise and far-seeing English historians and politicians have always perceived the connection between these things. They have protested emphatically against the temptation to allow Germany free hand in the SouthEast for the purpose of apparently fortifying their position in Western Europe and on the high seas. Seton-Watson thus expresses one of the most important lessons of the Great War :

If we are right in regarding sea-power as the key to victory, it is none the less true that the extension of German land power will be the prelude to a fresh attempt to challenge our security on the sea. (p. 125.)

If one regards the relations of the Hohenzollerns and Habsburgs from the angle here indicated of Germany's pre-War plans of expansion to the South-East, which were proclaimed under the slogan of "Mitteleuropa" and "Berlin-Baghdad", the political literature emanating from pan-German circles in the last few decades before the outbreak of the Great War provides us with ample material for an understanding of the mentality which was not only tolerated but largely encouraged by the Hohenzollern dynasty and became, as it were, anchored in the German nation. In his booklet, Berlin-Bagdad-Neue Ziele mitteleuropäischer Politik (New Aims in Central European Policy), Karl von Winterstätte outlined his programme approximately as follows :

A new land of peasants and farmers, a great economic area, the salvation of the German element in the Danubian 
GERMANT PUSHES SOUTH-EAST monarchy, the union of all Germans, a free way to the South-East, protection of the non-Slav races in the SouthEast against pan-Slavism-in brief, Berlin-Baghdad will be created.

In justification of this programme he declared that upon the carrying-out of this scheme depended the future of the German race.

If we fail there is no other habitable land in the world that the Germans can hold sway over, and it will be our fate to be mere dung on the earth (Kulturdünger).

George Reimer, in his Pangermanistisches Deutschland (A Pan-German Germany), that appeared in 1905 and which in principle rejected the rights of the small nations to existence and every right to the use of their own languages, speaking of Austria-Hungary says :

This chaotic medley of races is situated between three States that have a right to a future of their own : Germany, Italy, Russia.

He adds that for the moment one may content oneself with the phrase that Austria-Hungary's existence is a political necessity. When, however, the decisive moment came it was the duty of him who had a right to live to take that right from him whose life was just one long sickness. The loftier morale of this world of new values demanded that two strong men should rather do wrong to a weak third than give up their own promising development in favour of that third, who is sick all the same.

In this book, which attracted much attention at the time, it is emphasized that Germany alone has a right to supremacy. A French world empire was impossible and a German one must arise. The smaller nations must yield, on the one hand because they were partly 


\section{GERMANT PUSHES SOUTH-EAST}

of German blood, and on the other because they represented territorial and political obstacles in the way of German development. Germany's aim was thus, first, a Germanic racial Empire under the German nation, a world-dominion of Germanic races under the hegemony of the German nation ; secondly, the successive Germanization of all the races of Scandinavia and the Netherlands ; and, thirdly, the destruction of the non-German races, either through Germanizing them or driving them out.

Thus, according to Reimer, the Czechs, Slovaks, Slovenes, and Poles are to be eradicated, and on the other hand France reduced to impotence. In the worst case, France could be allowed a natural autonomy in so far as such a status could be brought into harmony with the dream of a German world-dominion. From the much-discussed and much-read books of this kind, published in great numbers at the outset of the century, it can clearly be seen what rôle the ever-expanding pan-German ideology and the policy of the Hohenzollerns proposed to leave in reality to the Habsburg monarchy and the nations domiciled therein. Slogans like that of "Nibelungen-Treue" fade into the background under the impression of the real trend of thought here revealed - a trend of thought that ever and again emerged in many nuances to the effect that the Habsburg Empire, recognized as rotten within, was not to be regarded as a real ally but rather as an instrument for the pan-German thrust to the South-East.

In the Great War itself, as the weakness of the Habsburg monarchy became still more apparent, Ernst Köhler openly declared in his Der neue Dreibund (The New Triple Alliance) that Austria must exist for the sake of Germany, and that it would be Germany's 
task after the War to convert old Austria into a new German-Austria. In Naumann's well-known Mitteleuropa, for long, and especially during the War, regarded as the standard exposition of German policy, the author demanded not only "a united nation of brothers", but he also declared that Germany must either give up the idea of ever becoming a world dominion or must organize a Central Europe under her own lead as an economic entity. Here again we find the idea that the days of the small states are numbered.

One frequently finds in the German histories of the post-War period during the epoch of the Weimar Republic the standpoint upheld that these pan-German views, culminating in the exploitation and finally the dismemberment of Austria-Hungary, accompanied by the extermination of all the not purely German peoples living in the Habsburg monarchy, represented the ideology of outsiders, and that the entire pan-German literature had nothing to do with the official policy of Wilhelm II and his Cabinets. This is, for example, the leading idea of Rudolf Nadolny's Germanisierung oder Slavisierung, a book published long after the end of the War as an answer to Masaryk's New Europe, in which the author goes so far as to take up the defence of the entire policy of Wilhelm II. After slurring over the mistakes of German pre-War policy, which, according to Nadolny, consisted only in the fact that Wilhelm II in his efforts in the sphere of foreign policy had overestimated the strength of Germany, the author declares :

He was a Prince of Peace, inspired with the great ambition to develop and expand his Empire by peaceful means.

In what stark contrast such assertions stand to the real facts of history, and how closely the pan-German 
mentality as indicated by the examples given above corresponded to the views of Wilhelm II, especially in the question of the relations to the Habsburg monarchy, will be clear to all who have read with any attention the speeches on foreign policy delivered by the Hohenzollern Kaiser after his accession to the throne, or indeed while he was yet Grown Prince. Even before he became Emperor he was already in close contact with all panGerman circles who did not, of course, come to the front until after Bismarck's resignation. The Deutsche Schriften of Lagarde, as well as the essays and treaties by David Friedrich Strauss, which have a sharp antiSemitic undertone, refer again and again to the duties and tasks for which the then Prince Wilhelm was to fit himself as the future German Emperor. In one of Strauss's letters to Prince Wilhelm of the year 1886 we read :

A small Germany can only be regarded as a perhaps inevitable and necessary stage on the way to a Greater Germany, just as the North German Federation was but a step towards the present German Empire.

Here, too, it is already stated that the real mission of the German race lies in colonization, and that the nonGerman areas of Austria-Hungary and Germany must be Germanized, or, better still, "Prussianized". Strauss explains to the later German Kaiser explicitly that the Hungarians, the Cizechs, and other such nationalities under the sceptre of Austria are only a burden, but that they might serve as "mortar" for a superior race. Typical of the inferiority complex of pan-Germanism as a whole-a feeling of inferiority that is concealed behind proud declarations of the superior worth of Germandom-is also the passage :

All of them [Hungarians, Czechs, Jews, etc.] hate us because they know that our life is their death, and that 
without us there is no intellectual life for them. Nevertheless they refuse to admit our superiority.

The relationship between the Hohenzollern and Habsburg Empires-so often misconceived and looked upon as an alliance of two equals - was perhaps by no one so clearly understood or so aptly expressed as by T. G. Masaryk in his characterization of the Habsburg system. Masaryk's remarks in his New Europe are in many respects as applicable to the conditions existing after I933 as they were to the pre-War period, and in that work the founder of the Czechoslovak Republic says :

In its historical perspective the German "Drang nach Osten" may be looked upon as an attempt to solve the old Eastern Question. After the Greeks in Europe, Asia and Africa, after Rome, after Byzantium, after the Franks and the German-Roman Empire, after the Crusades and after Venice, Prussia, having restored the Empire, continued the task of uniting Europe with Asia and Africa and organizing an Old World under a single control.

In the German philosophy of history, in German policy, pan-Germanism is, as a closer study again and again shows, the leit-motif. It is embodied in its ultimate aim, in the gathering together as a totality all those who pertain to the German race-the conception of nation and race being at the same time subject to manifold interpretation and continual change. This gathering together, which is to comprise not merely the actual Germans, but also the Germanic races generally in the broad sense, is to be accomplished through the attainment of world-dominion and by methods of the strong hand.

The creation of a new Central Europe under German hegomony and the incorporation of Asia and Africa via 
GERMANT PUSHES SOUTH-EAST the East and South-East has also been, and still is, regarded as the primary condition and the immediate objective of this aspiration. The first and most serious opposition is presented by the Slav nations, the subjection of whom, therefore, in the whole pan-German ideology is an essential condition for any further expansion. The relation of the Hohenzollern Empire to the Habsburg monarchy was in its fundamental tendency determined by the endeavour of Berlin to utilize the Habsburg Empire for the subjection of the nations of the South-East, especially the Slav nations.

In this connection it must have been obvious that an empire which, like Austria-Hungary, contained so many non-German and especially Slav peoples itself and suffered from countless internal weaknesses, ran the risk, in being exploited as vanguard of the German "Push South-East", of going to destruction as the victim of German imperialism. The Hohenzollern Empire, under the continuous influence of pan-German ideology, not only reckoned with this risk, but regarded the inevitable collapse of the Habsburg monarchy-whether it happened sooner or later-as a further step towards German expansion to the South-East.

The Habsburg Empire has disappeared, but panGerman ideology remains. The German thrust to the South-East has only in appearance been held up through the collapse of Austria-Hungary and the loss of the Great War. The south-easterly advance today is directed against the small states and nations. They are today menaced in like manner as were the nations of the old Danubian monarchy; and the heirs of the Hohenzollerns, who have taken over their ideology, menace today, as before the War, not only the SouthEast, but with it also the peace of all Europe. 


\section{Chapter II}

PAN-GERMANISM IN THE ORIENTAL QUESTION AND THE BALKAN WARS

IN order to complete the picture of the historical effects of all-German ideology and its leit-motif of advance on the Berlin-Baghdad line, it must be recalled that-and for what reason-pan-Germanism was interested in the conservation of the moribund Habsburg monarchy and also of the Ottoman Empire.

Like Austria-Hungary, Turkey in Europe was, until the Turkish nation retired to within its natural boundaries, thereby creating an entirely renewed and vital state, a "colossus with feet of clay", a giant kingdom within which a number of young and striving nations was ruled by a weak and parasitic ruling class. PanGermanism's interest in the maintenance of this moribund state lay on the one hand, as in the case of the Habsburg Empire, in the desire to use the former Turkey as a medium for the exertion of influence and for indirect rule of the Balkans and Near East.

On the other hand, the main obstacle in the path of the German penetration south-eastwards and of the plan of forming a giant Central and South-East European Empire under Prussian hegemony was, as has been shown, the youthful vigour of the small nations, particularly the Slavonic ones. Where these races lived under Habsburg rule, Vienna was used to keep them in submission and to assure the Germanic predominance. 
In addition, the Habsburgs provided the Hohenzollerns with an important instrument for furthering panGerman expansion towards the Balkans, though at the risk of a further weakening of the Danube state.

Finally, the pressure of Islam and the constraint of Ottoman rule was needed, on the one hand, to prevent the independent liberation of the Balkan Slavs, or at least to make it more difficult; on the other hand, to stop the advance of Russia, the only Slavonic great Power which was capable and desirous of expansion; for such advance by Russia would seriously have endangered the German push south-east and threatened the line Berlin-Baghdad, along which pan-Germanism planned to advance.

These considerations led to pan-Germanism's interest, traceable during the whole of the second half of last century and right up to the Great War, in keeping the "sick man on the Bosphorus" alive at all costs, in opposition to all natural development and contrary to the interests of the Western Powers, as well as to the rights of the small Central and South-East European nations to existence. Berlin's policy, entirely under the influence of the pan-German ideology adopted by Wilhelm II, considered this interest so strong that even the sensellessness of an alliance with this second dying empire was not too much.

A question often put after the defeat of the Central Powers in the Great War was why Imperial Germany allied itself to two states politically and militarily so lacking in vitality. The answer to this question is that the policy of maintaining these alliances is the inevitable consequence of the pan-German ideology and of the "Push South-East".

Although names, men, and methods changed in the 
meantime, the idea of expansion south-eastwards determines the policy of the Third Reich today in the same way as it did at the time of Wilhelm II. Mistakes repeat themselves, as the premises remain in principle the same.

For this reason Hitler's foreign policy can be understood only by considering its historical connections, not isolated, even though Hitler himself expressly emphasizes, as he does in his book Mein Kampf, that he has made a fundamental change in the foreign policy of Bismarck and Wilhelm II. This statement, it should be emphasized here and now, is particularly important with regard to the colonial problem. When Hitler says that to gain England's friendship he will never seek to acquire colonies, but will satisfy himself with the realization of the pan-German idea in its narrower form, i.e. with a union of all the German peoples on the Continent, it will be seen from the history of the pan-German ideology that the "Push South-East" must necessarily and inevitably lead to a conflict of interests and finally to a decisive struggle with the Western Powers, particularly Great Britain.

The economic and political obstacles in the path of this penetration south-eastwards still make it impossible for onc to reconcile oneself to either the first point of the pan-German programme ("Mitteleuropa") or to the second ("Berlin-Baghdad"), in consequence of the impossibility of carrying them out, and one always nas to come back to the third claim ("world-power"). For innumerable reasons, this claim is today still less realizable than before the Great War; now, still more than at that time, it carries with it, as inevitable consequence of the pan-German ideology, the germ of one of the most terrible defeats in German history and 
GERMANT PUSHES SOUTH-EAST of a European catastrophe. But this must be discussed in detail later.

It will be evident how strong was Berlin's interest in the maintenance of the moribund old Ottoman Empire, and how pronounced the conflict of interests between Berlin and London in the Oriental Question had become even before this time, if we recall that when Lord Salisbury, during a personal discussion in June 1895, offered the Kaiser a division of Turkey, he received a categorical refusal. At this point England's alienation from Germany's policy starts to enter a very dangerous stage. Bismarck foresaw this development when, after his dismissal, he recognized that a conflict of interests with England was the inevitable consequence of Wilhelm II's policy. In a conversation with Heinrich von Sybel, as early as I893, he said, speaking of Great Britain :

She considers herself invincible and believes she does not need Germany's help. She considers we are not her equals and would conclude an alliance with us only under conditions which we could never accept. When we conclude an alliance, we must be the stronger party.

Germany's pre-War policy of trying to entwine Roumania and Turkey in the complex of treaties between the so-called Central Powers should also be mentioned in this connection. This attempt, however, failed when it became necessary for the alliance concluded to prove its worth in time of need.

Here, too, one clearly sees the attempt of Berlin's politicians to get a stranglehold over the Slavonic nations within and outside the Habsburg Empire. When they saw in time that it was in conflict with their own interests and their own strength, as in Roumania 


\section{GERMANT PUSHES SOUTH-EAST}

(and in Italy, too), at the decisive moment they did not keep the treaty. On the other hand, it became clear that for the Powers which, like Vienna and Constantinople, thought to survive the crisis of the Great War by virtue of maintaining the alliance with Germany, it was just this connection with pan-Germanism which finally sealed the fate of these states.

With regard to the German-Turkish alliance, which was to prove its value in the Great War, it must constantly be borne in mind what was the condition of Turkey in Europe, for which Berlin destined such an important rôle in protecting the Berlin-Baghdad line. According to the figures given by Marriott in The Eastern Question (p. 449) the development of the territory and population of Turkey in Europe since about the middle of last century gives the following instructive picture :

Ottoman Empire in Europe

1857 (after the Treaty of Paris) 1878 (after the Treaty of Berlin) 1914 (after the Balkan Wars)
Territory in square miles

I 93,600

I 29,500

I 0,885
Population

I $7,400,000$ $9,600,000$ I,8g I, 000

The long period during which the Turks scattered over the Balkan Peninsula lived within the boundaries of an Ottoman Empire of their own can therefore be said to have ended by the middle of the nineteenth century. In the First Balkan War, Roumania, which up to 1866 had been subject to the former Turkey, united with Greece, Bulgaria, and Serbia to wrest their independence from the Turks. Bulgaria then received most of the booty, the Dobrudsha (now Roumanian), South Maceclonia (now Greek), with access to the Egean, the present Southern Serbia and Northern Macedonia. The consequence of this inequitable 38 
distribution of the spoils was an alliance between Greece, Serbia, and Roumania against Bulgaria in the Second Balkan War, during which the recently defeated Turkey regained Thracia and Adrianople.

Bulgaria, which in consequence of the unfortunate outcome of the Second Balkan War had lost to Turkey and its former allies the territory it had acquired in the First Balkan War, seemed to Germany on the outbreak of the Great War a valuable ally lightly to be won. On the one hand, it had claims for territorial revision resulting from its defeat in the Second Balkan War, and on the other hand this country, which had clearly shown its prowess in the First Balkan War, was thought worthy to be a vital point in the line of expansion leading south-eastwards from Berlin via Vienna and Budapest to Constantinople and Baghdad.

How little this attitude to Bulgaria has changed, even after Hitler's rise to power, is clearly visible from the literature devoted to south-east problems in recent years, just as the conception of the Third Reich, as will be shown later, is closely related to that of the BerlinBaghdad prophets of the Hohenzollern period. In his book Hexenkessel Donauraum, which is recognized as authoritative in National Socialist circles, Othmar Krainz names one of the most important chapters "Balkanherzstück Bulgarien" (Bulgaria, the Heart of the Balkans). Apart from the phrases newly coined by the Third Reich, such as the statement that "the peasant population of Bulgaria is racially on a high level", it is clear that-and why-just as at the time of the Great War, particular weight is laid on the penetration of Bulgaria, where not only most of the foreign trade has been seized upon, but also a strong National Socialist party under the leadership of Zankoff is maintained. 
In reality the alliance with the Ottoman Empire and Bulgaria under Wilhelm II was just as unfortunate and, for the countries in question, as fateful, as the use of the Habsburg monarchy for furthering the imperialistic plans which Germany followed in the SouthEast under the slogan "Berlin-Baghdad" during the Great War. The German Balkan policy was also doomed to fail, because co-operation with the Bulgarian allies naturally encouraged Roumania, Greece, etc., in their anti-German policy just as much as the Hohenzollerns' alliance with the Habsburgs inevitably awoke the opposition of the Slav nations in the Danube monarchy and the alliance with the Sultan that of all the nations and tribes which, like the Balkan States, wished to shake off the century-old Turkish yoke.

Of course, conditions today have changed in many respects, and the position of Bulgaria, which in 1937 achieved a rapprochement with Yugoslavia and the Balkan Entente, giving up its Irredenta, which up to then had been continually claimed, can no longer be easily compared with the position of the land just beaten in the Second Balkan War, which allied itself with Germany in the Great War, thereby only aggravating its position. But, apart from this and other similar details, it is astounding what similarity can be traced between the south-east policy of the Third Reich and that adopted by Wilhelm II in the Great War.

A particularly noticeable parallel is the endeavour which can be traced once more today to secure the south-east line of advance by winning over the Mohammedan states and nations of the Near East. Modern Turkey is, it is true, at present not a suitable medium for the furtherance of the German plans of expansion, but all the more attention has therefore been paid to 


\section{GERMANT PUSHES SOUTH-EAST}

winning over the Arabs. The policy of waking the whole of Islam to revolution, systematically followed by the most risky and expensive methods, fully utilizing anti-Semitic and anti-French propaganda, is, of course, just as at the time of Wilhelm II, latent with the danger of a serious conflict with England. Now, as then, Berlin requires the declaration of a Holy War, as it is thought that the "Push South-East" can in this way best be prepared and assured.

Whether the New Germany's policy in this respect can be successful will be investigated in detail later. At this point it should, however, be stated that the BerlinBaghdad policy of the Hohenzollern Empire, born of the pan-American ideology, provided the strategic, economic, and even cultural leit-motif which led to the alliances with Vienna, Constantinople, and Sofia, and finally to the attempt at realization of these plans of conquest in the Great War.

An important link in Wilhelm II's Berlin-Baghdad policy was the alliance with Islam. It is true that German Imperialism's desire for colonies played no small part even before the Great War, as did the wish to threaten England in its supremacy on the seas, the nerve-system of the Empire, in stimulating panGermanism's lust for power. But the real meaning of the Hohenzollern policy was not a boundless dream of empire, or naval supremacy in England's place by vanquishing the British fleet, for which, as can be seen from the archives and even the very pan-German literature of pre-War days, they felt themselves at heart to be no match. The real aim of pan-Germanism was then, as it is now, what is described as the "Drang nach Südosten", the acquisition of territory rich in raw materials, good farming land, the union of all the 
German tribes in East and South-East Europe under Prussian leadership, and at the same time the displacement or oppression of the non-German and particularly Slavonic nations.

This aim could only have been reached by force, and by warlike methods; on this realization is based the recognition that the push South-East, which has always been regarded by pan-Germanism as its real historical task, had to lead to war. This war, rendered inevitable by the push South-East, and finally brought about on Berlin's initiative, could never, however, be localized by limiting it to the subjugation of the small South-East nations by pan-Germany. For these "little nations", which form an unbroken chain from the Baltic to the Adriatic and Egean, are a factor whose significance in world politics was then, as now, much underrated by the pan-Germanists. Their importance lies above all in the fact that their subjugation by panGermany would inevitably bring the latter into serious conflict with the Great Powers, particularly Great Britain, France, and Russia, which would be entirely insoluble by peaceful methods.

Just as the Mediterranean is not only a traffic route, but also the maritime life-cord of the British Empire, so this chain of little nations stretched between the two Great Powers Germany and Russia is strategically and politically an indispensable land-route for the British Empire from England itself to the Near and Far East. Its destruction or even break involves for Great Britain the necessity for military intervention just as much as would expulsion from Gibraltar and consequently from the Mediterranean. The pan-German push South-East had to lead to conflict with England and to a world conflagration. In this respect nothing has changed today. 


\section{Chapter III}

GERMANY'S GENTRAL EUROPEAN PROPAGANDA AND THE WEIMAR REPUBLIC

Pan-Germanism's considerable influence on official German pre-War foreign policy, and the propaganda carried out during the Great War, had forced on German public opinion a programme for the reorganization of Central Europe, the main features of which were already sketched out. It is typical of the psychology of the German people that after the failure of similar programmes, which can only be fulfilled by forcible means, there is a very quick change of front. Again and again in German history we find after the collapse of pan-German campaigns for expansion by conquest the endeavour to disculpate the German nation itself from the reproach of such attacks on the peace of Europe, and, where such a guilt is really undeniable, to vent all its own anger and that of the enemies who have successfully withstood the German attempts at territorial aggrandizement on certain persons or small groups.

After the Great War these tactics were repeated in the well-known thesis that the German people were deceived and led astray, that it was entirely guiltless of responsibility for its fate, and that the historical punishment should be reserved for those who had, to a certain extent against its own will, enticed Germany into this adventure. Nearly all the post-War political literature of the first years of the Weimar Republic can 
be reduced to this formula. At most they were willing to accept the historic guilt of Wilhelm von Hohenzollern, but even this less from a feeling of having been deceived than with the intention of emphasizing all the more the peacefulness and democratic nature of the character of the German people.

This development will probably often have to be called to mind-whenever pan-German attempts to torpedo European peace have been shipwrecked, as they were in I9I8. The responsibility of the German nation, which yielded to such a deception, was mentioned then as little and as unwillingly as will probably be the case on similar occasions in the future.

When, in spite of all efforts of the censor, the danger of defeat in the Great War could no longer be completely banished from discussion, in 1917 and 1918 , it was asserted that even the loss of the War must result in no final renunciation in the Central European question. An eminent author like Franz von Liszt, even, concludes his book Ein mitteleuropäischer Staatenverband (A Union of Central European States), which appeared as early as 1914 and demands the realization of the panGerman plan of a union of the entire Central European territory extending to the Near East, all under Prussian hegemony, with the following words, which show clearly that the Berlin-Baghdad plan was not to be given up even after a defeat in the Great War :

And if things turn out otherwise than we confidently expect? If we are finally beaten and reduced to the rank of a second-rate continental Power? Then my words show more than ever the path our foreign policy must tread. Then the organization of Central Europe as a protection against Russia and England will be more than ever the burning question of the immediate future. Then, it is true, Germany will have to be satisfied with a more 
modest rôle in the union. But even then the strength of the coming generation of Germans will nourish the hope of all the states of Central Europe of being able to shake off the double foreign yoke as soon as the day of reckoning comes. Even a defeated Germany is a guarantee of a victorious war and therefore of a permanent international peace. (p. 45.)

Nevertheless, the force of circumstances and the considerable increase in the influence of the Left Parties in German internal politics led the Weimar Republic first to satisfy itself with various attempts to obtain the union of Austria and Germany. After it had become impossible to secure this by way of treaty, the "Anschluss" became an important point in the programme of nearly all the German parties, and with the slow strengthening of pan-German tendencies attempts were made to put it into practice, at first in the sphere of political economy.

In consequence of the decision of the Hague International Court that the German-Austrian Customs Union was irreconciliable with the existing treaties, preference was shown, in view of Germany's situation militarily and internationally, to avoid for the time being the dangerous path, which according to the methods of the Wilhelm period consisted in presenting the rest of the world with a fait accompli. But panGerman circles, which had lain low under the atmosphere of defeat, found more and more adherents, who, it should be remarked, were by no means gathered exclusively around Hitler. From year to year there was an increase in the number of German political, economic, and cultural publications demanding a revision of the peace treaties and an extension of the German sphere of influence in the South-East. 
In this connection it is interesting to note that the language of pan-German post-War literature grew continually clearer and more aggressive. In his book Germanisierung oder Slavisierung (Germanization or "Slavisation"), which its subtitle declares to be a reply to Masaryk's book New Europe, Rudolf Nadolny already attempts a vindication of the German war policy and even of Wilhelm II by advancing the thesis that panGermanism has always been much exaggerated, that the pan-German ideology had no considerable influence on Germany's foreign policy and on Wilhelm II personally, and that pan-German tendencies, where any at all can be found, should really only be considered in the light of a resistance to the much more dangerous and aggressive "pan-Slavism". The attempt is made to keep the acquisitive tendency of pre-War German policy in the South-East as much as possible in the background, and Nadolny, drawing a contrast between Germany and the other great European states, which he reproaches with all kinds of military conquests on a large scale, says :

Germany was peaceful and maintained the status quo. Economic activities and the acquisition of colonies abroad for the labouring and multiplying German nation by peaceful means : these were the aims of Kaiser Wilhelm's policy, and the phrases about the "mail-clad fist" and the "shining weapons" - whether one approves of them or not -were merely in the service of the principle : si vis pacem, para bellum.

It will be seen that the renewed outburst of panGermanism, which had only temporarily been kept in the background, was at first primarily of a defensive character, and that attempts were made to place the panGerman policy of the pre-War and War years, which 


\section{GERMANT PUSHES SOUTH-EAST}

finally led to the catastrophe, in as harmless a light as possible, in order to attribute the really aggressive mentality to the rest of Europe, which had opposed the pan-German attack-for decades so carefully prepared -with such catastrophic results for Germany in the Great War.

The next step on this path was the much-discussed repudiation of the "war-guilt lie". The bellicose mentality of pan-Germanism having been, so to speak, declared a phantom and the malicious invention of the enemy (although it dominated the entire German political literature, at least since the accession of Wilhelm II and up to the end of the Great War, and even now can be demonstrated from innumerable quotations in all manner of formulation), the conclusion was reached that both the defeat in the Great War and the resulting peace treaties represented a wrong done to the German nation.

In view of the highly developed sense of justice in Germany, the most important task of the Berlin politicians must therefore be to right this wrong. To resume military operations in the West was unthinkable, and so the old idea of expansion in the East, and particularly the South-East, came once more to the fore in pan-German propaganda, which now ventured more and more into the open, at first with the apparently harmless slogans: "A new Mitteleuropa", "GermanAustrian Customs Union", et cetera. For obvious reasons the unpopular demand to declare a new and more hopeful war was shunned, and only claims of a cultural and economic nature were advanced, as their exponents were at heart convinced that everyone knew what these really meant. The attempt was made to render this propaganda still more forcible by pointing 
out the removal of the ruling houses of Germany, Austria-Hungary, et cetera, and explaining that in consequence no dynastic interests were opposed to the formation of a new "Mitteleuropa" under Prussian leadership, although they previously had to be considered as a hindrance.

Thus Dr. Albert Maier in his lecture "Grossdeutsche Geschichte" (The History of Greater Germany), which was included at the beginning of a muchdiscussed miscellany published in I 929 by Felix Behrend, entitled Greater Germany, states that the Germans "had fought shoulder to shoulder up to the bitter end", and that this bitter end "wrested from us the storm-proved strength of the Sudetic Germans and the eastern territory inhabited by German stock". Shortly afterwards in the same lecture the statement is made :

The path to our future is free. We have now no longer to accuse dynasties and princes. The destiny of Germany is torn from their hands. The right to decide over the weal and woe of the nation is with the people. We ourselves must now show whether we are equal to our destiny and our freedom, so suddenly acquired. We must at last know what we want, we must want what we-knowingly and consciously-consider to be necessary. (p. 3o.)

In I929, therefore, the Weimar Republic had reached a point where the dethronement of the dynasties which formerly, to their own misfortune, had allowed themselves to be willing instruments in the hands of pan-Germanism, is declared to be a progress towards the pan-German ideal. No great acuteness is now necessary to find out what the author and pan-German circles "want". The publisher of this miscellany, Dr. Felix Behrend, is still clearer in his own article : 
"Deutsche Kulturpolitik" (German Cultural Policy), which is also contained in this work, where he says :

But more than that, before our eyes stands the new demand : the Greater Germany of the future, the common fate and race of the one hundred million Germans, the kingdom of justice and freedom for fellow-Germans even outside of the Reich. (p. 92.)

Both the calculation of the population of this "Greater Germany" and the expression "Volksgenosse" (fellow-German) occur in the political literature of the Weimar Republic more and more often. As early as r930 an anonymous pamphlet was published, entitled Revision in Central Europe, already containing a map of the territories which would have to fall to Germany on such revision. And this revision is almost exclusively limited to South-East Europe. With reference to the "convinced and courageous adherent of territorial revision, Lord Rothermere", the German sphere of influence is extended either by direct union or by the so-called "neutralization" over Bohemia, Moravia, Austria including Croatia, Hungary (which obtains Slovakia), and Transylvania, nearly down to the Black Sea, so that we really meet a new edition of the pre-War panGerman plan of a "Mitteleuropa" reaching from the Rhine to the borders of Asia.

Long before Hitler's rise to power, therefore, a return had been made to the well-known pan-German ideology of pre-War years with its "Push South-East", and the only difference distinguishing this literature published in about 1930 and that of the Great War is seen to be the powerlessness which induces the authors to demand all these changes of boundaries "by peaceful methods" and to banish the words "war" and "force" from their vocabulary. 
GERMAN PUSHES SOUTH-EAST

But even this attempt to avoid the threat of force, at least formally, is soon afterwards abandoned. This last step, which restores pan-German ideology to full power after the intermezzo of the Weimar Republic, is taken by Hitler, who admits openly that the "Greater Germany", extended Eastwards and South-East, can only come to pass after a passage of arms with France "under the supposition, it is true, that Germany really sees in the destruction of France only a means to an end, in order that afterwards our nation may be given the possibility of expansion in another territory".

This finally concludes not only the short period during which, for reasons which need not be recapitulated, the Weimar Republic had to give the impression that pan-German aims had been finally renounced and that the "Push South-East" was a thing of the past; this also marks a temporary halt in the development of the whole pan-German ideology. It is seen here that the pan-German idea, which finally decided the entire German foreign policy for nearly the whole of the nineteenth century, at least for the German Empire under the Hohenzollerns, could only be checked temporarily and in consequence of exterior influence. It was, is, and will continue in future to be the decisive factor of the entire German foreign policy.

It is impossible to understand Germany's foreign policy and to judge it impartially without bearing this pan-German leit-motif in mind. Hitler started where Wilhelm II, when he fled to Holland, had to leave off. From the same conception of Germany's pan-German policy, determined by the "Drang nach Südosten", arises the absolute necessity of a corresponding harmony in the rest of the European concert. Ideologically speaking, Wilhelm II von Hohenzollern is reincarnated in Adolf 
GERMAN PUSHES SOUTH-EAST Hitler. This fact, with all its implications, must be recognized if the pan-German tendencies of the southeast policy of the Third Reich are to be understood and Europe is to be warned of the dangers latent in the "Drang nach Südosten" as one of the most important manifestations of pan-Germanism. 



\section{Part Two}

German South-East Policy under Hitler 



\section{Chapter IV}

\section{OLD AIMS-NEW METHODS?}

HitLer resumed the entire pan-German ideology of the push South-East even before he came into power in 1933. From the old imperialistic thesis of the Hohenzollern Empire, which he adopted in his book Mein Kampf by saying that "only a sufficiently large space on this earth guarantees a nation its freedom of existence" (page 728), there arises for him and all National Socialist politicians again and again the great question : where is this space which the German nation must conquer in order to be able to exist?

Theoretically, there may be said to be two answers to this question. German imperialism could procure this space by colonial conquests in conflict with the Western Powcrs. It could, however, likewise resume the old idea of the push South-East and acquire there, for example in certain parts of Eastern Europeespecially the Ukraine-the land without which, according to the pan-German ideology, it cannot exist.

It will be remembered that Wilhelm II aimed at both these goals, but a careful study of the pan-German tendencies of pre-War times, which have already been outlined here, proves that the conflict with the Western Powers, the struggle for naval supremacy, and, in brief, all that Wilhelm II and the pan-German association included in their programme under "world-power", was merely the necessary outcome of this very panGerman idea of the penetration South-East. 
The democratic states in Western Europe, the U.S.A., and Russia clearly saw, even before the Great War, that this advance south-eastwards must end by seriously endangering their own interests, and that it would serve the purpose better to take timely precaution against the pan-German danger by putting a stop to this push South-East. Despite the fact that in various places in his book Mein Kampf Hitler emphasizes that he is in a way making a great change in the German policy, by abandoning the idea of conquests in the West, and even a colonial policy, in order to gain a free hand in the East and South-East, it would be a dangerous delusion to see in the theses here submitted a real change in the pan-German ideology.

He himself, it is true, declares in his explanation of the Eastern policy in his book :

We hem the everlasting flood of Germans into Southern and Western Europe and turn our gaze to the land in the east. We abandon definitely the colonial and commercial politics of pre-war times and turn to the land policy of the future. (p. 742.)

At the same time, however, he emphasizes again and again the fact that this land policy in the East and South-East can only be accomplished when the "subjugation of France" is completed. He was aware even then, more or less unconsciously, that for Germany the Eastern European problems are linked up inseparably with those of the West. Pan-German policy under Wilhelm II was originally based on the fiction that the advance south-eastwards with the support of the former Austria-Hungary, which was utilized as a useful instrument, and of the pan-Islamic movement then personified by the Ottoman Empire, could be accom- 
GERMANT PUSHES SOUTH-EAST plished without meeting with the inconquerable opposition of the Great Powers, especially the AngloSaxon nations.

If Hitler sees the only goal of the Third Reich's foreign policy in expansion south-east, it is a historical error if he thinks that a repetition of the catastrophic conflicts-into which Germany under the Hohenzollerns plunged to a great extent blindfoldedcan be avoided by simply declaring that he is disinterested in all colonial politics.

What we are to think of the honesty of his conviction that a one-sided policy of conquest in the south-east is possible can clearly be judged from his own writings and speeches. Even before he rose to power he had to admit that the actual expansion eastwards could take place only after "accounts had been settled" with France. In reality there can be no question of a genuine renunciation of the advance westwards even though Hitler repeatedly emphasizes that the real aim of German expansion must be sought in the east. Many years before he rose to power it was clear to him that the destruction of France, i.e., a war with the West, must necessarily precede the realization of the actual plans in East and South-East Europe.

There is, further, a psychological point to be considered, and that is that his hatred of France is almost boundless. This feeling of hatred for the "hereditary enemy" is a resentment which must be explained on the one hand from the whole German history, and on the other hand by the defeat in the Great War. In addition to these psychological reasons, one of the considerations which moved Hitler, even before his rise to power, and pan-German circles, then constantly gaining influence, was the purely strategical conviction that 
France would never suffer Hitler's long-desired campaign for the conquest of land in East and SouthEast Europe without throwing her own military resources into the scale.

The renunciation of western conflicts, proclaimed by Hitler as the great change effected by him in panGerman conceptions in the interest of his plans in the South-East, appears to a careful reader of his book Mein Kampf to be a very unsafe and doubtful conception, as the necessity of a previous defeat of France is too glaring a contradiction of such a "new" conception. He declares (page 704) that in French diplomacy there lies

an immense danger for Germany [and continues] : For this very reason France is and remains far the most redoubtable enemy. This nation, which to an ever-growing degree is succumbing to an assimilation of Negro elements, is by virtue of its adherence to the aims of a Jewish mastery of the world a constant menace to the perpetuation of the white race in Europe.

As here, and in many other places, the defeat of France is regarded as a condition of the real expansion south-eastwards, even the second point, by which Hitler believes to have proclaimed a fundamental change of direction in the former pan-German programme and in the Hohenzollern policy, proves untenable. The years I 935 and 1936 have clearly shown that the renunciation of all colonial policy, proclaimed before the rise to power, cannot be carried out in practice. In his book Mein Kampf, it is true, Hitler tries again and again to avoid at least the great mistake of a conflict with Great Britain made by the Hohenzollern politicians, and he cannot repeat often enough that the "racially allied" Great Britain must never again become an 
enemy of Germany in a future international dispute. The endeavour to secure British sympathies is in effect one of the most characteristic aspects of the foreign policy of the Third Reich, at least in the first years after the rise to power.

But even here it was soon evident that a separation of the problems of the East and West is as impracticable for Hitler as it was for the Hohenzollerns. Since about the middle of 1936 the "demand for colonies" becomes more and more prominent in German propaganda, all the more so when it is seen how closely the interests of France and Great Britain are linked up and how impossible it is for both the British and French politicians to leave Germany "a free hand in the SouthEast".

In Goering's speech of October 28th, I936, the claim for colonies is proclaimed, with a clear reference to Great Britain, with a frankness which leaves no more room for doubt. Following his statement that Germany has no colonies, the most powerful man in the Third Reich after Hitler remarked that in Germany there are 1 36 inhabitants to the square kilometre and that Great Britain, which has a population of 137 to the square kilometre, possesses "a third of the world as a colony". The developments in the early years after the rise to power already showed clearly in politics and above all in the economic field that the "great turning point", which Hitler believes to have brought about in the pan-German conception of foreign policy, is in reality unimportant.

The goal of pan-German ideology, which influences Hitler now just as strongly as it did Wilhelm II several decades ago, is the forcible acquisition of space and land treasures in East and South-East Europe by way of an 
advance along the Gentral European axis leading from Berlin via Prague, Vicnna, Budapest, Bucharest, and Sofia to Asia Minor. The National Socialists at first thought that they would be able to change the methods of achieving this pan-German goal in such a way as not to make this imperialistic advance more difficult by the danger of having to fight on two fronts.

The hope of being granted "a free hand in the South-East" by the democratic Powers in the West of Europe appears in Hitler's statements, even before he rose to power, much remoter than this hope was made to appear to the German nation; for even before he wrote Mein Kampf Hitler was fully aware of the fact that France would not allow him this freedom of action in the South-East without difficulty, and that a military victory over France would have to be the first step towards the realization of the south-east programme. Further developments have proved that even Great Britain does not believe in the thesis of a "localization of war", and cannot do so if only because of its Asiatic and overseas interests.

In practice this means an unwilling renunciation of the new conception which the National Socialist foreign politicians thought to have found in order to make pan-Germanism appear less dangerous to the world, by adopting new methods while retaining the same aims. Hitler's aims were in principle almost completely identical with those of the pan-German idcology under Wilhelm II. The attempt to alter the methods of arriving at this goal can be regarded as having failed. Consequently, Hitler's pan-Germanism today is the same as the pan-Germanism of Wilhelm II and Ludendorff, both in respect of the goals in view and of the methods proposed. 


\section{GERMANY PUSHES SOUTH-EAST}

The attempts to present the foreign policy of the Third Reich as less dangerous in comparison with the imperialism of the Hohenzollern Empire by virtue of these seemingly "changed" methods must be considered as having failed. National Socialism's conceptions resemble from year to year more closely those of Wilhelm II, despite the changes in world politics which have since taken place, so that at present it is already possible to speak of a basic identity of panGermanism today and at that time.

If there are differences, they lie at most in the fact that today the methods of deception about the true designs of the German foreign policy are more highly developed. Even Hitler himself declared clearly before his rise to power that one need not adhere to programmatic promises if it is found later that other methods are more efficacious. These tactics, which were recommended already by Machiavelli, involve a grave danger, which lies in the fact that statements and promises are regarded by other parties as binding and reliable.

Under Wilhelm II the German push south-eastwards was characterized by a series of treaties which-it must frankly be admitted-were often respected by Berlin even when they proved disadvantageous, while other states drew the motives of their actions primarily to suit their own advantage according to the situation of the moment. Pan-Germanism in its present form has procured an alibi in advance from Hitler's book Mein Kampf, to which it can appeal whenever accused of non-observance of political and economic agreements. A party which once and for all, in advance, raises breach of treaties to the rank of a principle must naturally be treated in a different way from one which 
on principle adheres to agreements once signed in order to be able to expect the same treatment from the other parties.

The numerous treaties concluded by Germany with the South-East European states since Hitler's rise to power always show the same methods, particularly on economic points : to promise something which cannot be fulfilled and which it knows-this is particularly important-even at the moment the treaty is signed that it neither wishes nor intends to keep. It is in this manner that Berlin's great economic and political preponderance in the capitals of the states in SouthEastern Europe was created, a preponderance against which it has become increasingly difficult to find means of defence.

In addition to this principle of refusing recognition of loyalty and faith in the observance of political and economic treaties, there is another factor of great importance in smoothing the way for the new version of the pan-German policy of the push south-east. It can be summarized in one word: "propaganda". The instrument of this propaganda is on the one hand the economic preponderance which is obtained by disregarding economic and financial treaties; by making the small states of South-Eastern Europe involuntary creditors of the Third Reich and bringing them into an economic stranglehold, which must naturally have political consequences.

The wide scope of this propaganda, further, includes the utilization of the German Minorities in the countries in question, which are organized by institutions in the Reich to raise claims of at first a cultural and economic nature only, and later by constantly increasing these demands and extending them to the sphere of internal 
GERMANT PUSHES SOUTH-EAST politics, struggle for autonomy, et cetera, to contribute to a considerable extent to weakening the governments of the South-Eastern European states in their foreign politics.

The position of Berlin's foreign policy regarding the South-East European governments in question is strengthened according to a carefully worked out plan, so that they are forced to make greater and greater concessions, to loosen or even entirely sever friendships with allies, and to follow more and more in the footsteps of the German National Socialist policy, the aim of which is to gain one foothold after another on the line Berlin-Baghdad, or at least to weaken any opposition which may be encountered. In addition to the much too-little-known forms of actual propaganda through National Socialist "cells", influence on the Press, literature, theatre, films, etc., and the development of numerous personal contacts, the importance of which should not be underestimated (all of which serve the same purpose, even though the people concerned themselves often do not know in what manner they are useful to the interests of pan-German expansion in the South-Eastern European states), there is finally yet another form of supporting German interests to be mentioned, which is particularly well developed in the Danube and Balkan states.

At first glance this policy seems particularly difficult to understand as its purpose is to form numerous nationalistic groups, financed by Berlin, in the internal politics of the countries in question, their programme consisting mainly in removing foreign influence of any kind and in emphasizing their own national interests to an even greater extent than is done by the governments themselves. The nationalist organizations of 63 
the Right work in many cases legally and illegally hand in hand with the German National Socialist Minorities, or very often even direct with the authorities in Germany.

Everywhere the aim is to weaken the power of the central government in the South-Eastern European countries and to increase the influence of the Reich on the external and economic policy; in short, to increase the pan-German power to the detriment of the nations in question and of their own governments.

If we, recognizing the fact that pan-German aims have remained the same and that even the methods of pan-German policy practically changed but little in principle in comparison with those of the Hohenzollern period, arrive at the conclusion that the pan-German conceptions under Hitler are almost entirely identical with those of pre-War times, we must further add that the keystone of this pan-German conception is today, as before, the "Drang nach Südosten", but that the systematically developed methods of political, economic, cultural, and propaganda tactics have today made this "Drang nach Südosten" much more effective. They have weakened the opposition, having had to work on a large number of small and medium-sized states on which this pan-German lust for expansion south-eastwards is now focused with the aid of all its resources.

The danger of an international conflagration as a result of this pan-German push south-east has grown constantly more acute, just as pan-Germanism itself has become, under Hitler, a much greater menace to the world than the pan-German policy of Wilhelm II ever was. 


\section{Chapter $V$}

THE REACH FOR VIENNA

From the very first days after the rise to power the fighting spirit of the new pan-Germanism constantly turned to Austria, despite repeated rebuffs. It may be asked why little Austria, which neither has great treasures of raw materials nor was considered historically as a particularly important aim of the German expansion, was assailed by Hitler with such vigour that even the repeated defeats suffered here could not convince him of the futility and danger of these attacks.

From an economic point of view the explanation is fairly simple if one considers that a giant chain of raw materials in the form of ore mines, petroleum fields, grain districts, etc., stretches from near Bratislava almost without any interruption as far as Persia, that the possessor of these vast reserves of basic products of all kinds would necessarily gain an unheard-of political power, and that it is just Germany's neighboursAustria and Czechoslovakia-themselves relatively poor in raw materials, which separate the Third Reich from immediate contact with this chain of raw materials.

Reasons of economic policy would make this entirely understandable if access to the reserves in the SouthEast could actually be gained by the removal or conquest of this bar, the more so as Austria and Czechoslovakia, in spite of the development of their 
agriculture, continue to be primarily industrial countries, which compete with German exports in many parts of the world market.

There can, however, be no doubt that it was not, and is not, solely or even primarily considerations of economic nature which determined the direction of the pan-German advance to be Vienna and Prague. Much more decisive here were probably certain strategical considerations and the old pan-German desire to procure in Austria, in spite of or just because of its powerlessness, which was the product of the peace treaties, a useful instrument, on the one hand to bar the Brenner frontier, and on the other hand to facilitate the actual push south-eastwards and give it a base outside the German Reich itself. The old idea of the "Anschluss", which haunted the heads of the German pan-Germanists (far into the ranks of the German parties of the Left) immediately after the end of the War, crystallized later into the customs union, when for the first time it had to be quite clearly recognized that the Great Powers, on well-considered grounds, were definitely opposed to the intended incorporation of Austria in Germany, prepared at first in the sphere of economic politics, later on political and military ground.

Despite, or rather because of, this, after Hitler's rise to power the new pan-Germanism once more directed its south-east policy towards Austria, clinging with an absolutely amazing perseverance to the conception that once supremacy over Austria was gained not only would all danger from Italy to the German plans for an expansion in the Danube basin be prevented, but also it was just the incorporation of Austria by peaceful means or by force which might be the most important stepping-stone to expansion along the Danube. 
When-after the failure of the National Socialist rising and the assassination of the Austrian Chancellor Dollfuss-it secmed that today violent attempts to gain Austria must fail in the face of the opposition of Italy and of the Great Powers alone, as did the customs union experiment, other methods were adopted. Their purpose was to remove the Italian opposition at all costs and to create, to start with, a sort of ItalianGerman condominium in Austria, which at an opportune moment could be changed into a clear German predominance if concessions were made to Italy in other fields such as would make Rome willing to discuss the surrender of Austria. The mistake in this entire calculation is, however, that such concessions simply do not exist, as the extraordinary importance of Austria and of the opening of the northern frontier for Italy was as little appreciated in Berlin under the rule of National Socialism in 1936 as it was misunderstood in 1934 and before the outbreak of the Great War.

A true understanding of the Austrian problem and concurrently of the conditions for a German-Italian rapprochement can only be gained after finding the correct attitude to the so often lightly advanced thesis of a so-called "international fascist union". Such an international fascist union is contrary to all reality, because it is in contradiction to the most important basic principles on which the ideology of the fascist movement is founded. From the point of view of foreign politics the fascist movement is based not only on the penetration of the neighbouring states by its ideology and on opposition to all co-ordination of power in units greater than the nation, but also on efforts to extend boundaries, to conquer foreign territories which can serve for the expansion of the economic, 
political, and spiritual fundaments of life of that nation itself.

The fascist ideology, in whatever form it occurs, is therefore inconsistent with the peaceful and cultural penetration of the world in the interest of an increase in the individual's contribution to the progress of mankind ; on the contrary, it is and remains an ideology of the acquisition of power by force, and the authoritative and honest representatives of the fascist teaching have never denied this fact.

This spirit of expansion, which, in spite of all assertions of peaceful intentions, is common to all fascist states, may perhaps provide the possibility of a temporary co-operation in the execution of certain definite conquests, but this co-operation must needs cease where the possibilities of expansion of two fascist states can no longer be co-ordinated.

The divergency of interest between the Germans and Italians became apparent even before the Great War, at a time when Italy was still a close ally of Germany. At the decisive voting at the conference of Algeciras regarding the Morocco problem, on January 16 th, 1906, Italy voted against Germany and AustriaHungary, as Wilhelm II's policy was irreconcilable with the Mediterranean interests of pre-War Italy. Hitler's attempt, on the occasion of his visit to Mussolini in June 1934 at Venice, to make Italy disinterested in Austria, at least conditionally, ended with Mussolini's having the Brenner Pass guarded a few weeks after the National Socialist rising, and frustrating any further penetration of Austria by National Socialism.

The German-Austrian treaty, signed in collaboration with Italy on July IIth, 1936, was another attempt on the part of Berlin to make the Italian 68 
Government conditionally disinterested in Austria. This treaty, which Mussolini later presented to the western democratic states as the "creation of the new European axis Berlin-Rome", doubtless brought Italy certain advantages in its colonial policy towards Great Britain, and it was probably only in consequence of this that the Italian-British gentlemen's agreement, which was very favourable for Rome, became possible.

The reactions of this alliance between the German and Italian fascist movements are reflected in a similar way in the Spanish conflict, as Italy's position in the international concert was beyond doubt considerably strengthened by Germany's backing. However, already in the Spanish conflict it was seen that Rome did not wish to go beyond declaring a common "antiBolshevist" policy and the presentation of threatening statements such as the "European axis Berlin-Rome". As soon as Italy's interests of a colonial, and especially economic and financial, nature demanded it, no further mention was made of the reciprocation in the Austrian question to be shown Berlin for its backing.

The Italian and German interests in Central Europe, and especially in Austria, are so strongly divergent that any actual foothold gained by Berlin in Vienna must necessarily seriously endanger the Italian policy and could not, therefore, be suffered by Rome. Hitler himself had, it is true, even before his rise to power, repeatedly asserted his sympathies for Italian Fascism, and the history of the constantly renewed attacks of the Third Reich on Vienna, which were immediately revoked as soon as Italian opposition was encountered, is nothing but a chain of Hitler's efforts not to make an enemy of Italy.

The great error of German policy under Hitler in 69 
the Austrian question remains, however, that Berlin believed, and still believes, that contrary political and economic interests can be bridged by ideological sympathies. To the Third Reich Vienna remains the indispensable gateway to penetration of the Balkans, and all that has up to now been achieved by National Socialism in South-Eastern Europe-and it has certainly not been unsuccessful-is nothing but patchwork until a completely neutralized Austria, or, better still, an Austria under Germany's influence, opens up the direct way to the Yugoslavian ores, Hungarian and Bulgarian grain districts, Roumanian oilfields, Turkish cotton plantations, etc.

For this reason no price is too high for National Socialism to gain complete possession of this Austrian gateway, and it is willing to make concession after concession to the Italian friendship. The treaty of July IIth, I936, is regarded in Germany as the first step towards the realization of the "Anschluss" and to the success of an attempt which best characterizes the entire pan-German south-eastern policy and its failures in recent decades.

In the official party paper, Deutsche Volkswirtschaft, Austria was, in 1936, expressly described as the gateway to South-East Europe and the Balkans, which may open up the Third Reich's way to Asia Minor independent of other Great Powers. They even go so far here as to call Austria by virtue of its key position, immediately after the conclusion of the treaty of July 1936, essential for the realization of the plan of making Germany a real world power, and declare that the German-Austrian treaty is the first step towards the foundation of a mighty economic empire extending over the whole of Central and South-East Europe. 
GERMANR PUSHES SOUTH-EAST

The statement repeatedly made by National Socialists that absolutely vast possibilities lie in the space between Vienna and Constantinople is essentially true ; in fact, there is hardly any area in the economic structure of the world the importance of which as a source of raw materials has been so underrated as Central and South-East Europe; it further has the advantage of possessing these treasures of raw materials almost within the grasp of the important European industrial centres, so that, if the customs barriers fall, the extraordinary increase, due to freight alone, in the cost to European industry of other countries' raw materials would guarantee their successful competition with raw materials from overseas and the colonies.

But it is constantly forgotten in Berlin that this fact long ago ceased to be the secret of the German economic geographers and military authorities. Not only have French and British interests secured valuable bases in the Balkans and in Asia Minor, which they would under no circumstances relinquish "in order to be left in peace", but Italy, above all, has built up powerful footholds in Yugoslavia, Bulgaria, Roumania, etc., which are by no means merely of an economic nature. There is certainly no other part of the Continent in which political and economic interests are so closely interwoven as in South-East Europe.

Italy, which itself has insufficient quantities of raw materials at its disposal and is certainly not in a position to exploit the possibilities of its colonial empire in the near future out of its own resources to such an extent as to create for itself the position of a world economic power which is the dream of fascism, will hardly be willing to cede its footholds in Central and SouthEast Europe to Berlin. The competitive struggle 
between Germany and Italy in the Balkans has become more and more severe, in spite of the treaty of July I I th, 1936, and it can be clearly proved in each state lying between Vienna and Constantinople to what a considerable extent German interests retire before those of Italy.*

Central and South-East Europe, to which National Socialism wishes to gain free access by neutralizing and later on annexing Austria, is, moreover, not a territory open to free colonial exploitation as, for example, Abyssinia was for Rome. In addition to the interests of the Great Powers, and especially of Italy, there exist here very strong independent strongholds of the governments concerned and their allies, particularly Czechoslovakia, which through the Little Entente endeavours tirelessly, and with more and more evident success, to carry out the political and economic process of penetration which has been going on for years.

Here, for instance, is one of the reasons for the continuous renewal of the thrusts which Berlin, after Hitler's rise to power, unsuccessfully directed against Prague, as it seems that the strategical importance of this west-eastern axis, controlled mainly by the Little Entente, also for the Western European status, is appreciated by Berlin.

While, however, this attack on Czechoslovakia means a passage of arms between National Socialism and world democracy, especially the Western European states, which are capable of intensive political, economic and military activities, and with Soviet Russia, the constantly repeated attempts to seize power in Austria mean a struggle between the two fascist states.

* Dr. Gerhard Schacher: Berlin and Rome in Central Europe. The Contemporary Review, January 1937.) 
The great blunder of German south-eastern policy under Hitler-to lay via Vienna the way southeastwards which seems impracticable via Prague-is always due to the fact that in spite of all proofs to the contrary experienced up to now, the relationship of the two fascist ideologies is considered sufficient to enable an exclusion of Italian influence by peaceful methods.

In reality it has up to now been found that the ideological link between Berlin and Rome (quite apart from the fact that it is by no means without gaps) has again and again been insufficient to bridge over this divergence of interests. For Berlin the way to Vienna is the way not only to the Balkans, but also to the Adriatic. Attempts have been made to render this obvious fact palatable to Italy in manifold ways. It was, however, impossible to deceive anyone that an empire whose axis from north to south stretches from the Baltic to Klagenfurth will naturally be anxious to attain the old German desire to reach the shore of the Adriatic when the distance is considerably less than I oo kilometres.

Strained efforts to play off the two large states on the coast of the Adriatic, Italy and Yugoslavia, against each other, is finally leading more and more to a rapprochement between Belgrade and Rome. Although their interests in many directions may be very widely divergent, both of them certainly fully agree that the dangerous northern "friend", covetous of expansion, must be kept away from the Mediterranean. Consequently, the probability that the German thrust on Austria will lead to a rapprochement between Yugoslavia, possibly the entire Little Entente, on the one hand and Italy on the other is decidedly greater than 


\section{GERMANY PUSHES SOUTH-EAST}

that one of the Adriatic states, out of enmity to the other, will make possible the "Anschluss" between Germany and Austria, and thus create the possibility of a National Socialist march to the Adriatic.

However complicated the Austrian situation may appear from the viewpoint of Vienna's internal politics, the co-operation of the Vatican, the opposition of the various groups supported by Rome, Berlin, Paris, and London according to the momentary state of affairs, this Austrian problem will become quite clear after a single glance at the map. This reveals on the one hand the danger for Italy from the thrust of the Third Reich to the Adriatic. Equally important, however, is the danger of a complete exclusion of Italy from its position in Central and South-East Europe, which it badly needs as protection for its northern and eastern frontiers.

It may now be admitted that in the development of Italian Fascism there have been at times periods of satiety in which Rome was interested solely in securing, politically consolidating, and economically exploiting its colonial conquests. This consideration might easily lead to the erroneous conclusion that the importance of its interests in Africa might induce Italy to lose interest in Central and South-East Europe. This would then be the opportune moment which Berlin could use to open up, with Italy's consent, at least the second of the two gateways-Prague and Vienna-leading to the Balkans and the Near East, if Czechoslovakia, for reasons which will be dealt with later, remained closed to the pan-German push South-East.

In spite of Mussolini's thesis of the "Rome-Berlin axis" and in spite of the clearly evident adjustment of the Italian Fascist ideology to that of Hitler, which can 
be seen, for instance, in the entirely new, sharp emphasis on Italy's position in the anti-Russian front in January 1937, a renunciation of Italy's Balkan policy is unthinkable. The strongest position which Italy holds in South-Eastern European affairs is, however, and remains its strong influence on Austria, in which it enjoys the support of the Vatican.

The "Anschluss" was the fond dream of pan-German circles in Bismarck's times, it remained so under Wilhelm II, when Austria-Hungary was regarded in Berlin purely as an instrument of pan-German policy in Central Europe, the policy which later led not only to the defeat of Germany but also to the breaking-up of Austria-Hungary and to the formation of succession states on the territory of the old Danube monarchy. The conquest of Austria as the indispensable gateway to the great economic empire in Central and SouthEast Europe under German supremacy was the unsuccessful attempt by which pan-Germanism, coming to the foreground once more in the expiring Weimar Republic, newly drew Europe's attention to its rebirth and warned it to beware.

The march on Vienna, which Hitler undertook in I934 under the erroneous supposition that he would be backed by Italy, was the first and most serious failure of the foreign policy of the new régime, as it showed Europe that pan-Germanism had merely changed its terminology, and that under Hitler its basic tendencies remained the same as under Wilhelm II. Not even the Austrian-German treaty of July I I th, I936, will be able to make the Third Reich masters of Austria-in spite of Rome's declaration of loyalty, which in 1937 almost gave the impression of a complete turn in the entire conception of Italy's foreign policy- 
although this time too Berlin believed it was extremely near its goal. The rule of Austria from Berlin is contrary to the vital interests of Italy, whatever may be the régime in power in Rome. Europe has always successfully opposed German ambitions regarding Austria, as the conquest of Vienna constitutes the overture to the realization of pan-German dreams which would not be limited even by the Bosphorus.

During the year 1937 both Rome and Berlin constantly tried to give the impression that Europe has to reckon with a united front of the two Fascist Powers on the Danube and in Mediterranean questions, particularly in Spain. These attempts at intimidation culminated in Mussolini's visit to Berlin ; in a speech there, it is true, he answered the question, "War or peace?" with a decided "Peace !" but he gave it clearly enough to be understood that Italy will support Germany's policy, just as Berlin supports Rome's.

Since the Abyssinian adventure Italy has been so dependent upon Germany's backing for its Mediterranean policy that pessimists were frequently convinced that Rome will make any sacrifice in Central Europe to preserve Germany's backing, so valuable with regard to the Western Powers. The consequence of these considerations was naturally a further increase in the disquietude in Central Europe, but it soon appeared that in spite of his certainly very difficult position and in spite of the friendly reception given him in Berlin, the Duce had by no means given those assurances in the Austrian question which Berlin desired.

Germany's thrust at Vienna, in which since the murder of Dollfuss it has again and again been forced to rely primarily on the assistance of the illegal Austrian 
National Socialists, is not likely to be able to expect assistance from Italy's foreign policy in the future either. The situation of Austria, however, wedged in between the two Fascist Powers, has become still more perilous in consequence of the fact that Rome and Berlin have undertaken mutual support in the important questions of international politics. In practice, however, this undertaking will undoubtedly always stop at the point where the vital interests of one or the other partner of the "axis" are seriously threatened ; and the Austrian problem is perhaps the most important question in which Italy's and Germany's interests clash.

But the value to Austria of Italy's protection against German National Socialism has been considerably lessened by the events of the year 1937; this, too, is one of the most important reasons for Vienna's attempt to find other possibilities of preserving the independence of the country and its foreign and domestic policy in spite of the dangerous neighbours in the North and South.

A second reason for the gradual separation of Austria from the axis Berlin-Rome-which until about the year 1936 the force of circumstances made it appear necessary to join-lies in the fact that Italy was unable to fulfil the economic assurances made to Austria. This became quite clear in the loosening of the economic treaties bound up with the Rome Protocols (in September 1937), for Italy could not take over and pay for those quantities of commodities which it had originally undertaken to purchase from both Austria and Hungary. Relations with Austria were further strained by the fact that after the conclusion of the so-called Ciano Treaty 
with Belgrade at Easter 1937 Yugoslavia reminded Rome of its undertaking to purchase considerable quantities of wood from this country. This could only be done at the cost of the Italian purchases of Austrian wood.

Both politically and economically, therefore, it became clearer and clearer that Italy-although in its own vital interests it must and will always prevent the complete annexion of Austria by National Socialism-is in its present situation hardly in a position to provide Austria with a guarantee and adequate counterweight to Germany's push South-East, thus prescrving the independence of the little country. Consequently, the old endeavour to win over Austria (as well as Hungary) for as close as possible a cooperation with the states of the Little Entente, and thus with the Western Powers too, comes more and more into the foreground.

These endeavours are really based on considerations of economic common sense, founded on the recognition that after its political collapse the old Austro-Hungarian monarchy had disintegrated into a number of small states, whose entire economic and financial structure made them interdependent, as for centuries their industry and agriculture had complemented each other. This applies in a particularly high degree to Austria's relations with Czechoslovakia; the most effective support for the plan of a close co-operation between the five most important states in the Danube basin, i.e. the three Little Entente countries, Austria and Hungary, in a great Danube Union, has been provided by the continually progressing rapprochement between Vienna and Prague in the sphere of economics and politics. All plans of 
this sort naturally appear highly undesirable to National Socialism, as they necessarily check the German thrust South-East, by considerably reinforcing the barrier chain formed by Austria and Czechoslovakia to the pan-German push towards the Balkans and Asia Minor.

The rapprochement between Austria and Czechoslovakia, primarily based on economic considerations, but of course also of great political significance, represents at the same time the first step towards a more decided orientation of Austria towards Western Europe. Austria's attitude at Geneva showed increasingly clearly even in the year 1937 that Vienna is trying to liberate itself more and more from the supremacy of the Rome-Berlin axis. This, however, led to a decided increase in Western Europe's appreciation of the extreme importance of the Austrian problem for the maintenance of the European equilibrium.

In this connection it should not be forgotten that the six Danubian countries, Austria, Hungary, Czechoslovakia, Yugoslavia, Roumania, and Bulgaria, cover a surface of well over 964,000 square kilometres, or, in other words, that the Danube territory is about twice as big as Germany, and that its population, which exceeds 69 millions, is greater than that of Germany. If by way of a rapprochement between Austria and Czechoslovakia, or rather Austria and the whole Little Entente, and of the utilization of a corresponding rapprochement between Hungary and those states of Central and South-East Europe which support collective security (the possibility of this will be discussed at a later stage) a front can be formed which is capable of checking the German push South- 
East, the peaceful tendencies in this part of the world would be considerably reinforced.

The events of the year 1937 show very clearly that these tendencies are gaining more and more ground in Austria; the nervousness with which National Socialism watches this process, and the fact that the attempt is made to place it in the light of a veritable "conspiracy against Germany", show best that this is the most suitable way of paralysing the National Socialist influence on Austria's policy without assistance from outside, by a rapprochement with the democratic Powers.

Of course, this gradual consolidation of the Danube basin, its emancipation from the Berlin-Rome axis, and the increase in its capacity to resist pan-German expansive efforts will again and again contribute to the evocation of fresh National Socialist campaigns in Austria. The frequently repeated declaration that no aggressive intentions are pursued with regard to Austria will in the long run not be sufficient to convince those who are conversant with the Third Reich's Central and South-East European policy. Since the murder of Dollfuss, Adolf Hitler's party has continually maintained at enormous cost a large number of illegal Nazi organizations in Austria, just as a large number of illegal Austrian National Socialists, who have fled to Germany, occupy high positions in the party and state there. The present intensified endeavours towards consolidation and the attempts made in Austria to obtain a rapprochement with the West of Europe, will for the time being certainly not be sufficient to sound the knell of the old National Socialist longing for a conquest of Vienna.

National Socialism's Austrian policy shows that in 80 
GERMANT PUSHES SOUTH-EAST spite of all assertions of peace pan-German ideology has not been abandoned, but that-exactly as at the time of Wilhelm II-it is to be the means of the conquest of a mighty empire in Central and SouthEastern Europe as a preliminary to world power. This pan-German ideology, however, is now, as ever, the worst menace to European peace, not only for the great democratic states in the West but also for those states which so frequently emphasize that they are natural allies of the Third Reich in consequence of the affinity between their ideologies. 


\section{Chapter VI}

THE ATTACKS ON PRAGUE

BIsmarck said once that the possession of Bohemia guarantees dominion over Europe, and the entire history of Germany provides a chain of proofs that the German races endeavoured again and again in vain to fight their way through Bohemia in order to penetrate eastwards along the Danube. If we consider that on the other hand Bohemia has always been the breakwater against the numerous attempts of the eastern races to overrun the West, the unusual strategic value of this territory, which was actually, for more than a thousand years, the field on which Europe's decisive battles were fought, will be fully realized.

Bismarck's sentence can be countered with the remark by General Fadejev, the Russian pan-Slavist, who said that without Bohemia the Slav cause would be lost for ever, and that the population of Bohemia should be considered the advance guard of Slavdom. It is true that this territory is the most important point on the transversal Eurasian axis; the reason why German military literature has dealt so frequently and intensely with this axis is that it is the shortest line of communication by land between the North Sea and the Persian Gulf, and therefore between the Atlantic and the Indian Ocean.

Even in the Great War the exceptional importance 
of Bohemia was demonstrated, to Germany's cost ; for if Germany's ally, Austria-Hungary, had put into the field a homogenous and reliable army corresponding to its population, and had contributed about 120 divisions, the Allies' operations in South-East Europe and Asia Minor would never have been so persistent nor have lasted so long as was actually the case.

Austria-Hungary, of which even Bismarck thought that the races united in it would follow their Emperor unconditionally if he called them, in point of fact assembled only about 80 divisions, as the non-German and non-Hungarian troops went over to the Allies shortly after the outbreak of hostilities, and it was just these 40 or $5^{\circ}$ divisions which failed in the calculations of the German and Austrian staffs, while large bodies of effective troops, such as the Czech Legionaries, fought in the ranks of the Allies, and were one of the most important reasons for the delay of the Central Powers' decisive victory in the South-East, which again was one of the most important premises of the whole German plan of battle.

At least as much as in the case of Austria, the statement that here both the new and the old type of pan-Germanism met a bar to the all-German thrust south-eastwards applies for the Czechoslovak Republic, formed on the territory of the former Habsburg monarchy. Accordingly we meet again and again in all spheres of the National Socialist philosophy the recognition that Czechoslovakia must be taken by storm or put out of the way by partition before the actual advance on the Balkans and Asia Minor can be undertaken.

The campaign of propaganda against Prague is therefore at least as old as National Socialism, which 
could not reconcile itself to the fact that a state which, in spite of the number of nationalities contained in it, is a self-contained democratic entity and allied to the strong military Powers of Western Europe, constituted a permanent obstacle in the way of the development of a great "Mitteleuropa", rich in economic resources, under German hegemony. Without Czechoslovakia, Italy is not in a position successfully to defend the old Germanic military route leading from the valleys of the Rhine and Main to the Danube basin.

The importance of Poland, too, in the international play of power, is inseparably dependent upon the existence and vitality of Czechoslovakia, as only this state gives Poland the chance of blockading the old Mongol-Germanic military route from the North via the Moravian plains to the Danube basin.

Finally, a large part of the importance of Czechoslovakia consists in its providing Roumania with the ability to close the old Mongol route leading over the East Carpathian mountains and the Užok Pass into the rich and valuable valley of the Danube. E. Moravec, in his very thorough work on the strategic importance of Czechoslovakia for Western Europe, demonstrated the indispensability, so often underestimated, of a strong and sound Czechoslovakia for the maintenance of the status quo in Europe east of the Rhine and consequently in the entire Old World, and his remarks in this connection can be endorsed :

If Czechoslovakia were removed from the arc of mountain states protecting the southern section of Central Europe, all the three old military routes to the Danube basin would be open : the western, Germanic route, the 
northern, Mongolian-Germanic route, and the eastern, Mongolian route. By crushing Czechoslovakia Germany would regain 480 kilometres of the transversal Eurasian axis, which, together with the 200 kilometres in Hungary, would mean a length of 1150 kilometres in all.

And Germany did use Austria-Hungary, in the second half of the nineteenth century, to open its way to the Balkans and Asia Minor. Today it would be quite sufficient to gain possession of Czechoslovakia to attain final rule of Central Europe and the Danube basin.

National Socialist Germany recognized in its very beginnings, more or less consciously, what a serious and almost impassable hindrance the existence of this state was for the resumption of pan-German plans of conquest along the line Berlin-Baghdad. This recognition provides the main reason why all methods of propaganda were exhausted in the attempt to weaken Czechoslovakia and increase the influence of Berlin in the land of Masaryk and Beneš to such an extent that this country could no longer fulfil its natural function as a bar to the pan-German expansion south-eastwards. The main directions taken by National Socialist propaganda against Prague are on the one hand an attack on the pacts of security concluded by Czechoslovakia with Paris and still more with Moscow, on the other hand the Czechoslovak minority problem, and attempts were made even before Hitler seized power to utilize this as a good point of attack on Czechoslovakia.

The slogan of the "French vassal state" dates back to the peace treaties, and the fact that Czechoslovakia, for its own safety and that of the newly-formed states of the South-East, sought and found an improvement 
GERMANT PUSHES SOUTH-EAST of its system of alliances in the Little Entente on the basis of the status quo, contributed still more to make the attacks against Prague's system of security and alliances one of the most important foundations for Berlin's anti-Czechoslovak propaganda.

This propaganda, primarily directed against the Czechoslovak-Russian alliance, lacks a logical basis, even if only because Germany's foreign policy, for some time after Hitler's seizure of power, was founded on close and friendly relations with Soviet Russia, and this at a time when neither Paris nor Prague had concluded the defensive pacts later arranged.

It is well known that German foreign politicians, by recognizing and concluding close treaties with Soviet Russia, adopted at Rapallo, already, the principle that a race of nearly 200 million people cannot be excluded from world politics, even if that country's form of government does not appeal to various European states. It will further be remembered that it was this very Czechoslovakia whose legionaries had already taken up the struggle with Bolshevism during the Great War, and that after its foundation, and particularly after the proclamation of the soviet state in Hungary, the young republic had several opportunities of preventing a further penetration of Bolshevism.

The old theory of a "pan-Slavism" which Berlin utilized for propaganda purposes again and again even during the War is hardly more senseless in connection with any other state than it is in the case of Czechoslovakia, as all who are acquainted with the history of this country know well that before the establishment of the republic the tendency of an approximation of the new state to Russia, represented 
by Kramár, had been superseded by the theories of Masaryk and Beneš, which politically, culturally, and economically were much more thoroughly developed. The entire theory of the two state-makers was based on as close as possible a relation to the democracies of Western Europe. Dr. Beneš, in particular, proved by all his political actions, such as, for example, the establishment of the Little Entente, which contained on the one hand the non-Slav nation Roumania, while on the other hand Poland, which is largely inhabited by Slavs, was not included, that for him the propaganda slogan "pan-Slavism", which Germanic propaganda on suitable occasions again and again revived, has no longer any vital meaning at all for him.

As late as at the end of 1936 Dr. Beneš considered it advisable, although pan-Slavism today has no meaning at all in Czechoslovakia, or even in Poland and Russia, to throw historic and political light, in a leading article entitled "Pan-Slavism" which appeared in the Prager Rundschau (No. 6, 1936, pp. 40I-I4), on the true grounds for the allegation of the existence of a sort of conspiracy of the Slavonic nations against the rest of Europe. His argument that the form of the so-called "cultural pan-Slavism" consisted in a kind of fellowship against the oppressors, until these nations gained their freedom through the establishment of state-entities of their own, must be admitted.

A certain feeling of community between the oppressed against the oppressors can be found again and again in history, and there is no reason to assume that just the Slavonic races, which were oppressed by the Germans, Magyars, Turks, etc., could and should 
constitute an exception. A certain contact between the Slav races on cultural territory naturally exists even today, just as it exists, for example, between the Anglo-Saxon, Scandinavian, and other nations.

The expression pan-Slavism, used by German propaganda for decades, because, as the German proverb says, the blow is the best parry, and because it is thought that this thesis was best suited to counteract the entirely different conception of panGermanism, which has already been discussed here, has in effect a quite different meaning. This meaning is of a purely political character ; and Berlin's only, purpose in the usual "warnings against pan-Slavism" has always been to distract Europe's attention from pan-German desire of expansion and put another enemy before it.

It is psychologically interesting that these endeavours by National Socialism, very similar to the former all-German conception, take the field against panSlavism very much in the same way as against Judaism, for example, or "Bolshevism". The root of these attempts is ever the same: the desire to distract attention from their own imperialist and aggressive policy of expansion by presenting a much more dangerous "public enemy" as a target. Dr. Beneš, who, as has already been said, admits a certain cultural pan-Slavism, particularly at the time of the small Slavonic nations' servitude, and considers that the Slavs, like other racial families, are entitled to a certain feeling of cultural community, finds in the above-mentioned article very clear definitions with regard to political pan-Slavism, such as is again and again nailed up by German National Socialism today. He says there : 
GERMAN PUSHES SOUTH-EAST

For me political pan-Slavism belongs to the past, just as pan-Russianism is and must be dead today. The rest of what is wrongly called pan-Slavism shall be given its true name. All that has, as I have just indicated, experienced such changes through the Great War, the new organization of Europe, the liberation and union of the Slavonic races and the Russian revolution, that it cannot be hard to take the right attitude towards these things.

For all these reasons I was and am opposed to panSlavism, against its theory and its content. I consider it dead.

In view of Dr. Beneš's reputation as an historical and political personage it will probably be difficult, after such a statement, to try to assume that there is any more truth in the propaganda slogan of panSlavism, recently again revived by pan-Germanism, than is here stated by the founder of the Czechoslovak Republic, the man who for many years has directed its foreign policy, and who closed the pact between Prague and Moscow as a defensive pact, with the express permission of the League of Nations.

Nevertheless, National Socialist propaganda has again and again occupied itself with the defensive pact between Czechoslovakia and Russia, and tried to make it appear a danger for Europe. It is a part of the principle of a sound foreign policy, however, that concrete moments of foreign policy, and no other, may be taken into consideration, least of all the question of its treaty-partner's momentary form of government. Thus Czechoslovakia, for instance, although it is the only Central European state which has retained a democratic form of government without interruption as the only form possible for it, concluded a treaty of very close co-operation with Fascist Italy as early as 1924. And Pilsudski's coup d'état made no 
change at all in the relations between Poland and Czechoslovakia until the attitude of Poland's foreign policy itself gave rise to such a change.

The treaties with Germany, too, have been maintained unchanged and even extended, although National Socialism's seizure of power turned the Weimar Republic into a state which certainly cannot be brought into harmony with Czechoslovakia's constitutional views. Moreover, Hitler himself declared-this fact is all too often forgotten, not only in Germany-in 1933 :

The struggle with communism is our own internal matter, in which we will never suffer interference from abroad. Our state's political relations with other Powers with whom common interests unite us $*$ are not affected thereby.

The treaty of friendship concluded in 1926 between Germany and Russia was prolonged by Hitler himself, and on this occasion it was clearly stated that a sharp distinction was made between the communist ideology and the Soviet. This policy can best be described by saying that Soviet Russia did not threaten world peace as long as its relations with Germany in the sphere of foreign politics were friendly.

Later, things changed entirely when the Soviet Union concluded a pact of mutual defence with France, in which connection alone the CzechoslovakRussian pact must be considered. The policy of the National Socialist régime was aimed straight at a division of Europe into two parts. National Socialism saw its real goal for expansion in East and South-East Europe, just as did the all-German policy at the time

* He spole here particularly of Soriet Russia. 
GERMANT PUSHES SOUTH-EAST of Wilhelm II, which suffered shipwreck in the Great War.

In order to make this expansion to the East and South-East possible, however, as Hitler emphasizes, with a frankness which can hardly be exceeded, in his Mein Kampf, the previous defeat of France is necessary. In the moment these two objects of attack, which were to be settled one after the other, but not at the same time, concluded a pact of mutual defence which allowed both the Western and the Eastern objective to rely upon the help of the other party if such an attack were to be made, it was clear that this plan was frustrated. If National Socialist Germany really held no aggressive intentions, it could see no danger in such a purely defensive pact. But as it was not willing for aggressive intentions to be attributed to it before all the world, a change was made in the tendency of German propaganda, and it was stated that Russia, for ideological reasons, had aggressive intentions with regard to Germany and even against the whole of the rest of Europe (and probably against the two Far Eastern states, China and Japan). The pact between Moscow and Paris was suddenly interpreted as French support for the aggressive intentions of Russia, and at the same time the propaganda against Prague was let loose, with the argument that the Czechoslovak-Russian pact has given the Russian attacker a free path to Central Europe and the Danube basin.

On unhurried and objective consideration it can hardly be assumed that the defensive pact concluded with Paris and Prague could be a useful instrument for the furtherance of Soviet Russia's imputed intention of attacking the peace of Europe. It is equally 
improbable that aggressive intentions against Germany are held in Czechoslovakia, and still more improbable that the pact concluded with Moscow, the defensive character of which was recognized by the competent tribunal, the League of Nations, could serve to facilitate and support such a Czechoslovak attack on Germany.

On the other hand, Czechoslovakia's potential warvalue, which is limited even if only by this country's very much lower population, is very much smaller than that of Germany. Its strategic position on its other boundaries is certainly anything but reassuring. Above all, however, Czechoslovakia has given again and again, since Hitler's seizure of power, so many proofs of its desire to maintain not only correct, but if possible friendly and neighbourly relations with Germany, that it would be absurd to believe such a hypothesis.

Further, it needs very little thought to gain the conviction that there is hardly any state in Europe which would willingly allow itself to become the arena of a German-Russian war, or even allow the armies to cross its territory, as would have to be the case if the ideas put forward by German propaganda are to be led to a logical conclusion. The conclusion of any military treaties or fronts at all, which might in the slightest contribute to the danger of war, has been considered by Czechoslovakia ever since its creation as an extreme peril, and the entire foreign policy of this country has been continually guided by the principle that everything must be done to prevent the formation of such fronts. A single glance at the map will make it clear to anyone that Czechoslovakia's foreign policy has always been guided by this prin- 
GERMAN PUSHES SOUTH-EAST ciple, and just why this principle has necessarily continued to determine it.

That in the course of this campaign of propaganda against the defensive alliances concluded by Moscow with Prague and Paris the most improbable statements were made, which could at all times be contradicted by facts without any difficulty, can only be understood from the point of view that National Socialism's idea of foreign policy was such that it was believed absolutely necessary to maintain a separation of East and West, or at least to renew it by force of propaganda.

It is unnecessary to go in detail into the assertions made in such numbers by Berlin, presenting Czechoslovakia to the rest of Europe as a sort of Russian colony and a herd of Bolshevism. It is unnecessary, as everyone who knows the circumstances, social structure, history and political views of Czechoslovakia understands quite definitely that this very bourgeois land must be considered typical of a bourgeois democracy, and that any other form of constitution than a parliamentary democracy could neither be introduced nor maintained there. But it is further unnecessary to repeat and disprove these propagandist theses, which by the way have already been criticized thoroughly by the Press of the world, as what has been said up to now has clearly shown for what reasons Berlin had to resort to this propaganda.

The conclusion of defensive treaties between Russia, France, and Czechoslovakia destroys once and for all the possibility, so warmly desired by National Socialism, of dividing Germany's two great fronts and settling first the West, and then the East and SouthEast, when the democracies of the West, after their 
defeat by the shock of the German attack, had no longer the possibility of defending the line BerlinBaghdad.

This line Berlin-Baghdad, and particularly the chain of raw materials stretching from Hungary through Roumania, Yugoslavia, Bulgaria, Greece, and Turkey as far as Asia, remains the aim of German imperialism, whether it took the shape of panGermanism under Wilhelm II or, as now, that of National Socialism, the ideology which is to save the world. The methods, too, of preparing this expansionthrust remain in principle the same: not only the utilization of Austria, i.e. the reach for Vienna, but also the removal of the Czech island, whose shores are washed by a sea of Germanic and Magyar races, and the attack on Prague. The reason for the push East and South-East was then given as the danger of pan-Slavism; today Berlin has discovered in the word "Bolshevism" at least as efficient an instrument of propaganda.

The push South-East, which Hitler once, abandoning all colonial claims, described as the most important point on the programme of German foreign policy, strikes a hindrance difficult to overcome for the first time in Prague. Strictly in the tradition of the old methods of propaganda adopted by panGermanism, for which expressions like "Yellow Peril" and "pan-Slavism" were characteristic, the civilized world is today invoked against a common foe, and without any regard for actual facts the most improbable statements are made with the object of presenting Czechoslovakia, a country of fifteen million inhabitants, which was very aptly described by a British journalist as "perhaps the most bourgeois country in 


\section{GERMANT PUSHES SOUTH-EAST}

all Europe", as a fulcrum of Bolshevism and the most dangerous aggressor against European peace.

In point of fact it is clear now that German propaganda has rebounded off Czechoslovakia. It must be constantly borne in mind that these attacks on Prague, as has already been said, move in two directions. On the one hand National Socialist propaganda's real struggle is with the Czechoslovak foreign policy; in addition to the constant repetition of the slogan, "Bolshevism's aeroplane-carrier", we meet here, again and again, with propaganda against the Little Entente, for the instigators of this propaganda are clear that the policy of the Western European democracies finds an exceptionally important support in South-East Europe in the shape of this alliance, concluded for the purpose of maintaining the status quo in the Danube Basin.

In addition to this attack on the foreign policy itself, we find as a second characteristic of National-Socialist propaganda against Czechoslovakia Berlin's endeavours, noticeable in all the states of South-East Europe, to foment internal dissension in the state attacked. This interference in internal politics has, further, the object of weakening the state's civil and military position in order to make it ripe for the final German advance. This fomentation of internal dissension as a weapon in the campaign of propaganda against Czechoslovakia is mainly effected by supporting all attempts to gain self-government made by the Minorities in opposition to the central authority, above all the German Minority, which the propagandists try to make as effective as possible through the organization of the Henlein Party. While towards Western Europe the propaganda slogan of "Bolshevism" is used, the attack against Prague is 
supported by the acquisition of an important foothold in Czechoslovakia itself.

This method of reinforcing the opposition, which by the way is by no means confined to the German Minority, but applies also to the other Minorities in the state and is extended further-at least in the other South-East European states-to the fascist movements in the countries themselves by financing terrorization, etc., will be specially discussed later. At this point it is only necessary to state that the push South-East, as expressed in the attacks on Prague, is prepared by no means exclusively through propaganda limited to the sphere of foreign politics, for example by the slogan of a "struggle with Bolshevism", but at the same time by the fomentation of internal dissension in the countries in question.

Up to now Czechoslovakia has been better able to withstand these attacks than any other state in Central or South-East Europe. It is characteristic that in the case of Czechoslovakia the resistance arose, not in consequence of the vital interests of a neighbouring Great Power, but almost exclusively out of the country's own resources and by virtue of an effective utilization of its existing alliances. National Socialism's push South-East continues to be directed primarily against the states of the Little Entente (Czechoslovakia, Roumania, Yugoslavia), and it is important to note that it is Czechoslovakia that has been able to develop the strongest opposition.

In consequence, the endeavours to smash up the Little Entente, and especially to separate the two other members, Roumania and Yugoslavia, from Czechoslovakia, were intensified from year to year.

As will be shown at greater length in the next chapter, 96 
GERMANY PUSHES SOUTH-EAST this policy, if it attains its object, must necessarily lead to an isolation of Czechoslovakia. It is evident that attempts are being made to place Prague definitely before the alternative of either preserving the structure of the Little Entente in its present form and remaining an inseparable ally of Bucharest and Belgrade, or of taking into the bargain, in order to retain the Soviet pact, a gradual loosening and finally a dissolution of the Little Entente.

If it were really possible to compel Czechoslovakia to decide finally for one side or the other, its isolation would be completed. For without the continuation and strengthening of the Little Entente the alliance with the Soviet would be practically useless, as in time of need Russia would have no direct strategic access to Czechoslovakia in order to protect it, if Czechoslovakia were alienated from Roumania and Yugoslavia.

On the other hand the Little Entente alliance would lose very much of its military and political value without Russia's backing, as there would be no protection for Eastern Europe to correspond to the Maginot Line in the West if a German attack westwards could not be countered by a corresponding defensive force in the East.

Up to now Czechoslovakia, by very acute guidance of its foreign policy and by developing suitable resistance to National Socialism's repeated attempts to foment internal dissension, has always been able to avoid the danger of such a choice between the Soviet Pact and the Little Entente Pact. This all the more so because an impartial estimate of the situation in South-East Europe shows that the Soviet Pact is not only by no means inconsistent with the Little Entente treaties, but that in fact these two pact systems supplement each other. 
In consequence of Prague's resistance the National Socialist foreign policy inclined more and more to work upon the two other members of the Little Entente and to adopt this method of forcing Prague to give up the Russian Pact, all the more so as Berlin was quite clear that a severance of the alliance between Prague and Moscow, achieved by this indirect route, is the most important stepping-stone to the cancellation of the Franco-Russian defensive pact, which Berlin is so anxious to achieve.

The attempts instituted in Roumania and Yugoslavia to obtain a dissolution of the Little Entente and consequently an isolation of Czechoslovakia and even of France will be discussed in detail later. The concentration of these attempts on the two Balkan members is, however, in any case a consequence of the stubborn resistance which Czechoslovakia has up to now been able to oppose to a preparation of the German thrust to the South-East.

That this advance with a preponderance of Germany's political and military resources was planned to take a south-easterly direction there can have been no more doubt whatever in the Little Entente states, at least after October I4th, I936. When King Leopold II of Belgium on this day changed the policy of his country from one of support for the League of Nations to a principle of mere defence of Belgian territory, the conviction gained more and more ground in the SouthEast that Brussels must have received assurances from Berlin which left room for no other conclusion than that Germany's main advance would be eastwards and not westwards, and that Belgian territory was to be protected in this case.

It may be left undecided whether and to what extent 98 
declarations of this kind can be considered as reliable. But at any rate, from this time on at least there could be no doubt in South-East Europe that the maintenance of the Russian pact and of the treaties between the states of the Little Entente were the most important and most necessary protection against the German push South-East.

The thesis of the impossibility of localizing peace and war of which both Beneš and the Roumanian Minister for Foreign Affairs, Titulescu, made the cornerstone of their policy, was not allowed to lose weight even after Titulescu's loss of his ministerial position. The attitude of Roumania, which belongs to both the Little Entente and the Balkan Entente, towards Russia, and the attitude of much-courted Yugoslavia, are becoming more and more important for the fate of Central and South-East Europe.

Up to now Czechoslovakia has shown that it is strong enough to resist all temptations and the drumfire propaganda let loose by the National Socialist politicians. Will Roumania and Yugoslavia prove to have the same strength? Will the Little Entente continue to be a pillar of collective security for Europe? These are the questions which must now be answered in order to gain an idea of the forces opposed to the German push South-East. 


\section{Chapter VII}

THE STRUGGLE WITH THE LITTLE ENTENTE

The principal object of the alliance between Czechoslovakia, Roumania, and Yugoslavia, since its establishment under the denomination "Little Entente", has been to guarantee the maintenance of the status quo in Central and South-East Europe. This league of three states, of which the last two are also members of the Balkan Entente, is therefore directed against revisionist plans in any form, that is originally against Hungary's revisionist efforts and the constantly renewed attempts at a restoration of the Habsburg monarchy.

In spite of the close connection between the three states and France, which resulted from the peace treaties, for the duration of the Weimar Republic the relations of the Little Entente with Germany were not only entirely correct, but occasionally even friendly. The aim of these states' endeavours and of the treaties which they concluded with one another was purely to secure their possessions. None of the three members had by the peace treaties acquired any territory worth mentioning at Germany's cost. The new order in Central Europe and the static endeavours of the Little Entente, directed primarily against the Hungarian country noblemen's desire for territorial reconquests and the restoration of the Habsburg monarchy, at first excluded friction with Berlin; only in the Austrian 
GERMANT PUSHES SOUTH-EAST question did it come to occasional disputes, and even for these a solution was always found in the end.

When, however, the pan-German attempt at a push South-East was again given a prominent place in German foreign policy, the situation had to change. As has already been said here, attempts to effect the push South-East via Austria failed, and even the treatics concluded under Italy's aegis in 1936 between Vienna and Berlin were absolutely inadequate to open up the way for National Socialism through Austria to the South-East, particularly to the land treasures of the Balkans and Asia Minor.

On the other hand, the opposition of Czechoslovakia, on the other route leading via Prague to Hungary and the Balkan countries, proved too strong for all National Socialism's attacks, largely because Prague could rely on both its allies Roumania and Yugoslavia, who were equally interested in the maintenance of the status quo in this part of Europe. A victory over the Czechoslovak hindrance would necessarily awake the united opposition not only of Czechoslovakia's allies in the West, but also, and in a still greater degree, of all those states which are interested in the maintenance of the existing frontiers. This would be all the Balkan states, except the revisionist countries, among which could be included Hungary and at times even Bulgaria ; they could, moreover, in more than one respect rely on the backing of Russia, Poland, and Turkey.

At the moment of realization that Prague's opposition to the German push South-East could not be broken without a European war, German imperialism was, therefore, faced with a self-contained complex of alliances. From this moment it can be seen from Berlin's policy that it is convinced of the necessity of 


\section{GERMANT PUSHES SOUTH-EAST}

rendering these alliances, especially the Little Entente, ineffective or, best of all, severing them altogether, in order to make an isolation of Czechoslovakia possible.

The Third Reich's endeavours to alienate the other two members of the Little Entente from Prague appear, therefore, at least as important as the campaign against Czechoslovakia's foreign policy and internal unity, which is carefully followed by the Press of the whole world. In spite of the general and at least partially justified conviction that Yugoslavia, by virtue of its military strength and its extraordinarily important strategic position, is perhaps the most courted state in Europe, it seems best, in a discussion of the Third Reich's south-eastern policy, to consider first the situation of Roumania.

A closer study of the map clearly shows that Roumania's separation from the Little Entente, and much more so an alliance between Bucharest and Berlin such as Berlin is striving for with all its resources, would give German National Socialism a free path south-eastwards. Such a development would be equivalent to a complete political and strategical separation of Czechoslovakia from Russia. Should Berlin succeed in winning over Roumania, the isolation of Czechoslovakia and the absence of any military help from Russia in case of Germany's attack on the former country would be ensured. One of the two barriers which close the way to the South-East, that is Czechoslovakia, would be removed by the dissolution of the alliance existing between Prague and Bucharest, and after the defeat of an isolated Czechoslovakia Berlin would have the coveted free path, leading over the plains of Hungary and Roumania as far as the 
GERMANT PUSHES SOUTH-EAST

Black Sea and the most important spheres of interest of Russia and the British Empire.

On the other hand, the maintenance of close friendship between Bucharest and Prague means the strategical possibility of help from Russia in the event of Germany's advance on Bohemia, Moravia, and Silesia. Bearing in mind these circumstances, it is easy to understand the constant willingness of the National Socialist foreign policy to make sacrifices for the sake of a friendship with Roumania, even if we do not consider the great economic resources of Roumania itself.

Every effort is therefore being made, especially in Roumania, to accomplish its withdrawal from the Little Entente. Berlin is evidently clearly aware of the fact that Roumania, whose territory was considerably enlarged by the peace treaties at the expense of Hungary and Bulgaria, would never be satisfied with Germany's friendship if this, at the same time, had to involve concessions to revisionism, especially of the Hungarian variety.

The situation here is similar to that of Berlin's policy in Yugoslavia, and consequently Germany is faced with the choice of either definitely opposing Hungary's revisionist wishes, which would mean a complete loss of this most important south-eastern friend, or of abandoning all hope of loosening the Little Entente and of the close friendship with Roumania necessary for the isolation of Prague.

The German propaganda has often been known to have opposed Hungarian revisionist desires in many ways, especially since 1936, but in Bucharest as well as Budapest the impression prevails that this renunciation of Hungary's support would not stand being put to a 
serious test. However the case may be, these declarations of anti-revisionism made by Berlin from time to time have definitely strengthened Hungary's tendencies to see its real protector in Rome, and, as will be shown later, its friendly relations with National Socialism have become perceptibly cooler. The constant repetition since 1936 of Berlin's declarations of opposition to Hungary's revisionist desires had proved decidedly insufficient to win over Roumania.

The question whether and to what extent Roumania would join the Prague-Moscow alliance in a serious emergency continues open even after the departure of the Roumanian Minister for Foreign Affairs, Titulescu, who was a trusty friend not only of the Little Entente but especially of a policy based on the line PragueBucharest-Moscow. From the point of view of foreign policy and strategy, it must be impartially admitted that by this decision Roumania would actually check the push South-East.

It can further be admitted that the existence of Roumania in its present shape is dependent on such a decision, which must not be made on consideraions of ideology and sentiment. All these questions have constantly occupied the minds of the Little Entente and Bucharest politicians even after Titulescu's departure ; it cannot be supposed that National Socialism's prospects of definitely winning over Roumania, isolating Czechoslovakia, and gaining the path to the Ukraine and the Black Sea, building up a powerful National Socialist colonial empire on the territory inhabited by Slavonic and Romanic nations, have become particularly promising in consequence of the vicarious renunciation of Hungary's revisionist desires.

The recognition of the very limited possibilities of I 04 
winning over Roumania offered by propaganda operating purely in the sphere of foreign policy thereafter induced Berlin to an ever-growing degree to shift the centre of gravity of its attempts to gain this keystone to its plans for expansion south-eastwards more and more to other fields. This was done, on the one hand, by intensifying economic propaganda, and by Dr. Schacht's activities in Roumania, which are hardly distinguishable from actual political endeavours.

In the case of Roumania, this is of quite especial importance for Berlin, as, when waging the war of the future, National Socialist Germany is absolutely dependent upon Roumanian mineral oil, which it will badly need for supplying its motorized army.

These problems met by the economic policy pursued by Germany in Roumania will be specially dealt with later, as it is not only in Roumania's case that Schacht's system of making the South-Eastern states economically dependent on Germany is perhaps the most important preparation of the intended military advance.

On the other hand, the instruments of the National Socialists in Roumania have always followed the principle of weakening all the existing democratic forces and the central power in all its aspects whenever, from considerations of the security of the state entity, these elements opposed the National Socialist forces. According to a statement made by the vice-chairman of the Roumanian National Peasants' Party, Dr. Lupu, many millions of lei have been spent on propaganda in Roumania in the last three years. Hundreds of newspapers were founded out of these funds, and terrorist organizations, whose aim was a rapprochenient with Berlin, were provided with weapons in large quantities. Dr. Lupu expressly stated that it was not 
only gold that came from Germany, but also machineguns and hand-grenades for the terrorists. According to very reliable French information, in the year 1936 alone not less than 600 millions of lei were spent by Berlin's "Propagandaministerium" on this propaganda, and in particular the control over eighty Roumanian newspapers was secured.

In Roumania, just as in Czechoslovakia, these efforts to bring about internal dissension started by influencing the German Minority, in which Hans Roth holds about the same position as does Konrad Henlein in Czechoslovakia. The utilization of the German Minority to further National Socialist propaganda and to weaken the central power and its foreign policy will be dealt with more fully later, as Roumania is no exception here, for the German Minority is always utilized as the advance guard of National Socialism's propaganda in the South-East.

A point which has a much more characteristic bearing on Roumania, and which also falls within the sphere of National Socialist interference with the internal politics of the South-Eastern European states (which will be dealt with later), is the financing of Roumanian National Socialist anti-Semitic, and fascist terrorist groups, whose political importance is constantly increased by Berlin's support.

It should be mentioned here and now that Roumania can be taken as a characteristic example of how the National Socialist opposition, working with methods of terror, is supported by Berlin in the same manner as the German Minority; in this latter case, however, attempts are made to justify the subventions morally, at least on the surface, by the "common blood and race". Here the German Minorities, financed openly 
GERMANT PUSHES SOUTH-EAST

by Germany, already work hand in hand with other organizations, enjoying the same financial support, which have inscribed on their banners, in addition to anti-Semitism, the slogan "Everything for the Fatherland".

The real aim of this opposition in Roumania, which is financed to an enormous extent by the Ministry of Propaganda in Berlin, is neither the struggle with the Jews nor a fight against Bolshevism as a world-philosophy or economic system. Its real object is to be sought solely in the sphere of foreign policy. Efforts are made to weaken the central authority and the democratic forces which cling to the maintenance and development of alliances as the most important thing for the country. By weakening these forces it is hoped to achieve the dissolution of the Little Entente, the isolation of Czechoslovakia, and an open path to the South-East.

From the point of view of foreign politics Roumania's situation distinctly requires that the Little Entente should not only be maintained but even strengthened. The seemingly so patriotic opposition which, with the aid of means from German sources, applies pressure on the central authorities, seeks to loosen the Little Entente by the methods of internal politics, as it cannot be done on consideration of expediency with regard to foreign policy.

After Titulescu's departure in 1936, the communiqué of the Little Entente conference held in September in Bratislava voiced the principle that in spite of the essential maintenance of the treaties all three states can pursue the policy of concluding treaties with other countries as long as they think that their independence will thereby be increased. In the official Roumanian 


\section{GERMAN PUSHES SOUTH-EAST}

press these stipulations of paragraph 3 of the communiqué were interpreted to mean that, just as Czechoslovakia has the right to conclude a treaty with Russia, Yugoslavia is entitled to make corresponding treaties with Germany, and Roumania with Germany and Italy.

The instigators of German propaganda in Roumania long ago realized the extraordinarily important position of that country and are constantly intensifying their efforts to separate Roumania, whose petroleum, moreover, Germany so badly needs, from the Little Entente.

This propaganda is, of course, as in most countries in the South-East, put into effect mainly by influencing trade and internal politics. Of that we shall speak later. If it is asked why Germany does not try to attain its aim in Roumania and also in Yugoslavia by concessions and allurements purely in the sphere of foreign politics, as it does in Poland, the reply is to be sought in the revisionist problem.

It is really difficult, if not entirely impossible, for a revisionist Power, which is at the same time closely linked up with other revisionist states such as Italy and Hungary, to impress upon the foreign politicians of the anti-revisionist states, such as Roumania and Yugoslavia, the conviction that they have interests in common. This is the decisive point on which all endeavours to arrive at a really close co-operation with Bucharest and Belgrade in the sphere of foreign politics have again and again been wrecked, for, whenever Berlin believed that some progress had been made, developments convinced these states that their vital interests cannot be co-ordinated with those of Germany.

Germany wants to change the map of South-East Europe. This rearrangement of frontiers could, after I 08 
GERMAN PUSHES SOUTH-EAST all, be carried out only at the expense of the states united in the Little Entente and the Balkan Entente. If one or the other member of these two Ententes, especially Roumania or Yugoslavia, which are members of both, withdrew, in consideration of some promises from Berlin, from these agreements, it could only be done at the cost of part of the territory of the states in question.

For this reason Germany's efforts to conclude some bilateral treaties with the states in question have always been unsuccessful. From this chain of failures Berlin drew the conclusion that neither the Little Entente nor the Balkan Entente can actually be broken up by methods of foreign policy, and its south-east policy was given a new direction. This consisted in endeavours now made to give the Little Entente and the Balkan Entente a different meaning. Apart from the methods of Schacht's economic policy, attempts to attain this aim primarily took the shape of constantly increasing National Socialism's influence on the internal politics of the states of Central and South-East Europe.

A change in the methods of the German south-east policy can be noticed since at least 1935. In all antirevisionist states we encounter efforts by German propaganda, on the one hand to strengthen the Minorities and form them into a useful instrument in the struggle against the anti-revisionist foreign policy of the governments, and on the other hand to fortify all anti-Semitic, anti-Russian, anti-French, and antidemocratic groups and parties in the states concerned at the expense of the democratic tendencies; for it is known that such support for the internal opposition is most likely to lead, by weakening and changing the 


\section{GERMANT PUSHES SOUTH-EAST}

governments, to progress towards the aims of German foreign policy, which in view of the situation of the revisionist problems in Central and South-East Europe have been allowed to remain in the background for the time being.

Just as every effort is being made to strengthen the Henlein group in Czechoslovakia and the German and Hungarian Minorities in Roumania and, at the same time, to support the right wing of Roumanian terrorists of all descriptions, in Yugoslavia the efforts of the German south-east policy, apart from economic propaganda, are focused on strengthening the opposition of the Minorities to the Belgrade Government. The Yugoslav Government itself has never left any room for doubt that it holds absolutely anti-communist views, that it refuses to recognize Russia and still less to make a treaty of friendship with it, and that in more than one respect it desires co-operation with Germany, particularly in the economic sphere.

On the other hand, in Yugoslavia there live, in addition to the main Serbian nation, not only about halfa-million Germans and approximately the same number of Hungarians, but also a strong Slav Minority comprising over three million Croats and a million Slovenes, quite apart from the small Minorities such as the Albanians and Roumanians. A close alliance of its foreign policy with that of the strongest revisionist Power in Europe, National Socialist Germany, which, moreover, would not like to renounce its close relations in foreign politics with Italy and Hungary, would mean such great danger for Yugoslavia today that no responsible Yugoslav statesman, whatever his worldphilosophy may be, could assume the responsibility for a foreign policy advocating a withdrawal from the 
GERMANT PUSHES SOUTH-EAST Little Entente in favour of as close a rapprochement with Berlin as possible.

In addition, it must be considered that, in virtue of Yugoslavia's particularly favourable strategic position, there are other countries, especially the great Western Powers, Great Britain, France, and, last but not least, Italy, who are anxious to win it over. Consequently, the German propaganda concentrates more and more on the endeavour to intensify the pressure of the Minorities, especially the Croats, on Belgrade.

Early in February 1936, the Yugoslav Prime Minister, Stojadinovič, declared that Yugoslavia would pursue neither a germanophil nor francophil or italophil policy, but a Yugoslav policy only. Even if for any reason Belgrade did want to renounce the traditional policy it has pursued since the foundation of the new state in favour of a pronounced gravitation to Berlin, it would not be in a position to do so. The exceptional advantages of Yugoslavia's strategical and political position involve at the same time the necessity for cooperation towards collective security, and the obligation not to abandon this principle in favour of unilateral ties.

The impression may have prevailed more than once that Belgrade would like to abandon this policy in favour of Berlin or Rome. The developments have again and again shown that those who calculated with such probabilities had made a mistake. Thus, for example, in spite of its endeavours to be on as close terms as possible with the Fascist Powers, Belgrade readily decided to take part in the sanctions against Italy in the Abyssinian conflict. This fact is of no small importance, as, in view of its particularly close trade relations with Italy, Belgrade made a real and serious 


\section{GERMANT PUSHES SOUTH-EAST}

sacrifice to the idea of collective security, which can hardly be compared for relative importance with that made by any other European state.

Examples of this kind again and again show that Yugoslavia, despite quite openly admitted sympathies for the Third Reich, will at the decisive moment never be in a position to make itself definitely over to a revisionist Power, especially Germany, which never entirely abandons its desire for the "Anschluss" with Austria. The penetration of Austria by National Socialism would, however, extend the Third Reich's sphere of influence to the very coast of the Adriatic.

If at the same time we bear in mind the active influence exerted on the Croats by Hungary and Italy, about which we shall speak later, it will be evident that the hostility to revision claims latent in Yugoslav policy will always gain a victory over the otherwise friendly tendencies towards Berlin shown from time to time by Belgrade.

It would, however, be a mistake to conclude from this that the push South-East, which, particularly in so far as it was directed to Belgrade, had already influenced the policy of the Hohenzollerns and Habsburgs, must needs fail merely in the face of Belgrade's necessarily hostile attitude to revisionist claims. On the contrary, there can be no doubt that Berlin does everything in its power to penetrate Yugoslavia by propaganda in the field of economic and internal politics, to separate it from the Little Entente, or at least to utilize it as far as possible as the fulcrum of National-Socialist policy within the Little Entente.

These efforts by the Third Reich would probably prove a failure in the long run, the more so as Belgrade can still play out the French, British, and Italian cards 
GERMANT PUSHES SOUTH-EAST before having to undertake the perilous adventure which Berlin desires of it. However, it cannot be concealed that the Third Reich's south-east policy seeks with extraordinary tenacity to secure a foothold here, which is of inestimable importance for the numerous problems of the Eastern Mediterranean.

When, in an official speech at the beginning of 1936 , the Yugoslav Prime Minister and Minister for Foreign Affairs, Stojadinovič, stated that the Italian-British gentlemen's agreement represents full guarantee for the Yugoslav Adriatic frontier by Great Britain from then on, authoritative declaration was immediately forthcoming from Great Britain that this is a misinterpretation of the gentlemen's agreement. So long as Yugoslavia adheres to the principle of collective security, advanced by the League of Nations, and especially keeps its two most important treaties-the Little Entente and the Balkan Entente-its position in the sphere of foreign politics is undoubtedly extraordinarily strong. Too strong even for Yugoslavia to have to give way to German pressure, its economic allurements and its propaganda in internal politics.

Nevertheless, however, the entire situation of Yugoslavia makes a transition to the front of the fascist and anti-communist states entirely impossible, as this very front consists more or less exclusively of revisionist countries, of which nearly all believe that they have claims on Yugoslav territory, or at least support such claims made by other states.

Belgrade's favourable position in foreign politics, of course, facilitates repeated attempts to play the would-be allies off against one another. The attempts, moreover, are made also in the case of revisionist states, such as Hungary and Bulgaria. The treaty 
of friendship concluded between Belgrade and Sofia at the beginning of 1937 can be regarded as an example of this. It must be borne in mind that Yugoslavia has refused all offers intended to permit the conclusion of a treaty with France similar to that existing between Prague and Paris. While unwilling to add strength to the anti-revisionist front by such a treaty, Belgrade concludes a treaty with Bulgaria which can by no means be regarded as an extension of the Balkan Entente, as otherwise the much more simple form of Bulgaria's joining the Balkan Entente, as has been so long and so generally desired, would have been chosen.

The welcome given this treaty of "eternal friendship" between Bulgaria and Yugoslavia, particularly in Rome and Berlin, proved quite as clearly as the glad consent of the head of the Bulgarian Nationalists, Professor Zankoff, that this was anything else but a strengthening of the idea of collective security. Yugoslavia evidently considered itself strong enough to conclude a purely bilateral treaty with a state which has previously baulked at all participation in collective treaties in the Balkan Entente principle.

Without over-estimating the importance of this Yugoslav-Bulgarian treaty, it may at least be considered a proof that the south-east policy of the revisionist states, particularly Germany, occasionally makes some progress.

This was still clearer in the case of the bilateral pact concluded in Belgrade in March 1937, between the Yugoslav and Italian Governments. This pact was contrary to the unequivocal terms of Article 6 of the Little Entente Pact of February 16th, 1933, which made all bilateral pacts of this kind with a state not a member of the Little Entente subject to the unanimous 
GERMANY PUSHES SOUTH-EAST approval of the Council of the Little Entente. In this case, too, it is true, approval was subsequently given at the conference of the Little Entente held in Belgrade in April 1937-though only in the form that "note was taken" of the Belgrade-Rome Pact.

On the occasion of the official visit to Belgrade of the Czechoslovak President, Dr. Edward Beneš, in the same month, the impetuous demonstrations of the populace in favour of Czechoslovakia, the Little Entente, France and democracy, showed that the dissolution of the Little Entente desired in certain quarters would probably prove impossible, as this alliance is anchorcd far too deeply in the hearts of the three nations. The fact that bilateral pacts of this kind, not registered at Geneva, are not in harmony with either the spirit or the letter of the Little Entente Pact, was made abundantly clear, and it would be wrong to overlook this fact.

When considering the line taken by the Yugoslav foreign policy it is essential to pay due regard to the situation of the country's internal politics, and to take into consideration the fact that the constitution laid down by the late King Alexander in I93 I is not in harmony with democratic principles, and not only makes the co-operation of the Croats in practice impossible, but also annuls the most important basic rights, such as the free expression of opinion in the Press, the right to hold meetings and unrestricted parliamentary franchise. After this restriction of constitutional rights, it is true, the Government promised to submit to the Skupština three laws securing, or rather restoring, these basic rights.

In point of fact, however, the three promised laws were never submitted. Opposition to this constitution I 15 
and the Stojadinovic government on the part not only of the Croats, but also of the Serbs, never ceased. Dr. Stojadinovič's attempts to bring his foreign policy more and more into line with the policy of the Berlin-Rome axis have led to a constantly increasing distrust of the régime on the part of the Yugoslav nation, whose entire mentality inclines it to hostility to dictatorships and to democratic ideas. Prague and Paris regarded Belgrade's fluctuating foreign policy calmly and without apprehension, convinced that it was not in harmony with the character of the Yugoslav nation and that a policy of "flirtations" could not lead to any change in the vital interests of Yugoslavia and its people.

Gertain points of difference between the German and Italian policies in Yugoslavia, however, now became more evident, and although Berlin formally welcomed the Ciano Treaty of March 1937, it very soon happened that Italy's trade interests in this country came into conflict with Germany.

Of greater importance to the observer of developments in Yugoslavia than the policy of coquetting with the two Fascist Powers, however, was the gradual progress of the unification of the opposition in the year 1937. The differences of opinion between the Serbian parties, which were almost completely removed by the new constitution, were gradually overcome after considerable labour in the course of the year 1937 ; after the union of the Serbian opposition the preparation of a common programme followed, which, on October 8 th, was adopted by the Croats, too, in the shape of much the most important of their parties, Dr. Matchek's Croat Peasant Party.

The now united opposition claimed in this programme the formation of a "concentration govern- 
ment", not to be joined by any party not "rooted in the nation". Further, the summons of a "Constituante" was demanded, the restoration of democratic and parliamentary liberty, and above all a foreign policy was chosen which should be fundamentally in favour of the principle of collective security, Yugoslavia's old alliances, and of a repudiation of the campaigns of the Fascist Powers.

In October I937, Dr. Stojadinovič, in compliance with wishes frequently expressed by France, affixed his signature in Paris to the prolongation of the FrancoYugoslav treaty of alliance of the year 1927 , which has to be prolonged every five years. Belgrade's foreign policy was accordingly committed to follow the line of both the Italian (i.e. also the Italo-German) and the French foreign policies; it is hard to say how these different engagements can be harmonized if there is any further intensification in the tension between the two contrasting European tendencies, which may be characterized as Paris-London on the one hand and Rome-Berlin on the other.

In any case the whole trend of events in Yugoslavia shows very clearly that the penetration of the Fascist Powers is faced by a resistance which is constantly growing. Whereas the authorities endeavour to combat the predominance of the "axis" by playing off one Fascist Power against the other-a game which, particularly in the case of Yugoslavia, is in spite of all temporary successes much more dangerous than, for example, Poland's manœuvres with its two neighbours for years past-the will of the nation is asserting itself more and more strongly : by an abolition of the dictatorial constitution at home to adapt its foreign policy to that of Yugoslavia's true allies, thus taking the 
quickest and surest method of dispelling all the distrust which has accumulated as a result of Yugoslavia's wavering foreign policy in recent years.

In the case of Yugoslavia, too, therefore, it is abundantly clear that in the end it is the character of the nation which decides the fate of the country and the direction of its foreign policy. A Yugoslavia united and strengthened on a democratic basis would in all probability not merely theoretically, but actually, fulfil its natural mission in the ranks of the democratic Powers of Western and Central Europe. By no means the least important part of this mission is that this country, which has at its disposal one of the best and relatively strongest armies on the Continent, supports the policy of peace and democracy in the same way as both the Serbian and the Groat nations did under the most difficult circumstances imaginable during the Great War.

If we do not judge developments in the Central and South-East European states merely by current events, and admit the conclusion that the character of the nations is much more permanent and of much greater importance for the foreign policy of a country in the long run than are individual incidents, it necessarily follows that the expert observer of developments in Yugoslavia sees no prospect of Belgrade's becoming Fascism's keystone in the Balkans.

On the other hand, the considerable help afforded by the inconsistent foreign policy, frequently determined by the internal political situation, to the penetration of Yugoslavia by the two Fascist Powers cannot be denied. The National Socialist régime very soon recognized the great strategic importance of the country for the pan-German thrust south-eastwards, 
and Berlin certainly did all in its power to take full advantage of the opportunities offered here.

In the final analysis, however, apart from the importance of the internal political background, it is necessary to keep firmly in mind that Yugoslavia, like the two other Little Entente states, has no interest of any kind in an alteration of the frontiers in Central Europe, so that to support the policy of the Powers which are working for a revision of the frontiers is incompatible with the vital interests of the country. These two important factors in the internal and foreign policy should never be neglected, not even if we limit ourselves to a mere registration of individual events, frequently overestimated, without paying due consideration to underlying circumstances, and consequently arrive at the conclusion that the German thrust South-East, with a certain amount of support from Italy's foreign policy, really has made certain progress in Yugoslavia.

In the case of the Little Entente states, and consequently also Yugoslavia, final success would probably not be attained, for none of these states can sell itself to revisionism without seriously endangering its entity, created by the peace treaties. It must at least be realized that even in some of these states, which are all absolutely dependent on a principle of maintenance of the status quo, the German push South-East occasionally records partial successes, which are characteristic of the impetus developed by the new German imperialism in South-East Europe. This applies to an even greater extent to those states in Central and SouthEast Europe which themselves already have revisionist tendencies and which are to a still greater extent willing to let themselves beutilized as a suitable instrument of the new German south-east policy. 


\section{Chapter VIII}

\section{A REVISION OF REVISIONISM?}

Although Western observers often consider the development of the imperialist policy adopted by National Socialist Germany in Central and South-East Europe with a certain amount of optimism, it can be seen in nearly every country lying on the old German path of expansion from Berlin to Baghdad how little this optimism is justified and even what dangers it involves. In the Little Entente states the German attempts to make preparations for war, as has already been described, occur as a chain of persistent attempts to destroy the existing treaties from within, to fill them with a new spirit, as it were, and to transform the mentality of opposition to National Socialist advance into one of sufferance or even favour, while the states which, like Czechoslovakia, oppose an inexorable resistance to the attempted fomentation of disharmony, are brought into a cross-fire of international propaganda.

If we turn from the states of the Little Entente, whose most vital interests are entirely in opposition to revision, to the two losers in the Great War situated in the South of Europe, Hungary and Bulgaria, we find that German propaganda here adopts other tactics. The slogan of a "revision of revisionism" has been thrown by Berlin into the international forum more and more often since 1936 , and the attempt was made to impress upon public opinion, particularly in the Western 
countries-though to a certain extent also in the states of the Little Entente and Balkan Entente-the conviction that Germany has no interest at all in supporting other states' claims to territorial revision.

The purpose of these tactics is to awaken in the states endangered by revisionism the opinion that in the event of a reconstruction of the fronts in European politics it would be only the German claims which would have to be discussed, and that Germany itself has not the slightest intention of laying itself out for the interests of other Powers with claims for revision. Bismarck's old phrase about the Balkans' not being worth the skin of a single Pomeranian grenadier is given in all its aspects by Berlin's present propaganda, with evident application to Hungary and Bulgaria, and the attempt is made to convince British and French public opinion as well as that of Roumania, Yugoslavia, Greece, etc., of Germany's entire disinterest in the claims for revision raised by South-East European states. Unlike Mussolini, who, speaking in Milan as recently as the middle of $193^{6}$, emphasized his understanding for the claims for territorial revision raised by his ally, Hungary, occasional statements can again and again be encountered in the German Press and even in official speeches by National Socialist statesmen, all intended to emphasize Germany's disinterest in revision, particularly in Hungary.

Circumstances are quite different, however, when we observe National Socialism's actions in the revisionist states themselves. Rather cynically, the importance of all anti-revisionist statements is denied there and National Socialist propaganda is quite openly made, with considerable utilization of revisionist theses. Reference is continually made to the fraternity of arms with 


\section{GERMAN PUSHES SOUTH-EAST}

Germany in the Great War, though so disastrous for these states themselves, and emphasis is laid on the "dynamic" principle that not treaties but rather a nation's vitality and capacity for expansion will decide its future development, and above all, open propaganda is pursued against all non-German minorities with the inevitable anti-Semitic flavour.

The support of Hungarian and Bulgarian Fascism and of the minority policy, which will be discussed later conjointly, plays at least as great a part in National Socialist propaganda in the revisionist states as in the countries of the Little Entente and Balkan Entente.

Naturally the Minority problems, always except where they concern the German Minorities, are dealt with in exactly the opposite manner, as, for example, in the states of the Little Entente. While Germany in the latter case operates as inexorable protagonist of the rights of the Minorities in the interest of weakening the central state authority, in the former case it takes up the part of the governments and parties in favour of revision, and combats the claims of the Slovak, Roumanian, and Macedonian Minorities, occasionally even those of the German Minorities, most decidedly, where they are contrary to the wishes of the revisionist governments of Budapest and Sofia.

Already in the autumn of 1934 , von Papen declared himself, in a speech which excited much notice, to be in favour of a common policy for Germany and Hungary in Central European matters, and emphasized that the campaign of revision must be pursued jointly, as Hungary suffers most acutely under the effects of the peace treaties. Even the phrase of a "shoulder-toshoulder fight", so celebrated in the Great War, was revived in this speech with reference to German co- 


\section{GERMANT PUSHES SOUTH-EAST}

operation with Hungary in the revision of the peace treaties, and von Papen emphasized that this path alone can lead to the solution of the Central European problems, as German-Hungarian co-operation was an absolute European mission.

In July 1936 the co-operation between Berlin and Budapest, which is repeatedly denied to outsiders, was clearly evidenced by the conclusion of a so-called "cultural treaty", and one can but agree with F. Elwyn Jones, * who, discussing this agreement, says that thereby Hungary has been made a spiritual colony of the Third Reich.

An important part in National Socialism's southeastern policy naturally falls to the Hungarian Press, which is in part quite unequivocally under the (by no means purely intellectual) influence of Berlin. During 1936, for example, it could be observed that the Hungarian Press campaign against Czechoslovakia set in again and again just at the moment when, for some reason or other, a temporary pause had to be made in the German attacks. Most of the "documentary material" which National Socialist propaganda submitted to the public opinion of the world in the course of its campaign against the alleged Soviet acrodromes in Czechoslovakia, is from Hungarian sources or, to be clear, the production of the Magyar Press, which received this material from Berlin for publication. Such, for example, are the celebrated maps showing the Soviet aerodromes, which the newspapers of the Reich under the Berlin "Propagandaministerium" took over from Hungarian papers. Such are the reports that from the Hungarian bank of the Danube all

* F. Elwyn Jones: Hitler's Drive to the East. V. Gollancz, London, 1937 (p. 21). 
manner of Russian war preparations on the Czechoslovak side of the river are supposed to have been observed, and many others.

Hungarian internal politics under the leadership of Gömbös, the Premier, would in all probability have ended in the establishment in Hungary of a régime of purely National Socialist dictatorship, as Berlin desired, had Gömbös, who, by the way, had long lost the confidence of the Regent, not died in Munich first. Whether Hungary's real interests would not have been much better served by an improvement of the relations between Budapest and Prague, such as was repeatedly attempted on Prague's side, than by Gömbös' attempts, which finally failed before the common sense of other, truly national, Hungarian circles, may be left undecided.

Without doubt, however, much time was lost which might better have been devoted to improving Hungary's relations with its neighbours. Slowly, however, Hungary is beginning to understand that the interests of Magyar revisionism can for Berlin never be more than a means to an end, just as the repeatedly emphasized "Nibelungentreue" of the Hohenzollerns to the old Habsburg monarchy led to the ruin of this stateentity, which Berlin used only to facilitate its push South-East.

In more than one sense Hungary today, in its relations with Berlin, has taken up the inheritance of the Habsburg monarchy, and it will be a vital question for the Magyar race whether it is today to let itself be exploited by the interests of German imperialism in the same way as the old monarchy did.

The events of the year 1937 can to a certain extent be considered as an important milestone of Hungary's 
GERMANT PUSHES SOUTH-EAST

Central European policy, as Budapest showed from this time on the earnest intention of really settling its disputes with the states of the Little Entente and to take the political consequences of the fiasco of Gömbös' policy, which may be characterized as the effort to secure a dictatorship. Not only was the struggle with Hungary's illegal organizations resumed with fresh vigour, but the wish was manifested, particularly at the autumn session of the League of Nations, to arrive at a friendly solution of the two important problems which in post-War years had brought Hungary into permanent opposition to the Little Entente.

The first of these problems was the recognition of its right to rearmament. As Hungary, unlike Germany, did not resort to a unilateral breach of the existing treaties, agreement on principle was reached at Geneva, which, of course, represented merely the approval of a state of affairs already obtaining. The Little Entente satisfied itself with Hungary's assurance that this Hungarian rearmament should under no circumstances be utilized against one of the Little Entente states.

The second problem was that of the Minorities; here, too, agreement between Budapest on the one hand and Prague and Belgrade on the other was easily achieved. Although the pestiferous atmosphere of the past decades had permitted no opportunity of calm and serious negotiations, the basis for negotiations was at once created as soon as Hungary declared that it claims no other rights for its Magyar Minorities in the neighbouring countries than those which Hungary itself allows the alien Minorities living in its territory. The situation between Budapest and Bucharest was rather more difficult, but here, too, the remaining 
GERMANT PUSHES SOUTH-EAST points of difference in the Minority question are being removed by diplomatic negotiation.

If we now ask what is the real reason for this change in Hungary's policy, the most probable explanation will appear to be that advanced by a prominent European statesman who is recognized to be one of the best experts on this problem : at one time Budapest's foreign policy was calculated to do everything possible to destroy Czechoslovakia ; today the situation is that authoritative Hungarian circles are happy that Czechoslovakia separates them from the dangerous German colossus. In point of fact Hungary has enjoyed neither political nor economic advantages of any kind from its adherence to the policy of present-day Germany.

The same applies, moreover, to Italy, which was quite incapable of taking over the large quantities of wheat which it had promised in the trade treaties of the Rome Protocols to purchase from Hungary. Dictatorship has been badly discredited in Hungary by the Gömbös period, and reference is once more being made to the tradition of Hungary's thousand years of parliamentary constitution.

A glance at the map will show, moreover, that from a purely strategical angle Hungary would in an emergency have nothing to win, but probably everything to lose, from an alliance with Germany and a continuation of the tension between itself and the three neighbouring Little Entente states.

Very similarly to Austria, Hungary has always been utilized by pan-Germanism as an efficacious instrument of its drive South-East, but experience has shown how dearly Hungary had to pay for this policy adopted by Berlin. With the gradual abandonment of romantic dreams of revisionism the possibility of Hungary's 


\section{GERMANY PUSHES SOUTH-EAST}

becoming a member of a great scheme of Central European co-operation naturally increases. But this means at the same time a strengthening of the democratic forces in Hungary itself, and the statement made quite generally by Barthou in 1934 can, mutatis mutandis, apply just as well to Yugoslavia as to Hungary : "A country's internal policy cannot be separated from its foreign policy ; those who forget or neglect this fundamental truth hardly deserve the name of responsible politicians."

Since 1937 the democratic opposition, which strives for the introduction of general franchise and a secret ballot, has begun to make very distinct progress. The pro-dictatorship forces, it is true, are still at work, and one must not be blind to the fact that large sums of money are constantly flowing by direct or indirect channels out of Germany into Hungary, in order to enable the more or less illegal organizations to prepare the return of a new "Gömbös era", which would make Hungary once more one of the most important posts in the pan-German advance-guard in South-East Europe.

In spite of these phenomena, in spite of the continued existence of the numerous factions of the Swastika, Blue Cross, and Arrow Cross in Hungary, which we shall discuss in a later chapter, it can today no longer be denied that the desire for a return to serious politics, the search for new democratic forms, and the wish for co-operation with the democratic and peace-loving Powers in Europe are gaining more and more ground with the wide masses of Hungary's population. This, however, makes the answer to the question whether, after all the sharp lessons experienced in the past, Hungary will once more allow itself, against its natural interests, to be utilized as an instrument of pan- 


\section{GERMANT PUSHES SOUTH-EAST}

Germanism, although it remains uncertain, by no means so hopeless as it appeared in the years between 1918 and 1936 .

In very similar fashion to Hungary, Bulgaria, too, is utilized by the German south-east policy for the National Socialist advance south-eastwards. In the preceding chapter mention has already been made of the pact of "eternal friendship" concluded at the beginning of 1937 between Bulgaria and Yugoslavia, the sole purpose of which from the German angle is to facilitate the detachment of Yugoslavia from the Little Entente and to arrange that, while Yugoslavia's alliance with Roumania is to be preserved, Czechoslovakia is to be replaced by states more accommodating to German wishes and with as anti-Russian an attitude as possible.

Bulgaria is today perhaps the most important centre of National Socialist propaganda in the Balkans, and failing a German Minority in this country worth mentioning it is the social movement of Professor Zankoff, which under constant supervision from Berlin represents the interests of German National Socialism in Bulgaria. Professor Zankoff displaced the decidedly Left democratic régime of the Bulgarian Peasants' Party by a coup d'état as early as 1923. There were repeated changes of government, as the King frequently showed understanding for the true interests of the Bulgarian nation.

Nevertheless, however, leading politicians of Zankoff's party remained almost permanently in high places and occupied above all the important ministries in spite of frequent changes of Cabinet, and it was not until the autumn of 1936 , shortly before the point at which a purely Fascist Constitution was to be forced 
GERMANT PUSHES SOUTH-EAST on Bulgaria, via terrorist elections on the National Socialist pattern, that King Boris decided to do without the co-operation of Zankoff's ministers in the Government.

It would be a great mistake, however, to see in this act the final exclusion of Zankoff's National Socialist Party from Bulgarian politics. On the contrary, there followed the pact of friendship with Yugoslavia, which has already been mentioned, at the beginning of 1937 , which was greeted by Zankoff, who at this time hurried home from Berlin, with the greatest joy. The only difference between the Bulgarian régime with its strongly National Socialist tinge and the Third Reich is at most in the fact, often emphasized by many writers, that an expressly anti-Scmitic legislation was not introduced into Bulgaria even by the Zankoff party.

The explanation for this fact is, however, the very simple one that the Jewish element in Bulgaria is quite negligible and that Berlin has considered it more efficacious, for reasons of propaganda, to embody several large Jewish tobacco interests in the Zankoff movement. This, too, provides a particularly eloquent proof of the fact which can be noticed again and again in connection with the new German south-cast policy, namely that National Socialism puts up with any ally without consideration of his ideology if he can in any way serve to help it to achieve even the slightest progress towards its real goal, the disintegration of the South-East European states and the final advance of German imperialism along the line Berlin-Baghdad. 


\section{Chapter IX}

\section{BERLIN AND THE BALKAN ENTENTE}

The Balkan Entente, the foundations of which were laid on February 9th, I935, in Athens, follows-like the Little Entente-the aim of pursuing an antirevisionist policy and of maintaining the status quo in the Balkans. The members of this alliance, that is Yugoslavia, Roumania, Greece, and Turkey, acknowledge in their foreign policy the principle of collective security and of the League of Nations.

This in itself already involves, on the one hand, natural opposition to all those forces that wish to shift frontiers in South-East Europe, and therefore particularly to the National Socialist push South-East; on the other hand, it involves the comprehensible endeavour, on the principle "the Balkans for the Balkan nations", not to let themselves be made into an instrument of the imperialist desires of certain great Powers in the way which characterized the years preceding the Great War. National Socialism would encounter here too, as in the case of the members of the Little Entente, resistance arising out of the will-to-live of the states concerned, if it ever openly claimed a co-ordination of the foreign policy of the members of this alliance with Berlin's. Here, too, National Socialism consequently saw its chances mainly in disintegrating the states in question economically and in their internal politics, playing off political parties against one 
another and above all supporting, morally as well as financially, all endeavours aiming at a replacement of democratic forms of government by dictatorship.

In the case of the Balkan Entente it must first be considered that its two most important members, Roumania and Yugoslavia, are at the same time members of the Little Entente. Any economic or political successes gained by National Socialism in these countries would accordingly not only serve the important purpose of isolating Czechoslovakia, but at the same time would also lead to the dissolution of the Balkan Entente, which is of an essentially antirevisionist character. This, therefore, is a further explanation for the fact that the centre of gravity of National Socialism's south-east policy is to be sought just in these two countries. The marshalling of the right wing of the Fascist and anti-Semitic opposition of Roumanian terrorist groups (to be discussed later) is aimed primarily at the detachment of Russia from Czechoslovakia and thus at the elimination of the strongest military Power of Eastern Europe, which might use its resources for the maintenance of the status quo in the south-eastern part of the Continent against the National Socialist advance south-eastwards.

The support of the Yugoslav Minorities and the effort to separate Belgrade from the Little Entente, if at all possible, and make it dependent on Berlin, is, on the other hand, directed towards weakening any position of British predominance in the Eastern Mediterranean. To this end Berlin gladly takes into the bargain even a strengthening of Italy's interests, as it is evidently convinced that, owing to its financial and colonial problems, Italy would hardly be in a position to resist German expansion in Central and South-East Europe. 
Great Britain, on the other hand, is dreaded as a dangerous antagonist in a conflict, as its position in the Eastern Mediterranean is very strong despite the Abyssinian happenings, because the National Socialist advance in the Danube Basin, directed towards Asia Minor, must sooner or later be considered by London as the danger for the Empire which the National Socialist south-eastern policy actually is.

From this point of view it is possible to understand the constantly renewed efforts of Berlin to mitigate, and finally remove, the differences between Rome and Belgrade. The part of an "honourable intermediary" played here by Germany as an ally of Rome, and a state with more or less friendly feelings towards Yugoslavia, is aimed directly against the British position in the Eastern Mediterranean. It is more and more obvious that Berlin's object is to keep Great Britain busy securing the sea-route to India, the artery of the Empire, and thus distracting British foreign politicians' attention from securing the land-route to Asia which leads from the Baltic along the chain of small states to the shores of the Black Sea.

Germany's participation in the Spanish adventure in 1936 and 1937 can only be correctly understood if viewed from this angle, as Germany's actual interests in the Mediterranean are more or less insignificant compared to those of Great Britain, France, or even Italy. The significance of Germany's interest, especially in the Eastern Mediterranean, becomes clear when it is realized that it is probably of the greatest consequence to the German south-eastern policy to tie down the Great Powers in the Mediterranean and thus to gain the "free hand" on the south-east route to Asia by land, which is today the main nucleus of the entire German 
imperialism, as it was in the era of the Hohenzollern pan-German policy.

What has been said here of Yugoslavia applies, with certain modifications, to the other members of the Balkan Entente as well, that is Greece and Turkey. As we will show later, a very important stronghold has already been secured here by methods of economic penetration; the large claims which these states have in consequence of the system of clearing-accounts with Germany imposed on them serve the purpose of accentuating still further their dependence on Germany. In spite of the traditional ties of friendship between Greece and Great Britain, under Metaxas's régime, which is a dictatorship on the National Socialist pattern, Germany succeeded, by its economic tactics and National Socialist propaganda, in installing in nearly all the leading positions of Greek political life personages who in their entire political and intellectual principles sympathize with National Socialism.

After the creation of the Balkan Entente in 1935 its four members not only guaranteed one another an unconditional recognition of their frontiers and in fact of the entire status quo on the Peninsula, but, in addition, pledged one another not to enter into alliances, or conclude treaties of any kind, with a Balkan state which is not a member of the Balkan Entente (i.e. Bulgaria and Albania), without having previously secured the consent and adequate co-operation of the other three partners.

The far-reaching importance of the treaty of "eternal friendship" which Yugoslavia concluded with Bulgaria at the beginning of 1937 can be grasped only if thisperhaps the most important-clause of the Balkan pact of February 9th, 1935, is taken into account. Bulgaria was defeated not only in the Great War but also, as is 


\section{GERMAN PUSHES SOUTH-EAST}

well known, in the Second Balkan War, still earlier, by its neighbours; it would be a dangerous mistake to assume that, unlike Hungary, Bulgaria has left the ranks of the revisionist states.

The entire complex of developments, particularly that of the Macedonian question since the Great War, clearly shows that Bulgaria raises claims to revision against Yugoslavia, Greece, Turkey, and Roumania. The conclusion of the Yugoslav-Bulgarian treaty in 1937, on Germany's and Italy's instigation, means that Bulgaria had abandoned revisionist claims against the West in order, naturally, to concentrate all the more on the claims against its other neighbours, who are all members of the Balkan Entente.

There can be no doubt that the Bulgarian-Yugoslav pact is incompatible with the Balkan Entente and even the League of Nations. The pressure applied by Bulgaria on its neighbours with a view to obtaining territorial revision has up to now in practice, and in comparison with that of Hungarian revisionism, for example, been relatively insignificant, for the country has been considerably enfeebled by its two defeats, and further its claims are almost equally distributed over not less than four neighbouring states. To maintain this state of affairs by preserving the status quo in the Balkans was the real purpose of the treaty of 1935 .

The revisionist pressure applied by Bulgaria, whose foreign trade is to more than fifty per cent in German hands and whose policy, in spite of all changes in the Cabinet, is always firmly ruled by the Zankoff partythe Bulgarian variety of National Socialism-will probably in future be directed more and more against the other members of the Balkan Entente. Sofia has no similar treaty with them, and the conclusion of such 
bilateral treaties would have been quite absurd, for Sofia was free to join the Balkan pact at any time, if it would have participated in the guarantee of the preservation of the existing Balkan frontiers.

Consequently Greece and Turkey, too, clearly feel the increase in the revisionist endeavours brought about by Berlin with the aid of other states. Considerations of foreign policy would therefore make it entirely impossible for Greece to adapt itself to National Socialism's south-eastern policy, as Bulgaria's desire for revision, fortified by Germany and Italy and undoubtedly not mitigated by the treaty with Belgrade, must be automatically vented in the direction of the Egean.

If Greece, in spite of this fact, enters into still closer relations with Berlin, the reasons, just as in the case of Roumania and Yugoslavia for example, lie in economic considerations and in internal politics. Without the co-operation of German National Socialism it would have been impossible for Greece to abandon democracy and introduce a dictatorship, working with all Berlin's and Rome's usual methods to maintain its predominant position ; were Germany to lose interest in the maintenance of the present constitution in Athens, it would very soon lead to an awakening of the democratic forces in the country and an abolition of the dictatorship, which has no solid footing in the Greek nation. On the seizure of power by the dictator, Metaxas, democratic and liberal politicians in Greece were put under arrest on the strength of the slogan of "a suppression of the communist revolution", and thus for Greece a foreign policy dictated purely by the interests of the nation was made impossible. The decisive feature of its foreign policy remains solely the endeavour to preserve the dictatorship founded on August 6 th, 1936 . 
GERMANT PUSHES SOUTH-EAST

The leaders under this régime, however, are almost without exception men who are indebted for their political career to National Socialist support. In Greece the methods of the National Socialist south-east policy have proved a success, for, regardless of the actual interests of Greek foreign policy, considerations of selfpreservation leave the Hellenic dictatorship no alternative but close alliance with German National Socialism. Berlin's acquisition of this further important foothold in the Eastern Mediterranean can be regarded as the fruits of this policy. Just as under Wilhelm II panGermanism utilized Austria-Hungary merely as an instrument of the intended advance south-eastwards, without any regard for the really vital needs of this state-entity, so Greece under Metaxas's dictatorship is transformed more and more into an instrument of National Socialism's Balkan policy, contrary to its own vital interests.

It is interesting to be able occasionally to find that Berlin is fully aware of the clashing of interests of a Balkan nation and the dictatorship which it has helped into the saddle and which, for the sake of the National Socialist south-east policy, it continues to support to the best of its ability. Thus Othmar Krainz, for example, in his book Hexenkessel Donauraum, after describing in detail the seizure of power by Metaxas's dictatorship and the necessity of abolishing the democratic régime in Greece in consequence of the "communist danger", admits relatively frankly :

Since August 6th, 1936, Metaxas rules in Greece as a dictator. He has not yet been in a position to prove that the masses of the Greek nation stand behind him. It may be that now they will place thernselves behind him. 
GERMANT PUSHES SOUTH-EAST

In Greece, National Socialism successfully and with the same slogans pursued almost exactly the same policy as it did in the other South-East European states and in Spain. As in all other cases, the main motive here was merely to facilitate and prepare the German push South-East and the realization of the old dream of the foundation of a rich colonial empire on the Continent, stretching from Berlin to Baghdad. Suitable methods can always be found, according to the structure of the state in question and its population, to paralyse the natural resistance of the South-Eastern states to the German plans for expansion, or at least to use them, even against their own interests, as an instrument which can be turned to account at a convenient time to ward off other Great Powers from the south-eastern line of advance which Berlin is developing.

The resistance in the fourth state of the Balkan Entente, Turkey, has up to now, however, been considerably greater, as British politicians in time found ways and means of awakening the resistance of Kemal Pasha's state to German attempts at penetration. The great importance of this state for European politics, even if only by virtue of its possession of the Straits and as a gateway to Asia, has of course made it, too, an ardently coveted object of National Socialist propaganda, especially in economic fields. In spite of the fact that Berlin's influence occasionally increased considerably even here, this position will probably prove anything but easy to gain, the more so as the method of disseminating dissension in internal politics evidently fails here.

Bearing in mind the tenacity of National Socialism's endeavours to win over South-East European states, it can hardly be expected, however, that Germany will 
completely abandon its attempts to gain political influence in Ankara and then to strengthen it to such an extent as to be able to utilize Turkey as one of its bridges to the heart of the British Empire in Asia. The methods of National Socialism's policy of penetration in these states frequently prove efficient even when Western observers assume that they have definitely failed.

Even though conditions in every country are different, it will be necessary to watch carefully the National Socialist south-eastern policy not only in Turkey, but also in all its other fields, if the old dream of the line Berlin-Baghdad, which gave rise to the last World War, is not to lead to further dreadful explosions at a convenient moment. There can be no doubt that such an explosion would by no means be confined to Central and South-East Europe only. It would endanger the existence, not only of the small and medium states in the Danube Basin and Balkan Peninsula, but perhaps also of this or that Great Power.

Today the German south-east policy calls for watchfulness to a far greater degree than in the years preceding the Great War. In its new "national" and "social" form German imperialism does not limit itself to the usual diplomatic methods of former times, but operates with a most dangerous and variable system of disintegrating the trade and internal politics of the states over which it wishes to gain influence. It is just these methods of economic penetration which in most cases indicate the beginning of a policy of an unrelaxing grasp, the object of which is to force the states in question entirely under the influence of the German policy of expansion. We shall now deal with these methods of economic penetration. 


\section{Part Three}

German Economic Strategy

in the South-East 



\section{Chapter $X$}

THE THIRD REICH'S METHODS OF OBTAINING FOODSTUFFS AND RAW MATERIALS

Germany's economic thrust South-East has two roots. On the one hand, in order to be able to continue its enormous armament programme, which would be far beyond the economic and financial resources of the country itself, the Third Reich requires an additional import of numerous products which it can only purchase from countries which are willing to sell their goods as far as possible entirely, or at least partially, without normal payment in foreign exchange bills. On the other hand, the enormous purchases of foodstuffs and certain raw materials which are made on certain fixed lines in Central and South-East Europe have the purpose of facilitating economic penetration of these states; this is to serve at the same time the intended political propaganda of National Socialism and, consequently, the advance planned by German foreign policy on the line Berlin-Baghdad.

As far as the actual question of requirements is concerned, the progress of the programme of armament is accompanied by more and more forcible allegations from Germany that it is being "crowded out" of world trade by being prevented from obtaining the foodstuffs needed for feeding its population and the raw materials needed for export, and in particular for the complete elimination of unemployment. In spite of all the 
promises that in a few years Germany will be completely self-supporting with regard to the supply of foodstuffs, and that the Four Years Plan set up on January 3oth, I937, will secure Germany's independence of foreign raw materials, the demand for the allowance of credit for foodstuffs and raw materials is almost exactly as old as the Third Reich itself. Since I937, in particular, the reason for this claim has been given as the statement that Germany has been robbed of its colonies and that this is the main reason why it is not in a position to obtain the necessary raw materials, etc., for its economic system to the same extent as previously.

The argument is advanced that during the period of economic depression, particularly since 1933, in other words after National Socialism's seizure of power, considerations of a purely political character had led to so effective a process of "crowding out" that without international help, that is without the grant of credits and colonies, Germany is absolutely unable to return to normal methods of obtaining supplies of foodstuffs and raw materials. The scarcity of raw materials and foodstuffs is alleged to have forced Germany, as it were, to become self-supporting, and it is said that it now lies with the great economic Powers to give Germany once more the possibility of covering its requirements of the necessary products in a normal manner.

In order to investigate this thesis we must start by asking what, then, is considered to be Germany's normal supply of foodstuffs and raw materials. It is certainly a very liberal concession if we go back to 1929, the summit of the boom, a year in which Germany's trade was indubitably in a position to import enough raw materials and foodstuffs to participate in 
GERMANT PUSHES SOUTH-EAST the international trade boom by exporting finished goods, to keep its economic system going and to feed its population. If we consider the official figures of the German trade statistics, which J. Turner has taken as the basis of his excellent little analysis Hitler and the Empire, we see, however, that since I929 Germany's supplies of the most important raw materials not only have by no means decreased, but actually have been quite considerably increased. The entire net import of copper ore, zinc ore, lead ore, tin ore, manganese ore, metallic copper, zinc, and aluminium amounted in 1929 to $\mathrm{I}, 265,000$ tons.

It is best here to consider the imported quantities and not their value, as the ore and metal prices on the world market have since fallen considerably. In 1935 the corresponding import figure was already $\mathrm{I}, 245,000$ tons. The import is therefore only negligibly-a round $2 \%$-less than the quantity imported in 1929 . In point of fact there can be no question even of this negligible decrease in the supply of metals, as from I 929 to 1935 the inland production of copper, lead ore, zinc ore, and aluminium rose from 268,000 to 304,000 tons metal content. If we add its imports of nonferrous metals to the domestic production we find, therefore, that by 1935 Germany was not only just as well, but actually better supplied with these important raw materials than in the year 1929, the peak of the boom. Since then this branch, as well as the supply of iron, which attained record figures in 1936 , has made a further improvement.

The situation is similar in the case of all other important raw materials - rubber, for example-where the 1935 imports exceed the r 929 figure by $46 \%$, and crude petroleum, which showed an increase of $43 \%$ 
in the slump years. In the case of crude petroleum, moreover, the inland production has increased by more than $300 \%$; in the case of textiles, it is true, the total imports amounted to $75^{1}$, ooo tons (of wool, flax, hemp, jute, cotton, etc.) in comparison with 740,00o in 1935, but here the prodigious increase in the German production of substitute textiles must be considered, which more than amply compensates for the decrease of only $\mathrm{I} \frac{1}{2} \%$ in the import of natural textile fibres.

In the analysis previously mentioned Turner states that the German production of artificial silk alone rose from 26,472 tons in 1929 to 55,000 tons in 1935 , or in effect was increased by more than $100 \%$. In addition there is the production of staple fibre, moreover, which in 1929 was almost non-existent, and is given as 15,000 tons in 1935 .

Even if we pay no attention to the increase in the German domestic production of less important textiles, such as flax, these figures show clearly that in 1935 Germany had at its disposal a very much larger supplement to its own stock of raw materials than in the boom year i929. What has been said here, on the basis of a few figures, regarding the most important groups of raw matcrials, such as ores, ferrous and nonferrous metals, rubber, petroleum, textile fibre, etc., applies at least to the same extent to nearly all the other raw materials, so that the allegation of a poverty of raw materials finds no backing in fact.

This increase in the German imports and domestic production of raw materials continued in 1936, moreover, in spite of the rising tendency of world prices. To give a few examples only: the Economist, in its "Commercial History and Review of 1936", gives Germany's consumption of rubber as 72,000 tons in 
I 936 as compared with 63,000 tons in 1935, while of metals the same source gives, for example, an increase in the consumption of lead from 170,000 to 200,000 tons, of zinc from I95, 000 to 2 I o, 000 tons, and an increase in the export of British coal alone to Germany from $2,884,905$ tons in 1935 to $3,047,582$ tons in 1936 .

These figures have a very special importance for the colonial claims to be discussed later; they might be supplemented by a long series of similar data, all demonstrating that Germany's supplies of raw materials are not only not inferior, but actually considerably superior, to those for the boom year I 929 , and that the domestic production too, by virtue of a considerable increase, supplements the rise in the imports ; thus, for example, the present German production of crude petroleum is 430,000 tons annually, compared with about 230,00o tons before Hitler's seizure of power. This state of affairs has been discussed at this point in order to show that the allegation that Germany is suffering from a lack of raw materials is entirely at variance with the facts.

If we now ask how this evidently ample, and even more than ample, supply, in such contrast to Germany's alleged scarcity of raw materials, has been obtained, it must be emphasized that, firstly, it wasindubitably not an increase in the German exports which created such a surplus of foreign exchange bills for purchases of raw materials. On the other hand, it can be demonstrated that Germany's reserves of currency, a considerable proportion of the national capital, have been consumed for the purpose of continually increasing the imports of raw materials, for not only have the Reichsbank's stocks of gold and foreign exchange bills decreased to a fraction of the 1932 level, but also its 
foreign investments have to a considerable extent been disposed of, and that at decidedly low rates, returning to Germany in the form of raw materials.

At least as important, however, is the deterioration of the food situation, resulting from the decrease in the import of important foodstuffs, particularly fat, so that a further important proportion of the maintenance and even of the very considerable increase in the supplies of raw materials since 1933 was paid for by a depreciation in the standard of living - in other words by the hunger of the people of Germany.

But even these circumstances would by no means be sufficient to enable Germany, without money or credit, to continue to import the prodigious quantities of raw materials which are needed for the development and supply of the German war industry and at the same time to prevent too serious a fall below the minimum standard of living of the German people.

The third, and perhaps most important, method by which such ample supplies of raw materials for the war preparations have been made possible comes into action here : the activities of the German trade policy since 1933. Here we find how close is the economic connection with the political thrust South-East which is characteristic of the régime which has ruled in Germany since I933.

It must first of all be realized that the countries of Central and South-East Europe suffered particularly acutely under the effects of the economic depression and the fall in the world market prices.

On the one hand, in many cases it was absolutely impossible to place their agricultural produce on the world market, for even for the highly qualified and standardized qualities of overseas grain and other 
agricultural produce the market was so unfavourable that they could find buyers only at figures lying below the cost price. On the other hand, the financial indebtedness of most of these states, in consequence of the numerous public loans and short-term credits granted them after the War and in the boom period of the 'twenties by Western Europe, America, etc., had become so great that there was absolutely no possibility of their obtaining the most necessary articles of consumption produced by foreign industry, such as textiles, leather goods, agricultural implements, etc., against cash payment.

This is where Germany came in, and the trade strategy of the German Minister for Trade, Dr. Schacht, really managed to reserve these countries' production of raw materials and foodstuffs for Germany, or rather for the continuation of its armament programme, without giving the corresponding counter-values. Originally Germany belonged to the most important sources of supply of the South-East European states, which purchased in particular the mass production of German industry, cheap as well as medium qualities, such as ready-made garments, shoes, furniture, household utensils, agricultural machinery, etc., and as these unceasing German deliveries amounted to more than the Balkan States' sales to Germany, until the economic depression and even up to the time when Dr. Schacht's new methods were first put into effect German trade enjoyed good credit in these countries. Germany had therefore straight away the possibility of increasing its imports from the South-East without at first encountering any distrust in these markets.

In addition, Germany very soon, at the time of the greatest price-cutting, offered to take over raw 
materials and foodstuffs of inferior quality which could not be placed elsewhere. The ceaseless flow of these German imports from the South-East states soon, however, necessarily led not only to the disappearance of Germany's surplus of exports, but on the contrary to the transformation of these states from debtors into creditors of the Third Reich.

A true system of cash payments between Germany and the South-East countries had long been impracticable, and the commerce was settled by barter over clearing and compensation accounts. Subsequently, in consequence of Germany's ever-increasing purchases on credit from all the world, there was an enormous increase in the debts which the foreign creditor countries had to allow to remain outstanding in Germany. There was, however, the difference that countries like Holland and Great Britain, in consequence of their very favourable balance of trade, were temporarily able to suffer the "freezing" of such debts without any considerable inconvenience.

The situation was quite different, however, in the case of the Central and South-East European countries, particularly the Balkan States, where a regular transfusion of blood, one may say, set in towards Germany. Larger and larger parts of the national wealth of these agrarian countries, which were poor to start with, were transferred to Germany via exports of goods, and the prospect of obtaining foreign exchange bills or even merely such goods as the people of these countries actually required grew smaller and smaller.

The result of Germany's quite one-sided indebtedness was that the much better situated debtor was able to dictate to the more and more impoverished creditor what goods he might take to settle the debt, and what 
prices were to be paid therefor by the South-East European customer to the German supplier. According to a statement printed by the Financial News in the middle of 1936 , Bulgaria's frozen claims against Germany had already reached the value of 10,000,000 marks, Roumania's i 8,000,000, Yugoslavia's 2 I, 000,000, Hungary's 25,000,000, and Greece's as much as 30,000,000 marks, so that not less than one-fifth of all the frozen debts in Germany fell to these five SouthEast European countries alone.*

Quite apart from the purely economic side of this question, which undoubtedly contributed considerably towards increasing the depression in this part of the Continent, we must not neglect the political side of the straits into which Dr. Schacht's trade strategy brought the South-East European states. For it must be clearly realized that in all these countries, which depend almost exclusively on their agriculture, it was not the peasant, the tobacco-planter or the small wood-owner with whom Germany contracted. On the contrary, in practice the process was that the SouthEast European states took over the produce of their peasants, etc., in order to ship it to Germany, where the resulting debts "froze".

* To give only a few examples, Germany's percentage share of the Yugoslav imports rose from I3.I\% in 1933 to $26.7 \%$ in 1936 , while during the same period its share of the Yugoslav exports increased from $13.9 \%$ to $23.7 \%$. In the same period there was an increase in Germany's share of the imports into Greece from I0.I\% to $22.3 \%$, and of its exports from $18.3 \%$ to $35.1 \%$. In $1929 \mathrm{Ger}-$ many's share of Bulgaria's imports already amounted to $22.2 \%$, and by 1935 it had increased to $53.7 \%$, while in the same period its share of Bulgaria's exports rose from $29.9 \%$ to $48.1 \%$. In 1936 a further increase of Bulgaria's exports to Germany (by $62 \%$ ) could be noticed. In the year 1936 Greece's exports to Germany increased by a further $29 \%$, Hungary's by $32 \%$, Yugoslavia's by as much as $109 \%$ over the 1935 level. 
The real sufferer was therefore the South-East European state, whose position as creditor brought it more and more into subservience to Berlin. On the other hand, the Balkan peasants, who did not understand the real connection, or at least only partially and at a very late stage, were overjoyed to find somebody who would buy their goods. They received cash from their governments, direct or through co-operative societies, etc., and the prestige of Germany, which, using the methods of Dr. Schacht's trade policy, systematically worked for the impoverishment of the South-East European countries, rose considerably with the peasants of the South-East. The constant rise in Germany's prestige with the peasant population of these countries, which in point of fact was achieved solely through Belgrade, Budapest, Bucharest, Athens, etc., having granted the Third Reich governmental credit which subsequently became unrealizable, has become a political factor of inestimable value.

This popularity of the German purchases continued to contribute largely towards compelling the SouthEast European governments to make more and more shipments through the clearing accounts at prices which were dictated to them. If they had refused to continue these transactions, the opposition in their own country would have been considerably reinforced, and, moreover, the last hope of ever getting back any part of the frozen claims against Germany would have been lost. The rise in the prestige of the National Socialist Government of Germany with the peasants, and the dependence forced on the South-East governments by Berlin, were the two great political successes of the German trade strategy.

Thirdly, the utilization of these methods led to a 
GERMANY PUSHES SOUTH-EAST practical exploitation of the dependence into which the South-East had been brought, for Germany forced the agrarian South-East states to adapt their agriculture to the cultivation of those products, such as, for example, the soya bean, which Germany particularly needed. This further increased the dependence of the agrarian Central and South-East European states on Germany, as in many cases these products were only with difficulty-or, more often, not at all-to be placed on the world market against payment in foreign exchange bills. Very large cultivable areas were devoted to fodder plants, which had previously been cultivated only in Eastern Asia, and Germany took over the fruits of this cultivation without paying foreign exchange bills to the countries in question for the utilization of these areas.

This whole system, which was extended more and more, can only be compared with a noose thrown by Germany around the neck of the South-East European states and their peoples. The tighter this noose was drawn, the more pronounced was the position of dependence, even politically.

It should be added, however, that Germany by no means confined itself to exploiting the agricultural possibilities, and that the Third Reich's trade strategy devoted its attention, particularly since 1934, primarily to the great raw material possibilities, by trying from all sides to get nearer and nearer to the great chain of raw materials stretching from Hungary right out to Persia. Germany is separated from this chain of raw materials mainly by Czechoslovakia and Austria, which are states of preponderantly industrial significance.

These two states are felt to be a hindrance not only economically, but also politically, and the National 
GERMANT PUSHES SOUTH-EAST

Socialist thrust directs itself with particular force against them. For if Germany is successful in piercing the obstacle presented by these two states, which themselves hardly can, or wish to, effect any considerable supplies of raw materials to Germany, it almost achieves the possibility of developing a gigantic SouthEast colonial empire, reaching far out to Asia, commanding enormous treasures of raw materials; this would enable Berlin to realize the intentions expressed in Hitler's Mein Kampf, and to develop a great empire economically independent of the rest of the world.

This thrust south-eastwards aims at creating a large, economically independent empire, with claims to a position as world power, on the line Berlin-Baghdad dreamed of already decades ago. It will be shown later that this thrust must necessarily lead to a clash of interests with the other Great Powers, which gained economic successes of their own here many decades ago, or which, like Great Britain in particular, would have every reason to protect the heart of their own empire from the shock of such a thrust.

The inseparable entanglement of politics and trade in South-East Europe will be realized at this point, and memories arise of the all-Germans' many similar attempts with their "Mitteleuropa" plans by such as Naumann, etc., which finally came into the inevitable conflict with the World Powers which subsequently discharged itself in the world conflagration of rgr4. The National Socialists' methods of trade strategy in the South-East are only a part, although a very important one, of pan-German imperialism, previously represented by the "all-Germans", and today, although under many different names, resurrected to the peril of world peace in the form of National Socialism. 


\section{Chapter $X I$}

GERMANY'S ECONOMIC POLICY AND ITS EFFECTS ON THE STATES IN SOUTH-EAST EUROPE

UNDER the influence of the German landed proprietors, who were in favour of duty-protection, a constant falling-off in Germany's imports from Central and South-East Europe could be noticed, especially in the years immediately preceding Hitler's seizure of power, when the East-Elbe districts gave the tone to Germany's foreign and trade policy, but the situation altered very quickly after the change of direction. The idea of developing a chain of raw materials and agricultural produce for Germany's needs along the line BudapestBelgrade-Bucharest-Sofia-Istanbul and of drawing from here the large reserves required for the future armaments had certainly gained importance by the year 1933. Germany's imports from the states lying along this line amounted to 64.87 million marks in the first half of 1933 and they rose to 75.37 million marks in the first half of 1934 . In the corresponding period of 1935 the value of Germany's imports from these countries was as much as 90.98 million marks, and in I 936 had already reached 132.83 million marks.

This large increase in Germany's purchases at a time of the continual impoverishment of Germany's economic system and of the deterioration of the German exchange situation was made possible only by the methods which have already been described, that 
is that Germany accepted higher prices without complaint, but, on the other hand, imposed on the South-East European states terms of payment favourable to itself. The high prices figured on paper in the compensation accounts, which showed an everincreasing balance in favour of the South-East European states.

Following Schacht's method, Germany's purchases were by no means determined by its momentary needs, but on the contrary it bought any and all raw materials and provisions which it was at all possible to procure on a compensation basis. If we examine these methods there can be no doubt that from the very outset the intention was not to pay for the goods imported from South-East Europe and systematically to utilize the frozen claims accumulating in Germany in order to increase more and more the economic (and political) dependence of the countries concerned on Germany.

Berlin frequently asserted that the intention was that, in payment for the South-East European commodities, machinery and equipment were to be supplied, which could open up the great land treasures especially of the Balkan States ; but this too was planned purely in the interests of Germany's supply of raw materials. The various contracts concluded on this occasion always revealed Germany's endeavour to procure, among others, such raw materials as up to then had had to remain unutilized for lack of technical equipment. These raw materials, too-and in some cases there were quite considerable and often underestimated quantities - were, if possible, all to be placed at the disposal of Germany's armament programme without any return being given. 
The motive for the acquisition of these concessions here by the Germans was consequently not the aim encountered so frequently in economic history of raising the economic and financial level of the countries concerned, and thus also their populations' standard of living, but solely an extension of the possibilities of exploitation, in order that the natural economic resources of these states might be utilized for the sole benefit of German preparations for war.

Hardly any further proof is necessary to show that against this enrichment of Germany's economic system, which, moreover, benefited not the German nation itself, but merely the armament programme, a corresponding process of impoverishment was in progress in the Central and South-East European countries, as they had subjected themselves to this special method of colonial exploitation.

The old principle that economic relations can in the long run be developed only to the equal benefit of the interests of both parties was abandoned by Germany entirely, at least since i 933. Huge quantities of Central and South-East European grain, tobacco, attar of roses, and numerous other agricultural produce, which at the moment were less urgently required than foreign exchange bills, with which it was possible to purchase certain special raw materials overseas, were sold by Germany on the world exchanges. These sales were effected for German account and for the enrichment of Germany's stock of foreign exchange bills. The goods which Germany did not and would not pay for were sold to other parties, and the proceeds were kept.

In private life the true nature of such transactions is 
sufficiently well known to the courts, and they are adequately condemned by judges in all countries where loyalty and good faith form the foundation of the system of justice. In international commerce Germany found no judges adequately to classify this procedure. Quite apart from all juridical and moral problems, from a purely economic point of view we may say here that a large number of states, whose population lived in a constantly growing degrce of poverty, were continually being robbed of their values for the benefit of Germany's armaments. As a result of Germany's forced sales on the international commodity exchanges the market prices of Hungarian wheat, Yugoslavian maize, Greek, tobacco and Balkan grain of all kinds were naturally kept at a low level, so that the South-Eastern states' possibilities of selling their agricultural produce for their own account were reduced still further.

Brazilian caoutchouc, African copper, NorthAmerican cotton, Australian wool, and Canadian nickel, as well as Swedish steel, which Germany had for years imported for its armaments and for which it had to pay almost exclusively with foreign exchange bills, were paid for with the means of the poorest nations in Europe, namely of the states in the Danube Basin and the Balkans. The wounds inflicted by these methods of the Third Reich's commercial strategy on the economic systems of the South-East European states (which were already suffering greatly under the consequences of the depression) will in all probability not be able to heal for a long time to come. It would be a great mistake to assume that one or other of the hothouse industries created in the Balkans by Germany's compensation deliveries, or the use of large areas in I 56 
South-East Europe for the cultivation of soya beans, could compensate this.

On the contrary, this is the very thing which renders the transition of the Central and South-East European economic systems from the depression to a period of increased prosperity extraordinarily difficult, and will maintain the condition of impoverishment in the South-East disproportionately long, in spite of the rise in world prices.

This is the best possible thing for the interests of the German economic and armament policy. The Third Reich, which had exhausted its own reserves to the maximum degree even in peace, and, under the slogan "Rather Guns than Butter" financed most of its preparations for war out of the German people's resources by a reduction in agricultural wages and a deterioration in the standard of living, at a time when inland prices showed an increase, needs no commercial partners who, when conditions improved, might be able to take protective measures against the increasing German demands. Not less than 6o,000 hectares of land in Roumania, and much more than 30,000 hectares in Bulgaria, were given over to German concerns, especially, for example, the I.G. Farben-Industries, for the cultivation of soya beans.

Quite apart from the fact that Germany does not pay the lease of these huge areas with foreign exchange bills and that the entire cultivation of soya beans is still in an experimental stage, at least in Europe, it is necessary to realize that even if there is an international increase in purchasing power there are no world markets for soya beans outside of Germany, so that these entire areas which remain closed for the cultiva- 
GERMANT PUSHES SOUTH-EAST tion of products more easily placed on international markets will continue, economically speaking, to be excluded from the productive resources of the countries in question.

Every now and then one or the other Balkan state succeeded in freeing itself from these fetters (for instance, Roumania, with a considerable proportion of its crude oil production). These are, however, nearly always only exceptions, where the intervention of Western European interests succeeded in partially breaking through Germany's monopoly.

Generally, however, it is necessary to emphasize the fact that the harm done to the economic systems of the Central and South-East European states, especially in connection with the exploitation of their agricultural and mineral reserves, is very great. It is necessary to add that this damage has almost exclusively benefited Germany's programme of armaments, that it makes the resumption of the participation of these economic systems in the rising prosperity of the world difficult, and that it contributes towards placing countries with rich natural treasures more and more into a kind of colonial dependence on Germany.

The following figures, which are taken from official German statistics, but checked by comparison with the foreign trade statistics of the countries in question, show to what a considerable extent the volume of Germany's foreign trade with the actual South-East European states (that is excluding Austria and Czechoslovakia) has increased since the revolutionary year-i933-in spite of the fall in Germany's foreign trade with the whole of the rest of the world. 
German Imports from the South-East States (In millions of $R M$ )

$\begin{array}{llll}1933 & 1934 & 1935 \quad 1936\end{array}$

$\begin{array}{lllll}\text { Bulgaria . . } & 3 \mathrm{I} & 34 & 4 \mathrm{I} & 58\end{array}$

Greece . 53

Hungary . 34

Roumania 46

Turkey $\quad \ldots 3^{8}$

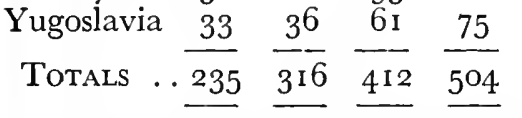

SOUTH - EAST

German Exports to the South-East States

(In millions of $R M$ )

$\begin{array}{llll}1933 & 1934 & 1935 \quad 1936\end{array}$

$\begin{array}{llll}\text { I } & \text { I } 9 & 40 & 48\end{array}$

I9 $29 \quad 49 \quad 63$

$\begin{array}{llll}38 & 40 & 63 & 83\end{array}$

$\begin{array}{llll}46 & 51 & 64 & 104\end{array}$

$\begin{array}{llll}36 & 51 & 67 & 79\end{array}$

$\begin{array}{llll}34 & 3 \mathrm{I} & 37 & 77\end{array}$

Germany's imports from these countries alone have risen from 6\% of the entire German imports in 1933 to $12 \%$ in 1936 , the exports from $3.9 \%$ to $9.5 \%$.

If we examine-which is still more importantGermany's share of these states' supplies of imported goods and the share of their total exports, we find that Germany has already obtained a share of a round $50 \%$ of the entire foreign trade of the six South-East countries mentioned. In other words, Germany's rôle in the South-East markets is now just as important for the foreign trade of these countries as that of the whole of the rest of the world put together. In individual instances, this $50 \%$ share held by Germany is actually considerably increased, for in the case of Turkey, for example, Germany's share of the entire visible exports is $60 \%$. The percentage figures are still more important than the absolute figures, because Germany's and the South-East states' foreign trade decreased exceedingly both in quantity and value under the influence of the economic depression.

Above all, however, these figures show particularly clearly to what a considerable extent the Third Reich has developed a position of economic supremacy in the South-East, equivalent to colonial power, at the cost of the other great commercial Powers. 


\section{Chapter XII}

GERMANY'S SOUTH-EAST ECONOMIC STRATEGY AND THE COLONIAL PROBLEM

IN his book Mein Kampf Hitler expressly renounced colonial demands and describes the acquisition of "room for Germany to live" in East and South-East Europe as a far more important aim, which is to replace pan-German dreams of colonial world power. In the course of the years 1935 and 1936 quite a number of the leading members of the German Government had recourse, evidently from strategical reasons, to a resumption of colonial demands. The general feeling was, however, that the newly-formulated wishes for a restoration of the colonies were not meant quite seriously, the more so as they were clearly opposed to the programme laid down in Mein Kampf which has again and again been described as unalterable.

In his speech on January 3oth, 1937, the Chancellor of the Reich himself revoked the renunciation of colonial claims and, with an unmistakably evident reference to Great Britain, demanded the restoration of the former German colonial empire, saying :

This colonial empire was taken from us. The reasons now advanced in the endeavour to excuse this seizure are not sound . . . the colonies would have no real value at all. If this is the case, then this valuelessness applies also for the other states, and it is not clear why the colonies are nevertheless kept from us. 
Many critics see in this speech an essential modification of the German policy, and considered it necessary to assume that the old dream of a colonial empire in South-East Europe on the line Berlin-Baghdad was then abandoned, as Germany thought itself strong enough to advance once more its claims as a World Power and to direct its regard to overseas territories. There is no doubt that this statement can no longer be considered as purely strategical, and there are more signs than one that Germany is endeavouring, by regaining certain territories in Africa, to threaten the line running from the Cape to the Egyptian frontier, created by the British Empire in the Great War.

It is unnecessary to say more about the danger which lies in a threat to this line, which has actually become one of the most important axes of the Empire. Mr. L. S. Amery, a former British Colonial Minister, drew express attention to these dangers in a paper read to the Royal Institute of International Affairs as early as in October 1936, and particularly mentioned the risk which must lie not only for the British Empire, but for the peace of the whole world, in the construction of submarine harbours, in the use of a gigantic native army, in the isolation of the Union of South Africa, etc.

Europe will, therefore, have to reckon with the fact that imperialist motives will probably lead more than once to the advance of this colonial claim. It is at any rate remarkable that Hitler is here in clear and quite unmistakable conflict with his original programme, and that the attempt is made to justify these claims in a relatively harmless manner, primarily economically.

Of these motives advanced for the colonial claims, 
the first and, after the National Socialist ideology, the most important, that is the claim for "room for Germany to live", is the easiest to lead ad absurdum. For in the entire German colonial empire before the Great War there lived in all only 20,000 subjects of the Reich, of which, moreover, 3000 were soldiers. Even if the possibilities of settlement may be supposed to be slightly greater today under the influence of the far better British and French colonial systems, now, as then, there can be no question of Germany's being able to accommodate any part of its surplus population worth mentioning in the colonies.

Not much better is the fate of the argument that sources of raw materials can be opened up here. On the one hand, about nine-tenths of the most important raw materials come, not from colonial territory, but from sovereign states, dominions, etc., while on the other hand a glance at the German import statistics for 1933 shows that Germany drew only about $0.5 \%$ of its requirements of raw materials and about the same percentage of its requirements of foodstuffs from the colonies.

As a market on a large scale the German pre-War colonies were just as negligible, for Germany was able to place only about $0.6 \%$ of its exports there. In the year I929, at the peak of the boom, Germany's exports of goods amounted to 12,000 million Reichsmarks. The total capacity of the entire colonial territory formerly in German hands amounted in this boom year, however, to only 240 million Reichsmarks, so that the conclusion must be accepted that in the almost impossible eventuality of Germany's completely monopolizing the entire imports of its former colonies after their restoration, this, on the basis of the figures 
for I 929 , the great export year, could lead to an increase of only about $2 \%$ in the German exports.

All the economic arguments which might be advanced for the change in Hitler's attitude to the colonial question, therefore, appear quite untenable upon close consideration. What remains is the very considerable interests already mentioned which Germany would gain strategically and politically by such an acquisition of power. To combat this part of the claims is not within the scope of this work. More important for us is the relation of the colonial demands thus suddenly advanced, which are justified on economic grounds, to the economic policy of the Third Reich in the South-East.

At this point it becomes clear, however, that all these economic justifications with which the claim for restoration of colonies overseas is accompanied really apply only for a quite different part of the world, that is South-East Europe. This part of the European Continent really does offer German imperialism areas for settlement. It also offers markets in the event of the exploitation of the great economic resources which Berlin might perhaps undertake at some later period. This could only be done, however, with some other aim than that of economic armament which today provides the motive for all its actions.

Finally, the South-East also offers a gigantic expansion of the German foodstuff and raw material base in the event of the utilization of suitable unscrupulous methods such as have already been described in a previous chapter.

German imperialism would necessarily gain an enormous increase of strength if the process of economic expansion south-eastwards were to be allowed to 
GERMANT PUSHES SOUTH-EAST continue to function. In Hungary it is necessary to mention only bauxite, which is indispensable for the production of aluminium, and of which Hungary is the most important producer in the whole of Europe. In I933 the Hungarian production of bauxite amounted to 72,000 tons, and it rose to 185,000 in I 934 and to 210,000 tons in 1935. The Yugoslav production of bauxite has about doubled its volume in the same period (from 8I,000 to I 90,000 tons). In Germany's exploitation of these gigantic bauxite reserves alone there lies a dangerous and almost inestimable acquisition of power, especially if one considers the great importance of aluminium for the construction of aeroplanes and ships.

Of Yugoslavia's other mineral treasures, Germany tries more and more to obtain possession of the important copper mines in which, however, for the time being French and British interests play a considerable part, although their displacement is being attempted. In Roumania Germany is at present already the most important buyer of petroleum and has been able to take up the leading position formerly occupied by Italy. In Bulgaria there are gigantic reserves of ore, particularly copper, magnesite, etc., and, further, there are great possibilities of Germany's forming a cotton base of its own in that country. This applies even more to Turkey, where, too, large mineral reserves can be opened up. Finally, Germany's endeavours include an extension of the chain of raw materials to Persia and its great mineral oil treasures.

From these few facts it can be seen that it would be really a mighty colonial empire which Germany would found here, if its advance south-eastwards were to be suffered. It is further evident that very 164 
important, if not actually vital, interests of other World Powers would be endangered by such an expansion of Germany, just as they were at the time of Wilhelm II and the "All-Germans". It shall be left undecided whether the importance and the practicability of the newly formulated demands for the restoration of the former German overseas colonies are being underestimated or exaggerated.

It is certain that by expansion south-eastwards Germany would gain an increase of power which would most seriously threaten the interests of the Great Powers and the peace of all the world. With time, this would necessarily create an atmosphere in which one could hardly dare even to breathe, for a united empire so rich in economic resources as that which would be created here after the removal of the AustroCzechoslavak barrier would probably by no means confine itself for any length of time to the oppression of the small nations and states in Central and SouthEast Europe. Its superfluity of energy, combined with the National Socialist ideology of pan-German imperialism, would be so great that a continuation of the thrust to the very heart of Asia would probably be inevitable.

It will be remembered that the pan-German ideology and Naumann's "Mitteleuropa" plans, like those laid down by Hitler in his Mein Kampf, were confined to the push south-eastwards in the direction BerlinBaghdad. It will also be remembered, however, that it was these attempts at expansion south-eastward that made the conflict with the other World Powers unavoidable. At the end of the "Mitteleuropa" plans there was the word "world-power"! The great efforts to build an invincible fleet with overseas bases, the 165 
GERMANT PUSHES SOUTH-EAST conflict with the Great Powers and its discharge in the Great War was the conclusion of this.

Considering today the claims for the possession of overseas colonies raised by Hitler on January 3oth, 1937, contrary to his original conception, it is difficult not to think of the period preceding the Great War. Germany's true and most dangerous claim for colonies is latent in the economic and political expansion southeastward. Only a successful attempt to check this expansion can prevent the foundation of a mighty pan-German empire from letting loose forces which later it would probably no longer be possible to restrain. 


\section{Chapter XIII}

THE BIG GUSTOMER AND HIS POLITICAL BARGAIN

When Germany effected its large purchases in the South-East European states without payment, in order to be able to carry out its armament programme in this cheap way, from the very first great care was taken to place the governments of the states concerned between the suppliers and the purchasers. The reason for this was given as the technical necessity of a programmatic development of business relations between the two parties. It would, too, in fact, have been most difficult to place the about thirty various kinds of block marks in constantly growing amounts in the hands of innumerable private persons and especially small peasants. It would have been all but impossible to regulate the rate of exchange, and the underhand trade which would have arisen in the South-East between the owners of block marks of all kinds would have exercised a severe pressure on the rate of exchange, until it became almost impossible to dispose of them.

More important than these and other technical motives were, however, reasons of political character. The governments which concluded these large supply contracts with the Third Reich, either direct or as intermediaries for the larger producers' organizations, agricultural co-operative societies, etc., were from that moment on regarded by the population as being to a certain extent responsible for the smooth settlement of 167 
the contracts. The governments which purchased the products in question in their own countries in order to deliver them to Germany consequently came into a sort of vice. Berlin insisted on greater and greater deliveries at prices and terms suited to Germany's economic situation; that is the governments had to accept in exchange inferior and expensive German products which competed with their own industries, and which, moreover, in many cases were not at all needed.

On the other hand, the South-East European peasant, and any other person who was able to sell goods to Germany on this compensation basis through the intermediary of his own government, regarded the German customer more or less as a "friend in need". For his goods, which otherwise he would hardly have been able to sell, he received from government institutions ready money, and consequently exerted greater and greater pressure on his government not only to continue to do business with Germany, but also to extend it as far as possible.

This pressure, originally of an economic character, resulting for the most part from the difficulty of obtaining a clear view of the entire compensation business with Germany, subsequently became more and more political. Germany, which constantly drew large quantities of goods from the South-East without paying for them, or at any rate without giving useful counter-value, soon formulated political conditions upon which it made the continuation of these transactions dependent. The attitude of decided friendship towards Germany taken up from time to time by the population of some of the countries in South-East Europe was utilized by Berlin with all its methods, I68 
and in many cases the governments had every reason to fear internal conflicts, unless they complied with Berlin's numerous political demands.

These demands, about which we shall speak later, referred to internal and foreign policy, to the existing treaties of alliance with other states, the treatment of certain minorities, the permission for National-Socialist propaganda, etc.

The big buyer who did not pay derived from his position as a debtor the right to formulate claims which frequently had not the slightest bearing on the conduct of the compensation business. The powerful position of Germany and of the National Socialist Party in many states in Central and South-East Europe was in this way fortified very considerably; the diplomatic service in particular was very often utilized to make and carry out these claims. While the impoverished creditor is in a critical position, the might of the debtor is growing, and it cannot be said that Germany lets slip any opportunity of utilizing its favourable position.

In many cases, for example, we encounter Germany's demand that certain groups and co-operative societies with National Socialist orientation should be given special preference by their governments as regards deliveries and payment. This frequently was the cause of the phenomenon that, in order to avoid ruin, those who wished to sell their products sought to be on as close and friendly terms as possible with those circles which were strongly favoured by Berlin or the National Socialist foreign organization. In other words, the conclusion can be reached that the Third Reich's commercial strategy in the South-East not only conjured up impoverishment for the nations and I69 
states concerned, but that, moreover, it proved an excellent instrument of political propaganda, which could be used to interfere in the internal and foreign politics of the states which themselves contributed to the loss-the so-called "freezing"-of their claims.

Here we can observe the close connection between economic strategy, National Socialist propaganda, and a purely political aggrandizement. Unfortunately, this connection is frequently not clearly perceived, and in more than one case South-East European statesmen, who were fully aware of the intent and aim of these methods used by Berlin, had to leave their posts, as the "big customer" would not permit a continuance of their guiding influence over the destiny of their country. The commercial strategy adopted by Berlin in the Danube and Balkan countries is tied with innumerable threads to politics. Only a few states had economic and political strength enough of their own to withstand this interference and entwinement of economics and politics. These are the states which had financially lost the least over the "big customer", and so were in a position to overcome the depression sooner than any other.

The system of economic and political interference in the concerns of the South-East European countries developed by Berlin is an absolute masterpiece. The dependence of the individual states and their governments on National Socialist wishes can only then be properly understood when the methods of Germany's interference in the concerns of the South-East European states are correctly recognized. 


\section{Part Four}

The German Policy of Intervention in the South-East and the Organization of National Socialism Abroad 



\section{Chapter XIV}

\section{THE PRINCIPLE OF INTERVENTION}

Absolute reserve in all questions of the internal politics of foreign countries has always been one of the principles of foreign policy, and one hardly ever abandoned by responsible governments. Since 1933 German foreign policy has abandoned this international principle, and a careful observer will be in a position to note that the methods of intervention in national differences and conflicts of internal politics occurring in the Central and South-East European states have become one of the most important weapons of Berlin's foreign policy, which in many instances proves even more efficacious than the economic propaganda which has just been discussed. German official foreign politicians emphasize that this principle of nonintervention in the internal politics and circumstances of foreign countries is recognized by National Socialism to a still higher degree than by other governments.

The main struggle contested by Berlin's foreign policy in the South-East is with "Bolshevism", and when the thesis of the struggle with Bolshevism is advanced with the aim of penetrating the internal politics of the South-East European states, mention of Russia as a sovereign Great Power is most carefully avoided.

Since the beginning of the year 1933 the term "Bolshevism" has become an extraordinarily elastic expression in the terminology of German foreign 
policy. It was first applied to the parties of the Third International, then to the Social Democrats, and finally to the bourgeois socialist tendencies and even the decidedly capitalist-liberal parties abroad ; the latter, and the principle of parliamentary democracy, were dismissed again and again as at least the "first-fruits of Bolshevism". This exceptionally elastic interpretation of the term "Bolshevism", which in international politics was used for the purpose of isolating Russia and also the Western Powers, particularly France, was supplemented at the same time by endeavours to place on the "Komintern", but in reality on Russia, the reproach that this is a force interfering in the internal development of various states with destructive effect.

A force working with such methods, it is stated, must be combated by all governments at all costs, and Russia's attempt to draw a clear line between the Moscow Government and the Third International is alleged to be only a delusion. While Moscow has been trying for years, not only to effect such a distinction between the Russian Government and the Komintern, but also to enfeeble the Komintern itself to such an extent that since about 1935 it has only vegetated, an inseparable identity is seen between the Berlin Government and the National Socialist organizations abroad, which were recognized at the beginning of 1937 under the name Auslandsorganisation der N.S.D.A.P. (Organization of the National Socialist German Workmen's Party Abroad) as a regular international organization which operates in complete agreement with the German Government in all countries beyond the boundaries of the Reich.

There is, of course, this essential difference between 
GERMANT PUSHES SOUTH-EAST

this organization of National Socialism abroad and the communist parties all over the world, that the legal operations of communist parties have been absolutely forbidden in a large number of states and the illegal operations of communist parties and groups have in practice been reduced to a minimum by administrative measures ; on the other hand, National Socialist operations have been officially outlawed only in a very few countries, such as Russia, Austria, Poland, and Czechoslovakia, and in these countries, too, illegal operations, even if only with regard to the German Minorities, which are always used as the advance guard of the National Socialist Organization Abroad, are very lively in spite of police and other measures.

It can be shown that even today the National Socialist Organization Abroad, founded in 1937 under the leadership of Gauleiter Ernst Wilhelm Bohle, is an organization which literally spans the world, which not only has groups and offices in all parts of the world (almost exclusively legal), but also interferes in the internal politics, especially of the South-East European states, in a manner which was entirely unknown in international relations before National Socialism's seizure of power in Germany.

The main characteristic of this organization, frequently called the "Nazintern", the international importance and extent of which was never even approximately attained by the Third International, even at the zenith of its power, is the fact that it is by no means limited to subjects of the German state. Its supreme leader, Bohle, who was born in Bradford, is a British subject. He has not only actually got a British passport, but also is in charge of millions of people who are neither themselves German subjects nor can even 


\section{GERMANY PUSHES SOUTH-EAST}

prove descent from parents who were subjects of the German Reich.

In addition it is remarkable that this Nazintern is in charge not only of the Germans abroad and those members of the so-called German racial entity who are not subjects of the German state, but also of numerous organizations which pursue purely the nationalist interests of their own races, but of their own free will submit to the National Socialist Organization Abroad because the aims of their internal and foreign policy and their struggle with their own compatriots of other philosophies are best and most amply subventioned and supported in every way by this Nazintern.

In contrast to the Communist International, which at least de lege was always kept separate from the Russian Government, until it finally really continued to exist in name only the Berlin Government not only admits its official co-operation with the National Socialist Organization Abroad, but expressly describes it as an instrument of the National Socialist Party, which, as is declared again and again, is identical with the Third Reich.

By an order dated January 3oth, 1937, nominating E. W. Bohle chief of this "Foreign Organization attached to the Foreign Office", all attempts occasionally made to admit at most only a certain co-operation, but not the official operation of this organization as an organ of the German Government, are abandoned. Speaking of the head of this organization in this order dated January 3 oth, I937, it is said that he "is entrusted with the conduct and management of all matters concerning subjects of the Reich living abroad falling within the competence of the Foreign Office". This official capacity is shown particularly by the fact that 
the chief of the National Socialist Organization Abroad is to take part in Cabinet meetings. In other words, this is a special department of the Berlin Foreign Office, which can dispose in all its activities outside of the Reich frontiers of the entire official apparatus of the German foreign political service, and particularly the diplomatic service, etc., in every respect.

At this point the stand might be taken that this concerns only transactions with the German subjects domiciled abroad. Even this would be an important encroachment upon the rights of the states concerned, for in international commerce it is universally recognized that only the official diplomatic and consular representatives can exercise such functions for certain specific, sharply delineated purposes ; this is, however, not the function of a party organization whose purpose it is at the same time to pursue propagandist aims in the sphere of the internal politics of those states in which citizens of the German Reich are domiciled, in other words more or less all over the world.

If it is considered that not only do just these Central and South-East European states grant their hospitality to a relatively very large number of "genuine" Germans abroad, but also that in nearly all of them large selfcontained German Minorities live who are not subjects of the Third Reich, it will be seen that in practice the Berlin Foreign Office and the N.S.D.A.P., through the intermediary of this thoroughly internationally developed organization, enjoy the possibility of continual interference in the politics of the Central and SouthEast European states. That it also does exploit these possibilities to further the policy of the National Socialist Party has been proved in innumerable cases, 
for the ties between the organization of the numerous cultural, sporting, musical, and other societies of the German Minorities in the Central and South-East European countries and the state and party authorities in Berlin, which are identical, are exceptionally close, and find expression, for example, in frequent journeys made by the leaders of these Minority organizations to Berlin, Stuttgart, etc.

The activities of this National Socialist Organization Abroad are, however, by no means confined to covering "all people of German tongue and Aryan origin" (who are described as "German compatriots" without regard to their nationality) as laid down in the party statutes.

The third task allotted to this Foreign Organization can be considered as limited to the sphere of foreign politics, and consists in the furtherance of all endeavours parallel to a revision of the frontiers in Central and South-East Europe in the interests of the Third Reich and its allies. The intervention in the internal politics of the Central and South-East European states thus becomes a more and more dangerous weapon in the hands of the Third Reich's foreign policy, especially where normal diplomatic methods fail.

In spite of all Berlin's efforts, its purely foreign political endeavours and its economic propaganda (both of which have been analysed here already) have been able to attain only limited success. This interference in the internal politics of the states in question, on the pattern of the example experienced in Spain in 1936 and 1937, has become perhaps the most important method of furthering the German thrust south-castwards along the line Berlin-Baghdad, 
GERMAN PUSHES SOUTH-EAST

which, as has already been explained, is to drive a wedge into the land route connecting Great Britain with the heart of the Empire.

This policy of intervention can be divided into three phases, which shall now be analysed. First, naturally, the influence over the German Minorities in the SouthEast (justified by cultural and other considerations) which almost everywhere, after they have been won over by National Socialist propaganda, become the advance post of the German thrust south-eastwards. Secondly comes the utilization of the non-German, anti-democratic, and fascist groups, most of which work with weapons of terror for a strengthening of the influence on internal politics enjoyed by parties and persons amicably disposed to Germany. Thirdly and lastly, the growing successes in the sphere of foreign policy will be investigated, which, together with the methods of the normal foreign policy and the National Socialist economic propaganda, further Germany's push South-East in the spirit of the all-German ideology adopted even under Wilhelm II-in a way which constitutes the most serious danger for European peace. 


\section{Chapter $X V$}

THE "VOLK OHNE RAUM" AND THE GERMAN BROTHERS IN THE SOUTH-EAST

THE programme of the National Socialist Party, the immutability of which is expressed in the concluding sentence :

The party leaders promise to strive for the accomplishment of the preceding points, where necessary, at the risk of their own lives, without consideration for any other interests,

is headed by a claim which quite unmistakably shows the endeavour of the National Socialist régime to reach out over its boundaries, letting neither treaties nor any kind of "gentlemen's agreements" divert it from the claim advanced to all Germans living anywhere in the world, that is, even outside the boundaries of the Reich. Point I of the National Socialist Party programme reads :

We claim the union of all Germans in one Greater Germany, on the basis of the nations' right to self-determination.

It is true that the many changes and chances of history in Central and South-East Europe and the mixed national character of the old Habsburg Empire have led to the creation and maintenance of large 180 
German settlements in this part of the Continent, but it would be quite a mistake to assume that the Germans scattered over the various states in Central and South-East Europe represent an alien clement in these lands.

The typical example is Bohemia, where Czechs and Germans have lived intermixed for more than a thousand years and at heart have always been conscious to what a considerable extent they are mutually interdependent. Many hundreds of thousands of Czechs live in the Sudetic German districts on the Czechoslovak borders, and in the districts predominantly inhabited by Czcchs, again, there are hundreds of thousands of German families; in this connection it is interesting to note that there is an exceptionally large percentage of Czech names among the Sudetic Germans and of German names among the Czechs.

Here, as in nearly all countries in Central and South-East Europe, history has led to a considerable interbreeding between the Germans, Slavs, and Romanic races, and there is hardly anything more senseless than to apply the principle of a right to selfdetermination-which in itself is just-to those parts of Central and South-East Europe the peoples of which for centuries past have shown a high degree of interbreeding.

Such a claim can least of all be realized according to the racial principle advanced by National Socialism, and the Third Reich's policy towards its own Minorities (Poles, Wends, Jews, etc.) shows clearly how lightly National Socialism takes the impracticable demand to a right over all Germans for itself, or rather for a "Greater Germany", and on the other hand rejects I 81 
all those who according to the well-known racial principles are not admitted to be pure-blooded Germans. These impracticable demands are, accordingly, formulated without any reciprocity; in this connection we must bear in mind Point 8 of the National Socialist programme, which lays down that "all further immigration of non-Germans is to be prevented".

The real aim of these "Greater Germany" claims, which, by the way, are strongly reminiscent of the pan-German dreams of the creation of a mighty colonial empire on the line Berlin-Baghdad (which we have already discussed), is, moreover, naturally not the incorporation of German people, but rather the acquisition of all the territories inhabited to any considerable extent by Germans. The thesis advanced by National Socialism, that present-day Germany is a "Volk ohne Raum" ("nation without space"), is intended to be complemented by this claim for the incorporation of all territories to any extent inhabited by Germans. Under the cover of the slogan of a liberation of the German brothers in the South-East, the attempt is made-to a still higher degree than during the all-German period-to promote the idea of a gigantic expansion of the Third Reich, an expansion which would not be limited even by the line Berlin-Baghdad, but which would also reach northwards to the fertile plains of Southern Russia and particularly the Ukraine.

And how does it stand with the statement that Germany is inhabited by a "nation without space"? Vast areas of the Third Reich are in point of fact as good as unpopulated, and a glance at the distribution of land in the German statistical annuals is sufficient 
GERMANT PUSHES SOUTH-EAST

to show what large areas, particularly in the Eastern part of the country, have remained permanently in the hands of a small class of large landed proprietors, whose power has done more since 1933 than ever before to prevent an even approximately sound distribution of the land among the German population. A collection of studies published by Sehring in 1932 under the title Die deutsche Landwirtschaft unter volksund weltwirtschaftlichen Gesichtspunkten shows that the duty and subvention policy had contributed to a considerable extent towards preventing German agriculture from participating in the favourable international development, and that the naturally unproductive large estates in the East, which are mostly extensively exploited and grow corn and fodder, were maintained at the cost of the peasant holdings.

After National Socialism's seizure of power this development was by no means arrested, but actually accelerated, and all attempts to achieve a more suitable distribution of the land by effective settlement and land reform such as was successfully carried out in many Central and South-East European countries, for example, Czechoslovakia and Roumania, by doing away with the latifundia system, failed again and again in the face of the powerful position and the opposition of the large landed proprietors in East Germany.

However widely divergent the opinions of scientific agricultural authorities may be in other respects, they almost all agree that the abstention from land reform and a wrong distribution of the land is the cause of the overpopulation of certain parts of Germany. In other words, there can in reality be no question of a "Volk ohne Raum"; on the contrary the maintenance 
of the privileged position of a class of large landed proprietors in Eastern Germany has always contributed towards making vast areas of Germany a "space without people".

According to official German statistics published after National Socialism's rise to power there are about 140 inhabitants per square kilometre. In comparison with other highly industrialized European countries this figure is by no means high ; for England and Wales the corresponding figure is over 264 , for Belgium 265, and even for Czechoslovakia, which is much less highly industrialized, about 105. For Holland, whose agricultural population is very high, although the distribution of land, it is true, is much better, the figure is actually $23^{2}$ inhabitants per square kilometre.

The thesis of a "nation without space" is therefore, on the one hand, calculated to maintain the privileged position of East German landed property, which from an unbiased economic angle is inefficient, and, on the other hand, to procure an apparent justification for the German efforts at expansion, which under National Socialism have been directed mainly southeastwards.

The counterpart to the slogan "Volk ohne Raum" is that of the "liberation of the German brothers". The moral justification put before the world for this idea of liberation is always that the Germans living beyond the boundaries of the Reich in Central and South-East Europe, whose very considerable interbreeding with Slav and Romanic elements is left unheeded, can be said to be languishing under foreign rule. What are the historical facts? The Germans of Bohemia, for example, have never belonged to I 84 
Germany proper. Their culture, their history, their whole style of life have been determined by the development of the Habsburg monarchy and the long period of their life among the Czechs in a common homeland, and a forcible severance of the bonds created by history would be contrary to all political common sense.

This applies to at least the same extent to the Volga Germans, the Transylvanian Saxons, and the Germanspeaking settlements in Yugoslavia, Bulgaria, Hungary, and so on. The idea of liberation and the totalitarian principle expressed in the first point on the National Socialist Party programme, which normally would not stop at the Germans in the Southern Tyrol, AlsaceLorraine, Poland, and the South of Denmark if purely political and strategic considerations did not make it appear desirable to adapt the National Socialist policy in each of these cases, reveal themselves as the rebirth of the German attempts at expansion which in the form of "All-Germany" led to the outbreak of the Great War.

It is now important to observe how the propaganda of the idea of liberation and of the totalitarian principle in the South-East is always utilized for purely political purposes. According to international agreements and Minority treaties Germany has no title to pose as a protector of the Minorities in other states; it is a matter purely for the League of Nations and the Permanent International Court at The Hague to watch over the guarantees regarding Minorities. In March I 936 the Czechoslovak Minister for Foreign Affairs, Dr. Krofta, referring to Article 86 of the Treaty of Versailles, rightly declared that the point in question "gives Germany no obligations at all and 185 
no rights even if we disregard the fact that Germany is no longer a member of the League of Nations and that on principle it does not recognize the stipulations of the Treaty of Versailles.

Nevertheless, however, the entire German southeastern policy, after National Socialism's seizure of power, has been directed towards organizing the "unliberated Germans", making them into an instrument of Germany's foreign policy in the internal politics of those states whose citizens they are, thus strengthening Berlin's influence on the politics and economics of the Central and South-East European states; this is one of the most important characteristics of the German push South-East. Attempts are made to weaken the power of the governments in the states concerned, and in this way to obtain influence to which, according to the generally accepted principles of international law, the Third Reich is not entitled.

The organizatory connections between the political parties of the German Minorities in the Gentral and South-East European states have been elucidated on more than one occasion.

It is characteristic to note that the same National Socialism, which with regard to Russia, for instance, poses as the protector of the idea of sovereignty and again and again emphasizes how grave a danger for European peace lies in the fact of one state interfering with the internal conditions of another by the use of ideological means, pursues the very policy with which Russia and other members of the League of Nations are reproached, although they have proved more than once that, in the interest of world peace, they strictly follow the principle of non-intervention 186 
even when in practice this principle is not observed by others.

A fully satisfactory solution of all the Minority questions in Europe is probably entirely impossible, and continual changes in the frontiers would of necessity automatically create wrongs probably considerably greater than those which, whenever necessary in the interests of Germany's efforts at expansion, National Socialism points out in the neighbouring countries, particularly in Central and South-East Europe. In practice the sole consideration is as complete as possible a protection of the Minorities from encroachment of any kind upon their rights.

Even though many mistakes may have been made, the members of the League of Nations have repeatedly given proof of their good will to regulate their Minority problems in as fair a manner as possible. The financing and organization of "movements", which themselves do not recognize the principle of democracy, but are intended to facilitate the advance south-eastwards in the interest of Germany's foreign policy, cannot in the slightest contribute towards speeding up as just as possible a solution of the nationality problems in this part of Europe.

The aim of the development of National Socialist organizations among the German minorities in the Central and South-East European states is not to serve international peace, but rather to create and accentuate the tension; it is just this tension which the Third Reich needs in order to create an atmosphere of general insecurity, which in turn must lead to an international conflagration. This, of course, is not intended to convey the idea that the minority problem, which exists not only here but also in other parts of 
GERMANT PUSHES SOUTH-EAST the Continent and the rest of the world, can be considered definitely settled. On the contrary, for the sake of an international pacification it is necessary that each government which professes the idea of collective security continue to strive for as just a solution as possible. The National Socialist policy of exploiting the German Minorities in the interest of the realization of its expansion thrust can but hem such a development and do nothing but harm to the Minorities themselves. 


\section{Chapter XVI}

HOW ARE THE GERMANS ABROAD PROTECTED?

IN practice, the protection of German Minorities outside the Third Reich by National Socialism is manipulated in a manner entirely at variance with programmatic declarations. While in theory and for the purposes of propaganda it is maintained, and expressly stated in the first paragraph of the party programme, that a union of all Germans in a Greater Germany is to be striven for, in point of fact it can be seen that, in order to further the German push SouthEast, in other words purely from the angle of foreign policy, a sharp distinction is drawn between the Minorities in the states with which alliances have been concluded, such as Italy, Poland, Hungary, etc., and the German-speaking Minorities in the Baltic, the countries of the Little Entente, Alsace-Lorraine, etc.

Quite apart from the question of the true value to be attached to the bilateral treaty concluded between Belgrade and Rome in March 1937, this treaty shows that, after all, Yugoslavia made considerable sacrifices in order to obtain cultural and political alleviations for the Croat and Slav Minorities domiciled on Italian territory. The entire history of the German-Italian relations after the seizure of power in Berlin by a system so similar to the Italian form of government does not show the slightest signs of German protection of the interests of the Germans living in Northern Italy or of the exertion of even the slightest influence in 
order to achieve some small improvement of their situation, at least, in the sphere of culture.

Although German statesmen very frequently went to Rome for political discussions, and that at a period in which no journey of the members of the Yugoslav Government to Italy took place, none of these opportunities was utilized to the endeavour, for example, that Germans in Southern Tyrol be taught in the German language, that their church services be held in German, or that they even be permitted to put inscriptions in German on the tombstones of their dead. If, as is so often officially emphasized, the principle of nationality is the sole consideration governing the Third Reich's entire Minority policy, it remains unexplained why this principle of nationalism is so completely ignored just in the case of Italy.

This situation is quite similar to that of the very large German Minority in Poland since the year I934, at the beginning of which the National Socialist government of Berlin concluded a pact of friendship with Warsaw. The Berlin Government, otherwise so active in matters concerning the Germans abroad, suffered the paltry rights conferred upon this German Minority under the former democratic régime in Poland to be cancelled without the slightest protest. In Poland one German school after another was closed without this matter being taken up by German quarters on the occasion of the numerous visits paid by German statesmen to Warsaw and to the Polish shootinggrounds, when so many points were discussed.

On the other hand, the Third Reich's inland Press was more than once instructed not to publish letters of protest from members of the German Minority in Poland, and to avoid any debate about these questions 


\section{GERMANR PUSHES SOUTH-EAST}

in the columns of German newspapers, and especially in the periodicals which concern themselves with the Germans abroad. The situation of the Germans in Hungary is quite similar. As is well known, the Hungarian Prime Minister Gömbös advocated most decidedly the establishment of a National Socialist régime in Hungary. He undertook many journeys to Germany, and even died in Munich in 1936 without having previously resigned his office, although he could hardly perform it from Germany in the manner usually recognized for the activities of the head of a government.

Germany, which, moreover, strengthened its economic relations with Hungary to an extraordinarily great extent, never once used the opportunities which frequently offered themselves to discuss the interests of the German Minority in Hungary. Stuttgart has been given the name of "a town of the Germans abroad", and the institution operating there, the "Association for the Support of Germandom Abroad", which is constantly subventioned by the Berlin Government with large sums, develops very extensive activities. It would, however, be a mistake to assume that these activities include the entire German population domiciled outside the borders of the Reich. Its chief task is rather the propagation of fascist ideas and the exploitation of certain special Minority questions in the interest of the foreign policy adopted particularly towards those states in Central and South-East Europe in whose political, moral, and military weakening Germany is interested.

If we select from the numerous other examples of German propaganda for the Minorities the Henlein movement in Czechoslovakia, we find that the position 


\section{GERMANT PUSHES SOUTH-EAST}

of the Sudetic Germans has only been weakened by the organization of this fascist movement from Berlin, and that it was just the parties entirely independent of Berlin, the so-called "activists", represented in the Czechoslovak Government by three Cabinet ministers, that by the reconciliation between Czechs and Germans, which was concluded by an agreement signed in February 1937, have improved the situation of the German Minority in Czechoslovakia to such a considcrable extent that today it is in spite and not because of the attacks of the Henlein movement on the democratic constitution of this country that the Germans in Czechoslovakia live as "equals among equals", which is far more than the obligations assumed under international agreements call for, and which, too, is in harmony with the principles of democracy.

The tactics adopted by National Socialism in Czechoslovakia with the help of the Sudetendeutsche Partei (Sudetic German Party), under the leadership of Konrad Henlein, may be considered typical of its methods of undermining democracy in the Central and South-East European countries. Konrad Henlein, who wishes to be more or less Hitler's deputy for Czechoslovakia, and is considered as such in Berlin and Stuttgart, the seat of the "Institut für das Auslandsdeutschtum", claims primarily self-rule for the Sudetic Germans. According to a bill of his submitted to Parliament by the Deputies of his party in 1937, all the German districts in Czechoslovakia, regardless of their geographical continuity, should be constituted a separate entity.

According to this proposal, the supreme organ of organization and really of government in this territory 
would be a committee chosen from the German members of the Prague Parliament, of whom Henlein's adherents form a majority of about $66 \%$. At the head of this organ there would be a "leader", to whom, for reasons of expediency, the title of "speaker" was given. Among the functions of this speaker would be that of representing abroad the German-speaking citizens of Cizechoslovakia.

The "leader of the Germans", Henlein, was not only given the honorary degree of doctor at Stuttgart, but was also made honorary president of the Institute of Germans Abroad, which holds the most important threads of National Socialist propaganda in the South-East. In the autumn of 1937 , immediately after Mussolini's visit to Berlin, Konrad Henlein declared that his party is now "the third largest anti-Bolshevist party in Europe". There is hardly one of the innumerable National Socialist newspapers in Austria, Roumania, Hungary, Bulgaria, etc., that does not draw its most important news material from the central organ of the Henlein party, Die Zeit. The connection with the illegal Austrian National Socialist groups, which are united under a similar "deputy for Hitler" in Austria, Captain Leopold, is particularly close.

In July r937 Heinz Rutha, the delegate of the Henlein party to the London Minority Conference, said: "I warn all Europe of the catastrophe which is threatening. If the natural causes of the conflict are not removed, the motherland will remove them-it protects its brothers in the Minority districts."

The main task of the Henlein party is naturally its endeavour to change the direction of Czechoslovakia's foreign policy, i.e. to induce Prague to abandon the principle of collective security and above all its 
treaties with France, Russia, and the Little Entente state, and to substitute reliance in the powers of the Berlin-Rome axis for Prague's present foreign policy.

Members of the Henlein party, and politicians who stood at least exceptionally close to it, have in numerous instances saved themselves by flight over the boundary of the Third Reich from prosecution for political and criminal misdoings. Very like the Austrian National Socialists who fled to Germany, they in many instances were given high honorary positions in the National Socialist Party and even became high state officials.

It has been proved in many cases that the German frontier authorities have accepted a card of membership of the Henlein party as fully equivalent to a passport for the purpose of crossing the frontier. The constant subvention of the party by National Socialist quarters has been frequently demonstrated by documents, particularly by the publication of documents issued by German banks, and in numerous cases of this kind the Henlein party either abstained from attempting to prove the falsity of such allegations before the competent courts of justice, or, contrary to the allegations of the Henlein party, legal proof of the authenticity of individual documents was brought. In a large number of cases the Henlein party, at mass meetings and in Parliament, repeatedly advocated a close alliance between Czechoslovakia and Germany, which, as Henlein himself said in a speech on October 17 th, I937, "is at present once more honoured and loved by many". The Czechoslovak German Minority problem itself, like every national Minority problem, presents certain difficulties, and both sides have admitted that certain mistakes have been made; 


\section{GERMANY PUSHES SOUTH-EAST}

the attempt is now being made, in an atmospherc of mutual goodwill, to make these good.

For the Henlein party, led and financed as it is by German National Socialism, the object is not an unbiased solution of the problem of the co-operation and friendly relations of the 3,250,000 Germans in Czechoslovakia with the majority nation, but merely support for German National Socialism's efforts at pan-German expansion south-eastwards. The Henlein party, more than almost any other fascist German group in the countries of Central and South-East Europe, may be considered as the perfect instrument of the German thrust south-eastward.

Examples of this kind can be found in any number. Recapitulating, we may say that paragraph I of the National Socialist programme, for the accomplishment of which the party leaders promised "to strive, where necessary, at the risk of their own lives, without consideration for any other interests", applies only where it suits the interests of National Socialism's foreign policy.* Consequently there can be no question of a genuine national claim, but rather of an exploitation of the Minorities to further the German "Drang nach Südosten" and to spread fascist ideas in those states of Central and South-East Europe which to the best of their ability have put themselves on guard against the totalitarian principle and have maintained the principles of democracy. The actual aim of the demand for unconditional protection of all German Minoritics

* Characteristic was, to give a Roumanian example, the statement of Hans Roth, the leader of the "Movement for a National Revival of the Germans in Roumania", who, speaking in the Roumanian Parliament, said plainly:

"The Government should notice that the German Minority is not so much a racial group as a bridge to a great nation." 
abroad is revealed equally clearly by the fact that so national a régime entertains close connections with all parties and movements in the Central and South-East European states which seek to help fascist tendencies to victory over democracy.

It can be seen in almost every country in Central and South-East Europe, and particularly in those whose German Minorities have continually appealed in vain to Berlin for political and moral support, with what sympathies the national groups and parties of the ruling nations are greeted and financially supported, although these groups, in addition to the Jews - their programme is almost without exception highly antiSemitic-attack the Germans who have lived for centuries in the states in question and who really have often rendered valuable services.

As will be shown in the next chapter with the aid of concrete material, these sympathies and relations with the fascist and in most cases decidedly anti-German organizations are admitted openly, and prove with an incontestable lucidity that the entire principle of the protection of the Germans abroad, so frequently emphasized from propagandist motives, is in practice merely a propagation of anti-democratic ideas in order to further the aims of Berlin's foreign policy. Since the seizure of power by the National Socialist Party in Germany, the so-called "protection of the Germans abroad" has become an instrument of the conversion of Central and South-East Europe to fascism, an aid to the German push South-East, and thus an instrument of inestimable importance for the maintenance of continual unrest in this part of the Continent and for threatening the peace of Europe in general. 


\section{Chapter XVII}

THE "DRANG NAGH DEM SÜDOSTEN" IN ALLIANGE WITH THE NON-GERMAN FASCIST ORGANIZATIONS

Since 1933 the interest of German foreign politicians has been devoted more and more to the numerous fascist groups abroad, irrespective of the question whether or not their programme and practice claimed a co-ordination of their countries' foreign policy to that of Germany. Adherents of an approximation to Italian Fascism have, it is true, been frequently disappointed, and the German literature dealing with it and with the numerous guild-groups in Austria, which ideologically are closely connected with Italian Fascism, declares often enough that there exists an essential difference between Italian and German Fascism.

If we examine the reason for this we find that the contrast lies mainly in the fact that Italian Fascism, even in its Austrian, Bulgarian, and other varieties, refuses to accept anti-Semitism as a conditio sine qua non, while German National Socialism and the movements closely allied to it, particularly in the South-East, nearly all declare that National Socialism is unthinkable without an unconditional combating of Judaism. In addition, there is the repudiation and combating of the Catholic Church, the Christian religion, and the Bible, which are characteristic of National Socialism. This repudiation of Christianity and its substitution by numerous forms of religion which, it is true, take the 


\section{GERMANY PUSHES SOUTH-EAST}

name of the Christian religion but sharply reject the true spirit of the Bible, are ideologically justified by National Socialism on the grounds that true biblical Christianity is inseparably bound up with the Jewish race and its intellectual outlook, which must be combated.

A more comprehensible reason for the anti-Christian and particularly anti-Catholic attitude of National Socialism, which is not shared by Italian Fascism, can be found in the sphere of politics: the fact that National Socialism refuses to admit any form of international intellectual power. The National Socialists formulate this in a sentence which clearly indicates the emphasis on race, viz. on the German race, as a part of the antithesis between it and Italian Fascism. Werner Haas opens his very illuminating book Europa will leben (Europe Wants to Live), which contains invaluable material regarding the numerous fascist organizations in nearly all the countries of Europe,* with the remark :

Exclusivity is an essential part of National Socialism; in other words, it wishes to embrace only its own fellowworkers and compatriots and lead them to a racially pure isolation and a level true to the character of their race. It therefore excludes elements foreign to the race and species, and refuses to acquire and to assimilate such elements.

This sentence is ideologically remarkable for the comprehension of the distinction between the German and the Italian Fascism, and it is doubly interesting in this documentary work, the purpose of which is to

* It is interesting to note that this voluminous work does not deal with Czechoslovakia and Austria, because, for political reasons, it is considered undesirable for any connection between the Henlein movement or the Austrian National Socialism and the German régime to become evident. 


\section{GERMANT PUSHES SOUTH-EAST}

show what extraordinary interest and what a pronounced initiative National Socialism devotes to thc growth of fascist, anti-parliamentarian, and antidemocratic movements of all kinds in all the countries in Europe, particularly in the South-East. The aims of these movements are in all cases to obtain the unconditional and supreme rule of the (non-German) race in question over all nations, such as, for example, the German Minorities, which live in the countries concerned. If National Socialism were really concerned only with members of its own race and nation it would of necessity have to combat all endeavours of fascism abroad, such as, for example, the Mosley group in Great Britain, the "Groix de Feu" in France, the Arrow Cross in Hungary, the Iron Guard in Roumania, the Zankoff movement in Bulgaria, and so on.

In point of fact, however, there can be no question of this, and the strengthening of these fascist organizations, which co-operate very closely with Berlin, is celebrated as a great success. The reason for this apparent contradiction lies in the fact that, in their several countries, all these fascist organizations claim an approximation to National Socialist Germany's foreign policy and a change in the orientation of their countries' foreign policy away from the democratic states in the West, that is particularly France, Great Britain, the U.S.A., etc. The demand thus formulated is hardly ever based on unbiased considerations of expediency from the point of view of foreign policy, and is merely an expression of sympathy with similar ideologies represented in Berlin and Rome. Furthermore, as must be openly stated, it is the result of the influence and material support given by Berlin, which hopes that by strengthening these organizations the 
countries will be alienated from the democratic states' system of alliances, regardless of whether or not this is in the real interest of the countries in question.

In the book in question the push South-East is clearly documented by a description of the origin, programmes, leaders, the Press, etc., of the fascist organizations in the Central and South-East European states (with the two exceptions already mentioned), and we find in it comprehensive material regarding Berlin's influence on the development of the internal politics of the South-East European states concerned.* Thus, for instance, in Roumania we find three fascist parties, which have in part adopted both the swastika as emblem and the Hitler greeting, and all agreeing that everything should be done to change the orientation of Roumania's foreign policy by an estrangement from the Little Entente and its western allies, and to ensure as close an approximation of Roumania to the BerlinRome axis as possible.

The first of these is the "Liga Aparrării Nationale Crestine" (League of Christian National Defence), founded by Professor Cuza. The education of this professor-now about eighty years old-at an intermediate school in Dresden and at the German Universities is always emphasized.

This League gives a prominent place in its programme to anti-Semitism and demands complete expulsion of the Jews from public life, a numerus clausus for commerce, industry, and the liberal professions, as well as a numerus nullus for all Minorities in any public offices and in the army. Even

* Werner Haas : Europa will leben. Die nationalen Erneuerungsbewegungen in Wort und Bild. Batschari-Verlag G.m.b.H., Berlin, IV.57. 
GERMANY PUSHES SOUTH-EAST from this programme of the least radical of the Roumanian Fascist movements, it is absolutely clear that not only the Jews, but also all Germans, are to be expelled from public office and the army.

Characteristic of this League is, further, as regards foreign policy, its hostile attitude to Roumania's "francophile" course, and the demand for a close rapprochement to Germany. The struggle against Titulescu, who is rightly regarded as the typical advocate of the idea of the Little Entente and of Roumania's orientation towards the West, determines this party's attitude in internal politics just as much as does its decided rejection-in the very spirit of the National Socialist programme-not only of communism, and all socialist and democratic tendencies, but also, most emphatically, of any rapprochement with the Russian neighbour in the field of foreign policy. Judaism and Bolshevism are put on an equal level in the League's programme-almost word for word as is done in Hitler's writings--the League having, in 1935, joined forces with Octavian Goga's National Farmers' Party, forming under the new name "Partidulni National-Crestin" (National Christian Party) a regular political party, whose honorary president is Professor Cuza, with the farmers' leader Goga as the real leader of the party.

The most important points on the party programme were proclaimed by Goga in 1935 in the Roumanian Parliament; we find there, in addition to a pronounced nationalism and anti-Semitism, the slogan of the combating of Freemasonry and "liberalist democracy", while at the same time an unconditional avowal of loyalty to the monarchy is made. The election slogan is announced as "Roumania for the 


\section{GERMANT PUSHES SOUTH-EAST}

Roumanians!' The original Cuza programme was here already outdone and the Roumanian principle of nationality claimed (in other words, a numerus nullus for all Minorities, such as Jews, Germans, Hungarians, and so on) for the army, finance, administration, the teaching profession, all state authorities and undertakings. Further, in almost exact conformity with the National Socialist programme, claims are made for the abolition of all trusts and cartels, as wcll as all unjustified laws for the protection of industry. And the claim for the control of all naturalization papers issued after the War, well known from the German National Socialist programme, is not absent, nor that for the "purging of the Press from foreign intruders". The official organ of the Roumanian National Christian Party is the newspaper Tara Noastra (Our Country).

Although the party programme is here almost completely adapted to that of German National Socialism and in practice represents a-for Berlin naturally very welcome-Gleichschaltung (unification) of the Roumanian internal and foreign policy with that of the Third Reich, the party continues to co-operate in the government of the country. The principle of the abolition of Parliament and the achievement of all political demands by methods of terror is still more pronouncedly held by the Iron Guard ("Garda de Fier").

In spite of its nominal dissolution, the Iron Guard has not disappeared from the political life of Roumania. It continues to play an important part in Roumanian public affairs under the sign of the swastika and with a new name ("Totul pentru Tara", that is, "Everything for Our Country"); not until the beginning of the year 1937 did the Tatarescu goverument takc up the 
struggle seriously with the Iron Guard, which, though forbidden, in reality continues to exist.

The founder of the Guard was Corneliu Zelea Codreanu, who, leaving the Cuza party, founded the Iron Guard as an independent organization in $193 \mathrm{I}$. Here, too, of course, anti-Semitism on the German pattern takes first place in the programme; at the same time, however, a dictatorship is openly claimed as the most important political aim, with a still more pronounced nationalism than was advocated by the Cuza party, if this is at all possible.

In the case of the Iron Guard, it is interesting that its programme openly claims "training for youth on the German pattern, expulsion of the western democracy of French origin, revolt against the servitude of indebtedness, abolition of all political parties", etc., and it is hardly necessary to point out that this is actually a literal repetition of the most important points of Adolf Hitler's German National Socialist Party. The declaration of the principle of leadership is naturally not lacking, and the five rules which must be sworn to by each member under threat of terrorist punishments include in particular reticence, fanatical labour for the liberation of the soil from the rule of super-state powers, blind obedience, and so on.

The adherents of the Iron Guard, who continually proclaim that they march under the swastika, include not only students and officers, but also peasants and priests. In the trial instituted after the murder of the Premier Duca by the Iron Guard, three members were condemned to penal servitude for life, but at the same time all the other accused were acquitted, including Codreanu, the leader of the Iron Guard.

From the data here furnished from German sources 203 
it is difficult to believe that a closer connection between a fascist group and German National Socialism is possible. This is, however, the case, for at the beginning of 1933, under the leadership of a retired colonel, Stefan Tatarescu (not to be confused with the Roumanian Premier), a third organization, the socalled "Steel Shield", was founded, which had formerly borne the name "Roumanian National Socialist Party". This has a programme of twenty points which, in the words of the German work already quoted, "in its essential aims is in harmony with German National Socialism".

Here, too, we find the swastika as symbol. The periodical of the "Steel Shield" bears the name "National-Socialistul" (The National Socialist). Officially two thousand members are reported, but in point of fact the number is probably considerably higher. However, the Reich's influence on the two other, far more important, parties is so unequivocal, and strong that the "Steel Shield" is probably only a sort of alibi, particularly because this movement demands correct treatment for the loyal German subjects. This claim is very unpopular among the Roumanian radicals of the Right, and for this reason the centre of gravity of the German influence on Roumanian internal politics has been transferred to the two first-named parties, which represent Roumanian nationalism in a more pronounced and consequently more popular form.

From these facts it will be sufficiently clear to what a considerable extent German National Socialism, which is supposed to be just as little suitable for export as Italian Fascism, adapts its tactics in a SouthEast European country exclusively to the furtherance 204 
of foreign policy and of the push South-East, renouncing every jot of national German sentiment and the protection of the German Minority.

Not only in the anti-revisionist countries, however, which National Socialist Germany wishes to bring into its wake through influence exerted on their internal politics, but also in the revisionist states of the South-East, can the endeavour to adopt similar methods be traced. In countries like Hungary and Bulgaria, for example, the aim is to hinder all attempts at democratizing the internal politics, which might possibly lead, among other things, to an improvement of political relations with the democratic states and to an abandonment of the axis Berlin-Rome; this is done by the creation of more or less terrorist groups and the support of similar organizations, in order to maintain pressure on the foreign policy of the governments in question.

In Hungary the Hungarian National Socialist Party ("Magyar Nemzeti Szocialista Part") was founded by Zsoltan Böszörmény at the beginning of 1932, also under the sign of the swastika; the propaganda for this party was made predominantly by student circles. Later there were amalgamations with similar organizations and schisms, so that finally there were three National Socialist parties. They subsequently, in June 1934, united under the leadership of Count Festetics to form the new "Hungarian National Socialist Party", which later absorbed numerous other groups.

On the German pattern, storm troops were founded, and when, at the end of r 934, the further use of the swastika was forbidden, it was replaced by the so-called "Arrow Cross". After the dissolution of the storm 


\section{GERMANT PUSHES SOUTH-EAST}

troops by the authorities at the end of I934, and after the prohibition of the party paper, the party was reduced to personal recruiting. According to its programme, the party demanded the restoration of the thousand-year-old Greater Hungary, and the revision of the Treaty of Versailles, and in the racial question followed almost slavishly the example of German National Socialism. In Article 6 of the programme, which comprises twenty-six points in all, we read :

He only can be a fully qualified citizen who can prove his Aryan descent to as complete an extent as possible and whose patriotism has never been in doubt.

This is supplemented by the claim made in point 9 for

the prompt deportation of all not fully qualified citizens who came into the country after 1880 .

The further demands include the abolition of the existing parliamentary system, which is based on party rule, the immediate dissolution of all cartels and liberation from the servitude of indebtedness; the last point on the programme is a demand for the precedence of the interests of the nation over those of the individual in all spheres of daily life, which is almost a literal repetition of the National Socialist principle "Gemeinnutz geht vor Eigennutz" (the weal of the State comes before that of the individual). The members of the Arrow Cross organization wear the green shirt and have adopted the Hitler greeting. During the parliamentary elections in April 1935 they gained I 70,000 votes; the following not uninteresting cxplanation was given in the Reich for this not very satisfactory result : 


\section{GERMANT PUSHES SOUTH-EAST}

In connection with this voting result it should be borne in mind that on the one hand a considerable percentage of the party members has not yet reached the age necessary for the acquisition of a vote, and on the other hand in Hungary there is an open and not a secret ballot.

After the death of Gömbös, National Socialist propaganda in Hungary at first declined, and in 1937 the government, through the Minister of the Interior, Szell, stated in the Hungarian Parliament that the German, like all the other Minorities, is better treated in Hungary than in any other country. There followed a statement by Hitler's deputy that the Hungarian citizenship of the German Minority is always respected and that no attempt at all will be made to endanger the peace and security of allied Hungary. Thereupon the Hungarian Press was instructed not to mention National Socialist propaganda in any way in future. Nevertheless, however, very soon afterwards a further violent wave of this propaganda was launched; no doubt exists of Germany's support of it.

Characteristic of the organization of this propaganda is its extraordinary diffuseness, due on the one hand to the personal ambition of individual aristocrats, on the other to the endeavour to emphasize as many sources as possible of the propaganda; at one time the pure Magyar, at another time the nationalist German, frequently purely anti-Semitic, anti-French, and antidemocratic tendencies being in the foreground. The bond of union between all these organizations is the systematic endeavour to obtain as high a subvention as possible from German quarters, and in other respects, in spite of this diffuseness, to proceed more or less uniformly against all attempts to regenerate the Hungarian parliamentary system and against the 


\section{GERMANT PUSHES SOUTH-EAST}

restoration of friendly relations with the countries of the Little Entente and the democracies of the West.

A very well-informed source gives the true membership of the various Nazi organizations in October 1937 as follows :

"Move" (Hungarian Land Defence Union) about 15,500 Central Hungarian Workmen's Organization " I6,500 Festeticz Arrow Cross Party . . . . , , 32,000 Palffy Arrow Cross Party . . $\quad$. $\quad$. . $\quad, \quad$, 2,000 Deputy Balog's Arrow Cross Party .. . . " , 16,000 Böszörményi's Scythe-Cross Party .. . . " " 9,000 National Race-Protection Movement (under the leadership of the High Court Judge Vitéz Ladislaus Endre) . . . . $\quad$. . , , "National Front" Blue Cross Movement (led by Deputy Csilléry of the Catholic Christian Socialist Party) ", 5,000 "Turul" (Union of Graduated High-School Students)

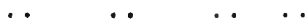

If the fact that this survey of the Hungarian National Socialists of all sorts and kinds, based on a conservative estimate, gives only the number of actual members of the organizations in question, is neglected, the total number will at first appear not to be exceptionally high. Even this total, however, amounts to well over I00,000, and the members of these organizations consist either primarily or exclusively of well-organized, militarytrained men in Budapest and the larger towns.

More important, however, is the fact that the number of partisans and adherents naturally amounts to many times that of the actual members, especially because an open campaign against the National Socialist propaganda in the Press is either not permitted by the censor at all, or only in the mildest form. Still more 208 
important, however, is perhaps the fact that these secret organizations, which have ample means at their disposal, are in very close contact with the army and police. Thus in October 1937, to quote one example only, it was found that the Arrow Cross organization took the oath of an illegal "storm troop" through the "leader", and that there is a large number of National Socialist cells not only among the state employees, but above all among the officers of the standing army.

In the case of this and similar revelations investigation by the government or the Minister of War, it is true, is generally promised, but the methods of concealment which were tried out in Germany itself before National Socialism's accession to power, which methods are readily placed at the disposal of all the secret national organizations in Central and South-East Europe, nearly always prevent the achievement of practical results by such investigation, still less the dissolution of the illegal organizations and the punishment of at least the responsible members.

The diffusion of the National Socialist organizations has resulted in the names of the "leaders" being known generally not only to the public, but also to the authorities. It is further well-known that the existence of these organizations and the work of these leaders is a most serious obstacle in the path of the endeavours of responsible Hungarian circles, which are honestly doing all they can to achieve that re-orientation towards the West of Europe and democracy which is necessary for the country and in harmony with the wishes of the great majority of Hungarians, particularly in the country districts. The close personal relations between the organizers and those members of the nation who now, as in the past, are the most powerful in the country, 
prevent the authorities again and again from giving the matter serious attention, and the prospect of the acquisition of power and riches, which appears to be guaranteed by the alliance with the Third Reich, helps the agitation launched by the inany different forms of Hungarian National Socialist organization much more than the official prohibitions, which exist only on paper, can harm the National Socialist tendencies.

Although examples of this kind can be given in any desired number for the states of Central and SouthEast Europe, it will be sufficient here to give a few details regarding Bulgaria, where on July 9th, I923, the legal government was forcibly removed and the Premier, the head of the Democratic Farmers' Party, Stambulijski, was murdered by members of the fascist organizations. Subsequently there arose various fascist organizations on the pattern of German National Socialism, but influenced from Rome, too; thus in particular the "Union of Young Nationalist Legions", of which the literature of the Reich states that its programme, though adapted to Bulgarian circumstances, in its essential points was borrowed from German National Socialism.

While the so-called Home Defence Corps ("Rodna Zaschtita") is strongly anti-Semitic and, like other organizations connected with German National Socialism, sees its chief aim in the Jewish question and withdrawal from the League of Nations, the National Fascist Union, which bears the fasces in its shield, is closer to Italian Fascism and does not concern itself with the Jewish problem.

It is characteristic that this organization, which was established on the Italian pattern, was not able to gain such considerable importance as the others, which are 
GERMANT PUSHES SOUTH-EAST

continually supported from Berlin, and in $193^{2}$ it voluntarily ceased to exist. All the more rapid was the development of the organizations founded on the pattern of National Socialism, which had a very influential Press at their disposal. The attitude of the Home Defence Corps, which was founded in 1923, to the Jewish question is expressed in the following words :

The Union does not recognize Jewry as a race or a nation, for the conception of a nation implies and includes a series of signs of state construction and national individuality which are not to be found in the case of the Jews. Judaism represents an organized freemasonry, swindle and falsity. For us there are three social evils in the world, which are interconnected: freemasonry, Bolshevism, and Judaism. The Union therefore considers a national renaissance impossible until Judaism is expelled.

And the "Union of Young Nationalist Legions", which we have already mentioned, declares:

No foreigners, among whom we include the Jews, may obtain a refuge in our country.

Berlin's influence can most clearly be traced in the case of the Bulgarian Workmen's National Socialist Party, founded by Christo Kuntscheff in autumn 1932, as its programme corresponds to that of the N.S.D.A.P. in all important points. The emblem of this party is the swastika with the Bulgarian lion. Finally, German National Socialism's influence on Bulgarian internal politics is unusually strong; Berlin's representative is considered to be Deputy Zankoff, who frequently attempted to establish a dictatorship in Bulgaria on National Socialist lines. These attempts failed, mainly in face of the opposition of King Boris; it may be said 


\section{GERMAN T PUSHES SOUTH-EAST}

that in general here, and in the other countries of Central and South-East Europe-despite the exception established by Greece- a monarchy can be considered to be one of the most formidable obstacles in the path of the establishment of dictatorships.

The close co-operation of German foreign policy with the fascist organizations of nearly all the countries in South-East Europe can be demonstrated again and again; the fact that these fascist organizations, called to life and conducted on the German pattern and with German assistance, nearly all include in their programmes the demand for the oppression of all Minorities and consequently also of the German Minorities strewn over these countries, has never induced National Socialism to renounce its co-operation with these groups, movements, and parties. Still less have the complaints of the German Minorities had any success, where the aim of such co-operation was to further the German policy of expansion by increasing the influence and power of the fascist organizations in South-East Europe by all available means.

This co-operation, which is openly admitted by German National Socialists, shows that the demand for the protection of the German Minority in SouthEast Europe does not serve the interests of the Germans living there, but that on the contrary it is subordinated to the real purposes of the German foreign policy-in other words, to the endeavour to develop a mighty colonial empire on the line Berlin-Baghdad and consequently to the German push South-East. 


\section{Chapter XVIII}

MINORITY POLICY IN THE THIRD REICH AND

IN THE SOUTH-EAST

In his book My War Memoirs Dr. Edward Benes describes the Great War as a "fight for the democratization of Europe". In it he shows in detail how the protraction of the War compelled the Allies to give thought to the essential character of this war and to recognize the advantages arising out of a more consequent furtherance of the principle of nationality :

This showed the great allies the way to the small nations in Central Europe : these became their natural allies and valuable helpers in the struggle for new political aims and ideals. At that time, too, it began to be realized what panGermanism is. From the angle of the philosophy of nationality pan-Germanism was an abortion. Just as the national idea was an immediate demonstration of the esteem of the man of one nationality for the man of another nationality and consequently a manifestation of philosophy of pure philanthropy, pan-Germanism is a philosophy of force, of inhumanity. Pan-Germanism as formulated by German philosophers and politicians beginning with Lagarde was a denial of the modern idea of nationality, of the principle of the equality of men and nations, of democracy and a denial of all the political and social theories represented by Great Britain, France, Italy and the U.S.A. before and during the Great War. Consequently, in one respect the struggle between the Central Powers and the West was a fight for the existence of these nations, for the realization of one of the greatest ideas of this war-the idea 
of nationality - and for a practical political reorganization of future Europe.*

And when, shortly after, Beneš states that the idea of nationality is simply a child of democracy, one involuntarily asks what is the attitude of the present German nationalism, which has been disturbing Europe since 1933, and especially of its Minority policy, to the true principle of the nations' right to self-determination, which in its very essence is a democratic principle through and through.

If we examine this question we find that the Minority policy pursued by the Third Reich has nothing in common with the original humanitarian principle of all nations' right to self-determination, if only for the reason that the new German nationality policy is essentially undemocratic. This, however, is the case, for it lays down two different kinds of rights. It interferes with the internal, foreign, economic, and cultural policies of the Central and South-East European states, that is, it combats the principle of non-intervention constantly emphasized internationally, especially by Great Britain, and claims special rights for certain citizens of foreign countries who in some way or other are in particularly close sympathy with its undemocratic ideology.

On the other hand, however, it refuses to respect even the most primitive rights of those German citizens who from national or other motives are not willing to subject themselves to the Third Reich's panGermanism, for the ruling system in Germany discriminates against the Minorities living in the Third

* This passage is apparently missing from the abridged English translation of this work. 
GERMANT PUSHES SOUTH-EAST

Reich itself, which in many cases have for over a thousand years been recognized there as citizens. In no case, however, is this done in a way so abhorrent to public opinion all over the world as in the treatment of the Jews and half-Jews living in Germany, for whom no other reproach can be found than that they, according to the National Socialist racial theory, which is not endorsed by science and its most prominent authorities, are aliens in present-day Germany, in other words represent a national minority. This would be just the case, however-and the same applies to the other "non-Aryans" living in Germany today, for whom exceptional discriminative legislation has been created-when they would stand in most urgent need of international protection in the spirit of the principle of nationality.

A government and system which is apparently founded on the principle of nationality, and in the name of this nationality principle makes a long series of claims in other countries, particularly in Central and South-East Europe, is the first to be morally bound in the eyes of the world to prove within its own boundaries how seriously it takes the protection of nationality.

Germany's Minority policy, which so energetically strives for the "protection of Germans abroad", consequently knows neither a uniform moral nor a uniform right. While the Third Reich itself suppresses by forcible means all that, according to the very dubious principles of its new racial theory, is described as "non-German", on the other hand, under the slogan of the protection of Germans abroad, it utilizes the essentially democratic principle of nationality for purposes which have nothing in common with the 


\section{GERMANT PUSHES SOUTH-EAST}

true right of all nations to self-determination, their peaceful life with and among one another, nor with an international co-operation of state entities. The prime condition of a moral justification for the protection of the Germans abroad on the part of the system ruling in Berlin would be to prove that an equality of the rights of all people living in Germany itself, irrespective of race, language, religion etc., is unconditionally recognized and carried out in practice in a manner to deprive critics of any possibility of expressing even the slightest doubt regarding the observance of these principles of tolerance, created by the Great War, within German territory.

But this, however, is quite incompatible with the ideology of pan-Germanism which, since I933, has assumed dominion over Germany's internal and foreign policy. One must, therefore, agree with Beneš when he describes pan-Germanism, in the part of his book already mentioned, as a negation of the modern idea of nationality, of the principle of the equality of men and nations. As it is, just as at the time of the socalled "All-Germans", pan-Germanism in its present form expounds a "ruling race", to which it grants special allegedly inherited privileges to the detriment of all the individuals and nations who do not belong to this Nordic ruling race.

From this ideological point of view, too, it can be seen that Germany's Minority policy does not work for the benefit of democracy and international peace, but rather for the acquisition of special privileges for Germandom or those individuals and nations whom the National Socialist ideology, according to its peculiar racial theories, recognizes as pure-blooded Germans.

The young nations in Central and South-East 216 


\section{GERMANT PUSHES SOUTH-EAST}

Europe, who are indebted for the attainment of the independence of their states at the end of the War chiefly to the principle of nationality, that is to say to the idea of all nations' right to self-determination, have from the very beginning sought to assure the democratic rights of the Minorities-and consequently also of the Gernian Minorities-domiciled on their territory, which rights are guaranteed them by international treaties, but on the other hand the legislature of the German Reich itself, at least sincc the inauguration of National Socialist rule, is characterized by its consciously and intentionally unequal treatment and by its rejection of the democratic principle of nationality.

The German Minority policy is conceived so as to demand the advantages of democratic principles from other nations and in other states, while the system ruling in Germany itself rejects these democratic principles and in innumerable laws and decrees discriminates against all those citizens who do not conform to the standards determined solely by its own racial ideology.

The contradiction which is evident here and by which the new pan-Germanism creates twofold rights and twofold morals according to necessity, shows quite as clearly as the close connection between National Socialism and the fascist movements in the Central and South-East European states that the so-called protection of the Germans abroad is not claimed from a conviction of Germany's own fair claim thereto, but that this Minority policy serves quite different aims.

These aims, however, are confined entirely to the sphere of foreign policy, and the Minority policy followed by the system ruling in Germany since 1933 
in reality serves the "Drang nach dem Südosten", and therefore, as it did decades ago, serves the German efforts at expansion, which are the worst menace to the peace of Europe. These relations are concealed by all the methods available to propaganda, but anyone who examines on the one hand the innumerable ties between National Socialism and foreign fascist movements, and on the other hand the contrast between the racial and nationality policies pursued inside and outside the German boundaries, can see clearly that these are nothing but two different methods of furthering the same aim, viz., the German push South-East.

After the conclusion of the Great War the Central and South-East European states submitted themselves to Minority treaties intended to prevent oppression of national Minorities. There can be no doubt, however, that in almost all these states certain mistakes were made in nationality policy, and the new international legislation, to which they arc indebted for their existence in the present form, had occasionally to be appealed to in order to enforce an unconditional observance of the Minority treaties. Germany, on the other hand, like the other Great Powers, was not subjected to international stipulations regarding Minority protection, for in consideration of the high standard of culture of the German nation and after the victory of German democracy over the All-Germans and Hohenzollerns, who were the cause of its defeat in the Great War, it was regarded as unnecessary to impose these obligations on the German Republic.

When, later, Germany joined the Leaguc of Nations, this was regarded as a still better guarantee of the adoption of fair and democratic principles in the treatment of the Minorities domiciled in Germany, all 218 
the more so as the racial ideology which came to the fore together with National Socialism only in 1933 was unable to gain any powerful position in the Republic of Weimar. Later this proved to be a great mistake, for Germany, which, after National Socialism's rise to power withdrew from the League of Nations, subsequently developed pan-German tendencies in a more and more pronounced form.

While democratic principles, especially in the question of nationality, asserted themselves more and more distinctly in the Central and South-East European states in spite of the temporary deviations already mentioned, German National Socialism realized what a useful instrument the "Drang nach Südosten" would find in the slogans of the protection of Germans abroad, the security of the Minorities, and others. In point of fact, certain sections of the public, which could not or would not understand the true state of affairs, at times contributed towards facilitating National Socialism's utilization of these methods of propaganda as an instrument of the advance thrust directed south-eastwards. Only relatively late, and slowly, was the true character of this struggle against democracy by the use of democratic slogans seen in the correct light, and that mostly only at a time when considerable sections of the German Minorities in the South-East had already become a valuable means of undermining the democratic principles in the Central and South-East European states.

The struggle with democracy carried on by National Socialism in Central and South-East Europe, in which, among other instruments, the Minority policy is utilized, although simultaneously the fascist organizations in Hungary, Roumania, Bulgaria, and elsewhere 
are financed and supported, is, however, at the same time a struggle against the maintenance of peace among the European nations. German National Socialism exploits the Minorities in a number of the states on its borders to facilitate its imperialist advance thrusts.

At the same time, however, it can be noticed that all support of the Minorities is always abandoned immediately the governments of the neighbouring states in question comply with certain wishes of Germany's foreign policy. The example of Poland, which has already been mentioned, is particularly characteristic. In Lithuania the Memel Germans and their organizations were utilized on more than one occasion to provide supporting points against Russia in this small but strategically important Baltic state.

A typical example is the relations of Sudetic German National Socialism in its various forms to Berlin, which have been demonstrated again and again. When the old nationalist parties of the German Minority in Czechoslovakia were dissolved as hostile to the state, the Henlein movement, which was called to life according to the "Führer" and totalitarian principles, proved to be a valuable instrument for advancing the claims of Berlin's foreign policy, such as, for example, the endeavour to dissolve the friendship between Prague and Paris, termination of the CzechoslovakRussian defensive pact registered with the League of Nations, loosening of the ties of the Little Entente, etc., which would be more to the benefit of Berlin's foreign policy than of Czechoslovakia's.

Almost all over Central and South-East Europe we find close co-operation between the non-German fascist or semi-fascist movements and the German Minority groups supported by National Socialism 
GERMANY PUSHES SOUTH-EAST

wherever the interests of the Third Reich's foreign policy, that is of the push South-East, are to be furthered. At the same time it is evident that those groups and parties of the German Minorities in the South-East European states which aim at as close a co-operation as possible with the predominant nation, and reject totalitarian and fascist tendencies, are most ruthlessly combated by the Third Reich's propaganda and Berlin's foreign policy, and stigmatized as "traitors to the nation".

The German abroad is deemed worthy of protection by Germany's Minority policy only as long as he opposes the government of his own state and the tendency to lead a peaceful and harmonious life with the nation representing the majority in the state whose citizen he is. The German abroad who thinks and acts democratically does not, in the National Socialist conception, deserve the sympathies of the Reich's policy. His political and economic co-operation for the general benefit of his homeland makes him suspicious in the eyes of National Socialism, as he cannot be exploited as an instrument of the pan-German policy of expansion. The struggle against him is conducted most ruthlessly. Illegal methods, such as abduction, business boycott, and so on are no rare phenomena; here, too, the German National Socialist parties abroad and the fascist groups which spring up in the countries of South-East Europe are frequently utilized to interfere in the internal conditions of the Central and SouthEast European states in order to further the aims of Germany's foreign policy, characterized by the push South-East.

A comparison between the discriminative Minority policy pursued within the boundaries of Germany on 
GERMANT PUSHES SOUTH-EAST the one hand and the "protection of the Germans abroad" on the other is a further distinct proof of the fact that the "Drang nach Südosten" and not feeling of cultural or national affinity is in the foreground when National Socialism plays a part in the Central and South-East European states' political, economic, and cultural life. The expansion along the line BerlinBaghdad and the development of a mighty selfcontained colonial empire, ruled over by Berlin on National Socialist principles, is the leit-motif of the German policy in the Minority problems as well. The weakening of the small nations in Central and SouthEast Europe which, in consequence of the defeat of Germany-that is to say the defeat of pan-Germanism -in the Great War, have won independence for their states, is one of the most important pre-suppositions for the preparation of the German imperium, which is the true aim of the National Socialist policy just as it was the dream of the Hohenzollerns and pan-Germans. 


\title{
Part Five
}

\author{
The Push South-East and the \\ Democracies of Western Europe
}





\section{Chapter $X I X$}

THE SEA-ROUTE TO THE EAST AND THE LAND ROUTE TO ASIA

ONE of the routes from Western Europe, particularly Great Britain, to Asia and the heart of the British Empire, India, runs by sea via the Mediterranean, both ends of which were guarded strategically and economically by the Straits of Gibraltar and the Suez Canal. The tense "were" is of especial importance, as it will be remembered that the opinion expressed by Mussolini, to the effect that for Great Britain the Mediterranean is only a traffic route, though a particularly important one, was at once countered by the British statement that it is not only a traffic route, but the very artery of the British Empire. Any examination of the geographical and strategical conditions of the British Empire, particularly historically, will confirm this British point of view.

Italy and its ally Germany, too, which are both admittedly trying to make the line Rome-Berlin into the new European axis, if not that of the entire Old World, may be supposed to see clearly how fateful the line from Gibraltar to Aden is for Great Britain, and in recent years it has been the endeavour of the Italian dictatorship, with the passive, and at times very active, co-operation of its German ally, to "ligate" this artery by gaining footholds at the Eastern and Western 
gates of the Mediterranean. Fascist Italy's conquest of Abyssinia has seriously endangered Great Britain's hitherto undisputed dominion over the Suez Canal. This became still clearer in 1936 and 1937, when the joint intervention of Italy and Germany in the Spanish civil war encroached upon Great Britain's supremacy in the Mediterranean by threatening the Straits of Gibraltar.

It must be clearly realized that a new and extraordinary change in the distribution of power would be necessary to do away with this permanent danger to the two gates of the Mediterranean. Every attempt to regain control over Gibraltar and the Suez would in practice encounter the opposition not only of Italy, but also of its ally the Third Reich; it may be admitted that Germany's support for Italy's plans in the Mediterranean would hardly be given officially, just as the help given by Germany to Fascist Italy's thrust towards Suez and Gibraltar was mostly indirect, though nevertheless very effective. If we now mention that the damage to France's strategic position in the Western Mediterranean from Germany's rearmament, Italy's ever open enmity and the happenings in Spain are at least as considerable as the deterioration in the value of the possible support for Great Britain from France-a country with uncertain and even dangerous neighbours on at least three of its frontiers-it becomes clear that the sea-route leading through the Mediterranean to Asia can no longer aspire to its former importance for Great Britain.

It may be admitted that Britain's rearmament programme, the growing increase in France's military and naval power, and the economic and military decrease in Italy's potential war-value, with a whole 226 


\section{GERMANX PUSHES SOUTH-EAST}

concatenation of other considerations, show the Mediterranean situation to be not quite as bad as has been here roughly sketched. The other considerations include, for example, Britain's growing influence in the Eastern Mediterranean, its treaty with Egypt, certain guarantees in Palestine, the increasing influence gained in Greece, Yugoslovia, etc., but even if all these factors are taken into consideration the conclusion cannot be avoided that it is no longer possible to speak of Great Britain or the two allied western democracies' clear and undisputed supremacy over the Mediterranean and consequently over the sea-route to Asia in the same way as, for example, during the Great War and afterwards.

Consequently, it has become more and more important for the two Western Powers, particularly Great Britain, to decrease the predominant strategic importance of the Straits of Gibraltar and the Suez Canal, or in other words of the Mediterranean. The necessity to decrease the dependence upon the sea-route, however, involves the necessity to increase the supremacy over the "transversal Eurasian axis"-the old strategic route leading, like the sea-route, to the heart of Asia, which in consequence of the continually growing importance and security of the Mediterranean route had lost importance in much the same way as the very difficult and expensive sea-route which might be used to connect Great Britain and the French Channel ports with Asia via the Cape of Good Hope.

The "transversal Eurasian axis" is in practice, however-and it is the German geography and strategy which have so often demonstrated this fact -nothing more than the shortest land route between the Atlantic and the Indian Ocean, which represents 


\section{GERMANT PUSHES SOUTH-EAST}

the shortest land route from the North Sea (Hamburg) to the Persian Gulf (Basra). But this land route runs through the Black Sea, and every power utilizing it must take either the southern route over the Bosphorus and the Dardanelles or the northern route along the south-west spurs of the Caucasus. The absolute length of these two routes is approximately the same. On the southern route the German advance south-eastwards would meet the combined forces of the Little Entente and Balkan Entente, possibly those of Italy too. While these joint forces would be approximately equal to the German military power, the northern route, as Emanuel Moravec shows in his work on the strategic importance of Czechoslovakia for Western Europe, would be much more difficult from the German point of view, as the German advance would here be opposed by the Polish and above all the gigantic Russian forces, which can be estimated as at least twice as strong as those of Germany.

From a purely strategic angle, therefore, everything would speak for the southern route, and the policy followed by Germany under the National Socialist régime, which has been detailed here on several occasions, shows quite unequivocally that everything is prepared for the use of this southern route in case of emergency. The extraordinary importance of Bohemia and the Danube Basin in checking the German advance south-east is therefore quite clear. But even if we allow for what, in view of the distribution of power, is the very improbable eventuality that the northern route would be preferred, it must be borne in mind that the line through Poland and Russia would also run along the flank of two Little Entente states, Czechoslovakia and Roumania. In any case, therefore, the importance 
GERMANT PUSHES SOUTH-EAST of these states in checking the German advance to Western and Central Asia is unmistakable.

Any far-sighted policy which is not satisfied with the problem of the moment and the apparent solutions which offer themselves, therefore, must consequently recognize the extraordinary importance of Central and South-East Europe, but above all the two Little Entente states, which in any case would block the German land route to Asia.

There remains, of course, the alternative of an increased British and French influence on the countries in the Eastern Mediterranean basin. If any considerable importance is attached to this alternative it must be extended to the chain of small and medium-sized states separating Germany from Russia, which represent the land route from the Baltic to the Adriatic, and here, again, it is, in addition to Poland, primarily Central European states, above all the two Little Entente countries, Czechoslovakia and Yugoslavia, which gain enormous strategic importance. Any combination based on the necessity of lessening the dependence on Gibraltar and attaching more importance to the land route to Asia as a whole, at least as an auxiliary route, than was necessary while the former clear distribution of power in the Mediterranean lasted, must consequently recognize the significance of the Bohemian basin and therefore of Czechoslovakia as the indispensable keystone of the communication to be maintained between Western Europe and Asia.

Every blow at Central Europe, particularly the Little Entente, must inevitably weaken the land route to the East just as much as the Italian and German attacks on the strategically important points in the Mediterranean have done the sea-route to Asia. The 
maintenance of the present distribution of power in Central and South-East Europe, particularly the assurance of the peaceful continuation of the Little Entente and the Balkan Entente is therefore by no means, as has often, though very shortsightedly, been assumed, a purely Eastern European concern, but on the contrary these questions are of eminent importance for the two Western European democracies, particularly Great Britain. This interest is mutual. Central and South-East Europe are extraordinarily interested in the military, political, and economic strengthening of the two Western democracies, for they alone are in a position to assure the maintenance of peace against unprovoked attacks from the factors of disturbanceItaly in the Mediterranean, Germany in South-East Europe.

The West, on the other hand, is just as interested in the maintenance of peace in Central and South-East Europe, for every attack on the small and mediumsized states in this region must necessarily result in a further weakening of the world power of the Western European democracies. At this point the interdependence, from a purely strategic angle, between the maintenance of peace in the West and in the East is evident. The Berlin-Rome axis is formed by states whom their entire structure and existing régimes induce to found their hopes on expansion and the "adventure" of war. Such expansion would naturally be directed along the line of least resistance, so that the Eastern and South-Eastern states, in spite of the exertion of all their not inconsiderable forces, are the first to be threatened by the dynamics of the two totalitarian states. Following the considerable threat to the searoute to the East, a successful attack on these states 
GERMANT PUSHES SOUTH-EAST would block the land route to Asia, too. The methods adopted in such attacks are well-known from the events of recent years. The achievement of a position of cconomic predominance, the kindling of internal political conflicts, and intervention in them at the given moment, are the most dangerous preparations for such a campaign. 


\section{Chapter $X X$}

\section{WHICH IS IT TO BE? LONDON-PARIS OR ROME-BERLIN?}

THE statement made by Mussolini that the line RomeBerlin will become the new European axis can certainly not be accepted without any argument. On the one hand it must be admitted that the Austrian problem, for example, is not yet completely solved and that for this reason there is no unbroken line from Rome to Berlin to become a European axis. And it must further be admitted that the interests of Germany and Italy in Central and South-East Europe by no means coincide in all points and that in various Balkan countries there are actually violent conflicts in the economic and political spheres, under the surface, between the Italian and the German orientations. But on the other hand, it must be pointed out that Italy and Germany work together for a common purpose in the Danube Basin and the Balkans.

Although there is no knowing how long this bond of common interests can be preserved, the facts show clearly that no serious resistance is offered by Italy to the German push South-East and that Italy's south-east policy, which, like Berlin's, combats the influence of the Western democracies in this part of the Continent, actually does support the German push South-East. Under these circumstances it is less important to prove that in the distant future conflicts in the South-East between Berlin and Rome are inevitable-this thesis in itself is probably correct-than not to close one's 
eyes to the fact that the Italian backing which Germany is gaining in the Balkans is for the time being of inestimable value to the German push South-East.

Like the German policy in this part of the Continent, the Italian policy aims at ousting the political,strategic, and cconomic influence of Great Britain and France and, by co-operation with Berlin, on the one hand to allow fascism to expand eastwards, on the other to strengthen the position of Germany and Italy in conflicts with Great Britain and France by preventing their allies in Central and South-East Europe from supporting the Western powers in the event of such a conflict. In this sense the Berlin-Rome axis can be regarded as a reality in European politics, although various differences of opinion between the two dictatorships have not yet been settled; and in this sense the Berlin-Rome axis is of inestimable significance for the German push South-East, as many hindrances in its path are overcome by the Italian support.

If we examine from this angle the bilateral pact of non-aggression concluded in March 1937 between Rome and Belgrade, we cannot avoid the conclusion that, in spite of the traditional friendship which indubitably binds the Yugoslav and the Czechoslovak nations, this advance was achieved by the Italian politicians at the cost of the Western democracies and was quite as useful to the German push South-East as to the Italian interests themselves. For in the first section of the Italo-Yugoslav treaty the two neighbours guarantee not only each other's land and sea frontiers, but also undertake the obligation, in the event of one of them being attacked by one or more Powers, to abstain from any action of any kind which might help the attacker. 


\section{GERMAN PUSHES SOUTH-EAST}

Although this text in its purely defensive form at first sight appears to be harmless, it assumes a quite different aspect when one realizes the practical possibilities which might arise out of it. For if Italy comes in any way into conflict with one of Yugoslavia's friends or allies-and recent years have shown repeatedly that it is difficult, if not entirelyimpossible, to decide impartially who the aggressor is-it will in future no longer be compelled to fortify its Adriatic boundary against Yugoslavia, which up to now has been under this constant threat.

In practice this would enable Italy to muster considerably larger forces against France and Great Britain in the event of such a conflict. Large naval units, which Italy would otherwise have had to keep in Ancona, Pola, and the other Italian ports, would become free for a conflict in the Western Mediterranean basin. The same applies to the security of the Albanian frontier, which Yugoslavia has guaranteed in this treaty. If it is realized that Albania is politically, economically, and militarily as good as completely under Italian control, and can in fact be regarded as paramount to Rome's Balkan colony, it will be evident that this agreement allows a complete military exploitation of the Italian position in Albania, and that it would be a mistake to assume that the Belgrade pact represents to a certain extent Mussolini's renunciation of the mare nostrum.

It will be remembered that only in 1935, when King Achmed Zogu of Albania wished summarily to dismiss his British engineers and experts and to replace them by Italians, at the time of the so-called "Durazzo conflict", the dispatch of a few British warships was sufficient to induce Rome to give up its desire. At that 
GERMAN PUSHES SOUTH-EAST

time it was seen that the Little Entente and the Balkan Entente were able to find support in the Western democracies which in an emergency would be by no means so insignificant as Berlin and Rome tried to make out; the psychological valuc of this demonstration should not be underestimated. Today a glimpse at the map shows clearly that the Adriatic can be completely closed if Italy posts relatively small forces on the west coast (Brindisi) and on the east, in Valona (Albania).

Italy's diplomatic and political successes in the Balkans and the Danube states protect the flanks of the German push South-East in a very considerable measure ; the idea of the "Berlin-Rome axis", though frequently used only as a slogan, occasionally gains concrete importance when it is realized that the cooperation between Italy and Germany functions in Central and South-East Europe at the cost of the axis Paris-London, of the theory of democracy, of the League of Nations, and of the maintenance of European peace generally.

These hard facts, shown here on the example of the Italo-Yugoslav treaty, cannot be got over by emphasizing the argument, in itself correct, that in Southern Tyrol, Austria, Hungary, Roumania, Bulgaria, and elsewhere many problems of the German-Italian antitheses have not yet been solved. The German push South-East has indubitably been considerably furthered, at the expense of the Western Powers, by Berlin's cooperation with Rome. If the importance of Germany's tacit support for the Italian campaign in Abyssinia and its much more unequivocal part in the Spanish conflict is admitted, it would be nothing but blindness to realities to deny the significance of Italy's help to 
the German push South-East. The world is faced by the fact that German imperialism's lust for expansion along the line Berlin-Baghdad, which since 1933 has regained more and more of its former vigour, has found an important ally in Italy, and that the Berlin-Rome axis is much more than a mere slogan, at least in so far as it continually hampers the endeavours to preserve peace made by the Franco-British co-operation.

In the question whether the line Berlin-Rome or the line Paris-London will become the true European axis lies at the same time the answer to the question of the maintenance of European peace. Slogans can frequently have a dangerous effect and lead to erroneous conclusions as they have a tendency falsely to simplify very complicated questions. The slogan of the axis Berlin-Rome coined by Mussolini has, however, at least the advantage that it clearly indicates to anyone contrasting it with the Franco-British co-operation where the peace-loving forces in Europe and where the disturbers of peace are to be sought.

While German National Socialism morally (and in many instances materially and militarily as well) supports the continually increasing Fascist expansion-thrust in the Mediterranean, the Third Reich's peace-disturbing policy enjoys the full support of the head of the Italian Government, who is clear that (with the possible exception of the problem of the Brenner frontier) he must support Germany and the other aggressive Powers as well, in order to strengthen his own position vis-d-vis the Western Powers, obtaining as high as possible a price for a cessation of this support of the aggressors particularly from the Anglo-Saxon Powers.

The immediate consequence of this co-operation between the aggressors can clearly be recognized in 236 
GERMANT PUSHES SOUTH-EAST the fact that the peace-loving Powers are forced to make higher and higher cxpenditure on armaments. In President Roosevelt's speech at Chicago on $5^{\text {th }}$ October, 1937 , in which he summoned the peaceloving proportion of mankind, which he estimated at ninety per cent., to resist the other ten per cent., who, breaking their treaties, seek to destroy the rights and liberty of other nations by force of arms, he also said that in those nations which are accumulating armaments upon armaments, apparently for the purpose of an attack, and in those nations which fear aggressive action against themselves and their security, a very high proportion of the national income is now directly expended on armaments. The percentage varies between thirty and fifty per cent.

This apparently insoluble problem, which has long since affected Africa and Asia, too, owes its existence indubitably to the mutual assistance of the two European Powers which, if not bellicose, at least constantly threaten attack.

In European politics the German push South-East joins the dangerous association established between Italian Fascism and German National Socialism to procure a free hand in the eastern half of the Continent for these states in their lust for expansion. This "free hand in East and South-East Europe", however, cven though it is prepared by ever so harmless-sounding pacts, constitutes no small danger for the West. It would be a very short-sighted policy and pregnant with fatal consequences to underestimate the influence on the security of Western Europe of the direct and indirect support for the German "Drang nach dem Südosten" by the very real co-operation between Rome and Berlin. 


\section{Chapter $X X I$}

THE EUROPEAN EQUILIBRIUM AND THE SOUTH-EAST

THE endeavour by the conclusion of bilateral treaties to undermine and finally almost entirely to destroy the system of collective security in Central and South-East Europe, which is the most likely to bring about really permanent order in European conditions, is one of the gravest dangers for the peaceful development of the continent. The German (and also the Italian) policy in Central and South-East Europe, in contrast to the principle of collective security based on the League of Nations' treaties (which unfortunately fails only too often for lack of adequate guarantees), aims at concluding individual agreements with as many small and medium-sized states in this territory as possible and in this way rendering international measures against the aggressor less and less practicable. The resistance of the states in Central and South-East Europe to the temptation of the bilateral treaties offered them by Berlin and Rome has been decidedly weakened by the bad experience which they gained on the occasion of the imposition of the League of Nations' sanctions against Italy. This fact is accordingly utilized to facilitate the German push South-East, according to the old method of divide et impera, which can be traced throughout the history of Prussia.

This method gained success after success until the peak of the German armament capacity had been $23^{8}$ 


\section{GERMANT PUSHES SOUTH-EAST}

reached. In the South-East the idea of obtaining protection against possible attacks by German National Socialism or Italian Fascism by means of bilateral pacts penetrated deeper and deeper into the classes which decide the foreign policy and into the widest masses of the population, the more so as each of these states, weakened by the economic depression, sought ways and means of maintaining its neutrality in the event of a conflagration.

No examples from history are needed to demonstrate that in practice, in the event of serious complications, this aim can, if at all, be achieved only in exceptional cases. It must, however, be admitted that the moral responsibility of the South-East European governments towards the population of their own states increased more and more whenever the apparent possibility of protection through a bilateral treaty with the redoubtable aggressor presented itself. Allusion to the failure of international measures and especially of the Geneva institution indubitably benefited the German endeavours to undermine the system of collective security in the South-East, more especially because, as has already been shown, care had been taken, by interference in the internal politics of the states concerned, to keep the governments permanently under more or less intensive pressure.

It would be a mistake to assume that the distinct slackening of Germany's armament, which began to be noticeable in about 1937, and on the other hand the progressive strengthening of the military, naval, and other forces of the Western European democracies, would alone be sufficient to make any considerable change in the situation in South-East Europe. Only when the conviction has gained strength that, collective 
security having failed, the considerable increase in the great democracies' armaments will really be utilized against any aggressor seriously threatening the peace of Central and South-East Europc, can the system of concluding bilateral treaties, which is opening up the path to Asia for the fascist states, lose its attraction.

In spite of the fact that it was quite evident from the developments in Spain, Great Britain's rearmament programme, etc., that a change in the distribution of European power is impending, it could be noticed that even in 1937 the conclusion of bilateral treaties with Germany and Italy was still regarded by certain states in Central and South-East Europe as a practicable way of purchasing the security which the Geneva institution and the democratic Powers behind it seemed unable to offer. Germany's push South-East can hardly be checked by the increase in the strength of the Western Powers alone. The endeavour to seek a way out of the difficulties presented by internal politics and the economic situation at home by directing the available forces outwards along the line of least resistance may even be intensified still further, for there have always been two versions of the German military staff's war plans, one directed eastwards and one westwards, and even the programme laid down for the German war policy in Mein Kampf will hardly prevent the military Powers from adapting themselves to the situation of the moment.

The system of concluding as large as possible a number of bilateral treaties in South-East Europe to prepare the way for the German military campaign in the South-East is, however, likely to cause increasing confusion in the entire political situation and to render a return to the system of collective security more and 
more difficult. The European equilibrium becomes more and more remote if a considerable number of states which conclude a variety of bilateral treaties are given the possibility of reserving judgment in any emergency. The progressive dissolution of the system of collective security created by the League of Nations involves at the same time the gradual destruction of any European equilibrium. The conclusion of numerous bilateral treaties has given rise to a state of general uncertainty as to the line of action which would be taken by each individual state in the event of a serious conflagration in Europe, which contributes considerably towards poisoning the general European atmosphere. It is just this uncertainty which very greatly facilitates the German efforts at expansion south-eastwards, which under Hitler has remained the basis of the German foreign policy as it was under Wilhelm II.

How can this danger, which is accentuated by the growing uncertainty and general mistrust, be averted ? If it is realized that European cquilibrium can be preserved only if the aggressor can under all circumstances reckon with immediate international reprisals, it will have to be admitted that the strengthening of the Western Powers' military resources alone is of just as little value as the--at least relative--deterioration in the potential war value of the attacking state.

Much more decisive is the fact that the feeling of insecurity, caused by the absence of adequate guarantees from Great Britain and France in the event of an unprovoked attack on the security of the Central and South-East European states, is vanishing from Central and South-East Europe. Under the constant pressure of the German menace, which, as has been shown, had a very material foundation in the sphere of politics, 
economics, interference in internal questions, etc., the small states ardently appealed for a restoration of collective security. This could be assured solely by a clear and open acknowledgment from the two democracies in Western Europe of their function in the European family, and by their leaving no room for doubt that they would oppose the German expansion south-eastwards if the existence of a state in the SouthEast were to be endangered by such an attack.

The uncertainty in the eastern part of the Continent necessarily continued, and grew, as long as the significance of the German push South-ciast was not clearly recognized in the West and as long as the West could not decide to utilize this recognition as a decisive factor in maintaining European equilibrium. Even the actual increase in the military strength of the Western Powers was unable to remove this feeling of uncertainty, and the consequence was the dangerous increase in the number of bilateral pacts concluded between states of unequal rank, which in an emergency would of necessity make the weaker state a victim to the stronger partner.

We have now arrived at the question which will be decisive for the future politics of Europe, that is whether security in the West can be preserved if the German lust for expansion is given a free hand in the South-East. The British and French rearmament alone has by no means solved this question. It is just the increasing disparity between the degree of armament of the states on the Rome-Berlin axis on the one hand, and those on the Paris-London axis on the other, which leads to frequent adoption of the standpoint that this changed state of affairs is sufficient to guarantec security in the West and that this would be still more 
the case if the German (and partly also Italian) expansion thrust were given an outlet in Central and South-East Europe.

As has been so frequently the case in the history of Europe, the question whether it is possible to localizc war in some part of the Continent arises in its full significance. If we consider the difference between the military and political situation in the West and East of Europe, this question can be considered identical with that of the divisibility of peace and war. The entirc importance of the German push South-East for the preservation of peace in Western Europe can be madc clear only by definite realization of the fact that peace is just as indivisible as would be the war which must needs arise out of the attempt to localize a European conflict. 


\section{Chapter XXII}

INDIVISIBLE PEACE-OR INDIVISIBLE WAR?

TIIE political methods of pan-Germanism are based, where the use of force is avoided, on the system of bilateral treaties. During the greater part of last century Prussia, by way of separate negotiations with weak or small states, brought one German state after the other under its hegemony by the conclusion of customs unions which were extended more and more from the sphere of economics into that of politics, and finally concluded this work-at least temporarily-by the creation of the German Empire in 1871 after a sanguinary war which, but for the skilful counter-moves of the other European Powers, would have spread over nearly the whole Continent.

Even after defeat in the Great War this policy of bilateral treaties was continued, and I have endeavoured to show elsewhere* how the signature of the protocol of the German-Austrian Customs Union on March igth, 1931 , is nothing less than an attempt (which, however, thanks to the intervention of the other Powers, was unsuccessful) to make Austria part of Germany not only economically, but politically, too. And actually many of the agreements registered in the protocol of this $193 \mathrm{I}$ "Anschluss" are almost word for word identical with

* Gerhard Schacher : Central Europe and the Westem World, p. 143 et seq. Allen and Unwin, London. 
GERMANT PUSHES SOUTH-EAST the treaties concluded by Prussia with Hesse-Darmstadt on February i $4^{\text {th }}$, i 828 .

This system of bilateral treaties is based on the consideration that the expansion of a large state at the cost of a small one can best be achicved by excluding the possibility of guarantees and support from third states and still more that of a super-state power such as the League of Nations. Rome of old already adopted a similar method, subjugating other nations and countries by giving them the harmless-sounding name of "socii". Often enough in history do we find the expansion-lust of large states towards smaller ones seeking to avoid war with these small states in order to prevent the intervention of third states, themselves powerful, developing in this system of bilateral treaties; in modern times it can nearly always be shown that the path to political aims is indirectly prepared by trade or other economic agreements. Fascist Italy, in particular, used this method of the conclusion of bilateral treaties to further its attempts at expansion in Central and South-East Europe, thus, for example, in the "Pact of Three" concluded in Rome on March I 7 th, I934, and in the Italo-Yugoslav treaty concluded in March 1937, where agreements properly economic always develop into the arrangement to follow the same lines in questions of international politics.

The whole situation results in this line being dictated by the contractual party which at the moment is stronger. Treaties of this kind are in conscious opposition to the principle of collective security and of the League of Nations, which de facto and de jure is excluded, the League of Nations pact not being mentioned and the registration of such bilateral pacts in Geneva not being agreed upon on the conclusion of the treaty. 
Where states desirous of expansion penetrate a certain territory politically and economically, therefore, international guarantees for the security of the small states sponsored by the League of Nations and other international agreements are rendered ineffective.

Germany, like Italy, is endeavouring to gain a "free hand" in East and South-East Europe, to oust the interests of the Western European states and those of the neutral democracies, or, in other words, by methods which are ordinarily used only in colonial politics to create so-called "spheres of interest" in certain parts of the European Continent and to prepare a gradual economic penetration and finally the political conquest of these states.

The German push South-East shows the National Socialist foreign policy's evident attempt to eliminate from the spheres of influence which Germany has created by the methods of economic and internal political penetration of the states of Central and SouthEast Europe the protection guaranteed to even the smallest member of the Geneva institution by the League of Nations, the Kellogg Pact, etc., and by this method continually to increase the dependence of the states in question on Germany. This most seriously endangers not only the independence of these Danubian and Balkan states, but the whole system of collective security.

Germany, which itself withdrew from the League of Nations on the grounds that its international equality is not observed, has adopted a policy in the South-East which is gradually destroying the equal rights in the League of Nations family actually enjoyed by the small states of this region, in the hope that the gradual weakening of the Geneva institutions will give rise to a 


\section{GERMANT PUSHES SOUTH-EAST}

corresponding strengthening of the German influence in Central and South-East Europe. Just this extension of Germany's predominant position is needed, however, to prepare the way for the achievement of the real aim, the creation of a German imperium extending from Berlin to Baghdad, as had been already planned under the Hohenzollerns.

At this point the endeavour of German foreign policy becomes clear : to eliminate international cooperation and consequently the preconditions of the maintenance of European peace at the cost of the security of the small nations of Central and South-East Europe. There exists, however, even apart from the League of Nations pact and from the great international treaties for the assurance of peace, a number of defensive treaties of friendship between the West and the East. In contrast to the above-mentioned bilateral pacts, which were consciously concluded on ground not covered by the League of Nations pact, these treaties, like, for example, the French alliance with Czechoslovakia and the other members of the Little Entente, with Poland and Russia, etc., merely supplement the League of Nations pact. This kind of treaty, which may be said to include, for example, the RussoCzechoslovak pact of friendship too, provides expressly that the League of Nations pact is to be applied priorily, that the new treaties of alliancc are to be expressly registered in Geneva, and even that their stipulations are valid only in so far as they are consistent with the stipulations of the League of Nations pact, which precedes them.

In contrast to the bilateral treaties (the character of which has already been described) which work against the idea of collective security, these treaties of alliance 


\section{GERMANT PUSHES SOUTH-EAST}

serve to complete the League of Nations pact. Between them and the Geneva institution there is no disagreement. Their main task lies in the practical execution of the idea of collective security, which the first category of pacts wishes to undermine and render ineffective.

This important distinction does not arise from any conflict of ideologies, but rather from a struggle between those tendencies which work for the maintenance of European peace and those which are making ready for the moment when this peace, by the use of carefully prepared measures of force, can be broken. The German south-east policy, therefore, has since 1933 been availing itself of a system which allows for the preservation of European peace only so long as the states interested in collective security do not oppose the German policy of acquiring increasing power in Central and South-East Europc. With the strengthening of the German predominant position in the South-East, however, the moment must automatically approach when the German push SouthEast comes into conflict with the defensive treaties which connect the small states of this region with the Great Powers enrolled in the League of Nations.

When this moment arrives the continuation of the German policy of cxpansion in South-East Europe will no longer be compatible with the preservation of peace. The push South-East must then inevitably decide the question of European peace ; it would be a dangerous delusion to assume that the problem created by the German penetration of South-East Europe can be localized there. If the idea born in the Great War of an international order, embracing the small and weak states just as it does the great Powers, is not to be 
GERMANT PUSHES SOUTH-EAST finally renounced, it will be necessary to give up the illusion that European peace is divisible. Germany's continual drive south-eastwards, which is by no means a passing phenomenon born of the special economic and political situation of National Socialism, will, therefore, again and again endanger the peace of the whole of Europe.

It would be false, too, to allow oneself to be delucled by the fact that National Socialist Germany, in which this push South-East is inherent, appears, on strategic grounds, temporarily to abandon its aggressive policy in Gentral and South-East Europe. The tension in the economic situation, the increase of the resistance put up by the opposition at home, and above all the decrease in the armament capacity, will result in a constant repetition of Germany's attempts to advancc the necessity for world-wide economic co-operation in order to lay claim on the help of the Western democracies, the League of Nations states, and above all of those states which are bound by pacts of friendship to the South-East European states which are the object of the German push South-East.

At such times, which have more or less the character of episodes, the German pressure on Central and South-East Europe seems to relax, and there even seems to be a willingness to negotiate about guarantces for the security of the states in Central and South-East Europe until such economic and financial help is granted. This will be especially the case whenever Germany's economic advance south-eastwards meets resistance arising out of the world trade boom. The rise in the prices obtainable on the world markets for agricultural and raw materials, which could be observed in ever-increasing measure since about 1936 , 
induces the Danubian and Balkan states to be inclined to free themselves from the fetters of the German clearing and compensation agreements, as they can sell their products without difficulty on the world markets, and that at more favourable prices, for foreign exchange bills.

Here, too, the importance of this slackening in the bonds imposed by Germany on their economic policy at a time of international trade depression should not be exaggerated. Since I933 Germany has acquired a predominant position on the markets of one state after the other in Central and South-East Europe in pursuance of the "Prussian system", so successful in the past, of concluding bilateral economic treaties which exclude or evade the most-favoured-nation clauses enjoyed by other states, following not only economic, but, and predominantly, political aims.

The impression may frequently be gained that these political aims are completely abandoned, that Germany is anxious to resume co-operation in world economics and desires to submit itself to international legislation in order to revert to the principle of collective security, if this abandonment of the policy of force is facilitated by adequate concessions from the Western democracies. In this way a pause for breath is gained. At such times there is an increase in the number of voices describing the entire German push South-East as a sort of bluff, which is shown up as such immediately the rearmament undertaken by the three great democracies in the West, Great Britain, France, and the U.S.A., to prevent an international conflagration, with the change in the international economic situation, reveals what is National Socialist Germany's really very weak situation politically, militarily, and economically. 
GERMANT PUSHES SOUTH-EAST

The mistake of confusing the cause with the effect, however, is only too easily made here. It must be admitted that the absolute and relative strengthening of the military, naval, and air resources of the West compel the fascist states-this applies to Italy just as much as to Germany-to postpone their plans of attack in the South-East. It should not be forgotten, however, that this retreat is beaten only in consequence of the considerable armament resources of the West, just as the plans of expansion south-eastwards would never have taken so definite a shape if the German south-east policy had been kept within bounds by a high potential war-value of the West and by clear indication of the indivisibility of peace.

The "wait and see" policy adopted by the Western states after National Socialism's rise to power led to a considerable increase in Germany's armaments and consequently to a chain of political successes in the form of breach of treaty. The dangerous delusion that European peace is under certain circumstances divisible has gained considerable ground in the West, too, and in consequence of this fact, again, the German push South-East was encouraged, even though involuntarily. National Socialism's entire conception of forcign policy as it is laid down, for example, in Hitler's Mein Kampf is based all along the line on the method adopted again and again throughout the entire Prussian and German history, that of "settling one adversary after" another".

These ideas have now been brought into confusion by the Western democracies' recent clear expression of their intention to counter the German rearmament by other, far greater armaments - to an extent which purely economic reasons render impossible for 
Germany-on the part of the peace-loving states which profess the idea of collective security. If this intention relaxes or its effects are weakened by financial and economic help granted by the West, which would enable Germany to improve the relative standard of its armaments in comparison with those of the other European, non-fascist states, the delusion of the divisibility of peace would once more be encouraged, A weakening of the German push South-East is repugnant to the nature of National Socialism. It is accepted "of dire necessity" as long as the growing armamentcapacity of the West and the emphasis laid on the thesis of the indivisibility of peace compel Germany to a temporary renunciation of its thrusts south-eastwards.

Immediately onc of these two factors were eliminated fresh vigour in Germany's push South-East would indubitably have to be reckoned with. A slackening in the pace of rcarmament in the West or tacit support of the false belief that peace is divisible would inevitably lead to fresh advance-thrusts along the line BerlinBaghdad, strengthen the German expansion-thrust, weaken collective security, and consequently lead finally to a threat to the peace of all Europe, and particularly to the situation of the Western Powers.

The German thrust south-east is and remains the greatest danger to European peace and international economic co-operation. It has achieved this position in international politics because in it National Socialism's exaggeration of its own political, economic, military, and intellectual forces have been able to find clearest expression. The liquidation of the false investments systematically made in Germany (not only in the sphere of economics) will yet cause the whole 
GERMANY PUSHES SOUTH-EAST world, and Germany in particular, considerable difficulty. This is not the place to decide whether it can be achieved by any other method than by the abolition of the régime now in force. But at all events it is in the interest of the world that these problems are not "solved" at the cost of world peace. Recognition of the fact that European peace is indivisible and of the neccssity for a final and lasting termination of the period of Germany's exaggcration of its own armament capacity, which scriously endangers this peace, is indispensable, if the German push South-East is not to plunge the world into fresh confusion, whose outcomc no one could foresee.

THE END 


\section{SELECTED BIBLIOGRAPHY}

IN addition to official publications of diplomatic records, statistics and similar material, I have made considerable use of the following works :

Hamilton Armstrong: Europe Between Wars? New York, 1934.

Amédé Badesco: Paris sao Berlin (Paris or Berlin). Bucarest, 1936.

Felix Behrend : Das grössere Deutschland. Leipzig, 1929. Edward Beneš : Der Aufstand der Nationen. Prague, 1928. The Problems of Czechoslovakia. Prague, 1936. Gedanke und Tat. Prague, 1937.

B. BošKovič : Der Balkan und der internationale Imperialismus. Moscow, 1936.

L. BROAD and L. Russel: The Way of the Dictators. London, 1935.

Dr. Lavo Cermelj : Life and Death Struggle of a National Minority. Ljubljana, 1936.

Josef Chmelar: The German Problem in Czechoslovakia. Prague, 1936.

Winston Churghill : The World Crisis, 1911-i8. London, I923-9.

John O. Crane : The Little Entente. New York, I93I. Lord Davies: Nearing the Abyss. London, 1936.

Gerald Druce: In the Heart of Europe-Life in Czechoslovakia. London, 1936.

Walter Duranty : Europe-War or Peace. London, 1935. G. E. R. Gedye : Heirs to the Habsburgs. Bristol, 1932. Gravelli : Hitler, Mussolini und die Revision. Leipzig. John Gunther : Inside Europe. London, 1936.

Werner HaAs : Europa will leben. Berlin, 1936. Professor Hantos: Der Weg zum neuen Mitteleuropa. Berlin, 1933. 


\section{SELECTED BIBLIOGRAPHI}

Konrad Heiden : A History of National Socialism. London, 1934. Adolf Hitler. Zurich, 1936.

ERNST HENRY : Hitler over Europe. New York, 1934.

Adolf Hitler : Mein Kampf. Munich, 1934. Reden des Führers und Reichskanzlers vor dem Reichstag am 7. Marz 1936. Berlin, 1936.

Hoetsch-Bertram : Dokument zur Weltpolitik der Nachkriegszeit, Part 7: Sïdosteuropa und Naher Orient. Berlin, I933.

Graham Hutton : Is it Peace? London, i936.

International Reference Library: Politics and Political Parties in Roumania. London, 1936.

F. Elwyn Jones : Hitler's Drive to the East. London, 1937. Othmar Krainz : Hexenkessel Donauraum. Görlitz, 1936. Dr. Emil Krofta : World Peace and Czechoslovakia. London and Maastricht, 1936. Europe at the Cross-Roads. Prague, 1936.

W. T. Layton and C. Rist: The Economic Situation of Austria. London, 1926.

Professor Dr. Franz vON Liszt : Ein mitteleuropäischer Staatenverband als nächstes Ziel der deutschen auswärtigen Politik. Leipzig, I9I4.

Lucy P. MAIR : The Protection of Minorities. London, 1928. T. G. Masaryk: Die Weltrevolution. Berlin, I925.

Col. Emanuel Moravec: The Strategic Importance of Czechoslovakia for Western Europe. Prague, I936.

Edgar Mowrer : Germany Puts the Clock Back. London, I933.

Munin : Oesterreich nach dem Kriege. Jena, I9I 5.

Rudolf NAdOLny : Germanisierung oder Slavisierung. Berlin. E. Noel-Buxton and C. Leese : Balkan Problems and the European Peace. London, I9I9.

Hermann Oncken: Das alte und das neue Mitteleuropa. Gotha, I9I7.

Jaroslav PapoušEK: Czechoslovakia, Soviet Russia and Germany. Prague, 1936.

L. Pasvolsky : Economic Nationalism of the Daubian States. Washington, 1928.

Georg Sahwarzenberger: The League of Nations and World Order. London, I936. 


\section{SELECTED BIBLIOGRAPH}

R. W. Seton-Watson : German, Slav, and Magyar. London, 1916.

Wickham S'TEED : Hitler: Whence and Whither? London, 1934. Vital Peace. London, 1936.

James Turner : Hitler and the Eimpire. London, 1936. Hermann Ullman: Die Bestimmung der Deutschen in Mitteleuropa. Jena, 19I5.

Begumil Vosnak: A Dying Empire. London, igi 8.

Giselher Wirsing : Zueischeneuropa und die deutsche Zukunft. Jena, I 93 I.

Asen ZlatarefF : Dictature ou Démocratie. Sofia, 1936. 
Hurst \& Blackett

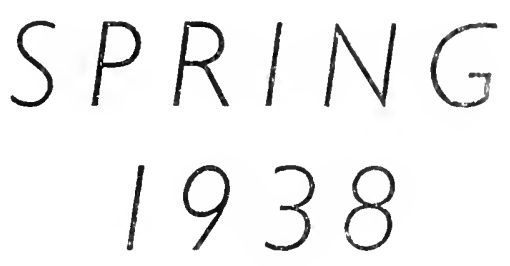

e

Authors who send their work to us can rest assured that their MSS. will be considered carefully and with sympathy and that they will be returned promptly and in good condition

Publishers since 1812

34 Paternoster Row

London, E.C.4 


\section{CONTENTS}

BIOGRAPHY, MEMOIRS, ADVENTURE . 3 SEA LITERATURE . . . . . . 15 E. KEBLE CHATTERTON'S GREAT SEA STORIES . . . . . . . 19 BOOKS ON THE HORSE . . . . 2 GENERAL BOOKS. . . . . . . 22 STANDARD WORKS . . . . . 28 PATERNOSTER LIBRARY . . . . 32 JANUS LIBRARY . . . . . . 34 FICTION . . . . . . . . 35 CHEAP EDITIONS OF POPULAR FICTION 54 TOUCAN POCKET NOVELS . . . 62 WELCOME LIBRARY . . . . . . 63

- These Lists will be sent regularly upon application to the Publishers

- The prices shown in the following pages are in some cases necessarily approximate

- Hurst \& Blackett, Ltd.

Telegraphic Address: LITERARIUS, CENT, LONDON Telephones: CITY 3200 (6 lines) 


\section{HURST \& BLACKETT, LTD. LONDON}

\section{Spring Announcements}

\section{- A RECOMMENDATION OF THE BOOK SOCIETY}

\section{MEMOIRS}

\section{H.R.H. Prince Christopher of Greece}

(Prince Christopher of Greece is the son of the late King George of Greece and the late Queen Olga. The present King of Greece is his nephew.)

Prince Christopher's story is one of vivid human interest, for it covers experiences gained from every side of life.

He has known the splendour of the greatest courts in Europe, and he has known poverty and exile. He has lived through the terrors of revolution, shared in the rejoicings of a restored monarchy. Musicians, knowing him as a brilliant pianist, have welcomed him as one of themselves. He is as much at home In the Bohemian gatherings of Chelsea and the Quartier Latin as he is at Buckingham Palace.

In these pages we get many interesting glimpses of King Edward VII and Queen Alexandra, King George $V$ and Queen Mary, the Czar and Czarina of Russia, Queen Ena of Spain, King Edward VIII, King Manuel of Portugal, Queen Marie of Roumania, King Carol and Princess Helen of Roumania, the Kaiser, the Duke and Duchess of Kent, King Constantine of Greece, Venizelos and Sir Basil Zaharoff, and many others.

On his visits to New York his democracy had delighted the Americans. Standing as he does so close to the Greek throne he is known to hundreds of people who met him in the States as "Mr. Christopher" who married Mrs. W. B. Leeds. 


\section{- Spy tales by a specialist in the art}

He tells of their romance in this story, for despite the verdict of the world it was a true romance in which money played no part. He writes with equal frankness of the splendid years before the Great War, when Kings sat securely on their thrones, and of his lean years in exile. He has always been a student and an observer of life. He tells of it now as he has seen it.

Demy 8 ro.

22 Illustrations.

12s. 6d. net

\section{UNDERGROUND DIPLOMACY Colonel Victor $\mathbf{K}$. Kaledin}

Author of "High Treason", etc.

As an authentic writer upon Intelligence and Secret Service work, Colonel Victor K. Kaledin has made a sreadily growing reputation for himself. In his previously published books, "F-I-a-s-h D.I3", "K.14-O.M.66", and "High Treason", he dealt with espionage, counter-espionage, and the underground workings of the political and diplomatic worlds in pre-war and war-time Russia from the standpoint of a member of the old Imperial Russian Intelligence Service. In his latest work, "Underground Diplomacy", however, Colonel Kaledin breaks fresh ground and considerably extends the field of his writings. With his unique narrative ability and wealth of excitement and colour, he now gives his post-war experiences all over Europe as a private spy -after the Russia of the Romanoffs had passed into limbo and he was, to all intents and purposes. a man without a country.

Following the sinister appearance of Soviet Russia on the stage of the European scene, Colonel Kaledin worked for the Allied Bureau, the Anti-Bolshevist section, directing the Armed intervention of 1918-22. In these pages he tells of his work in connection with the spreading of seditious literature among the Allied troops in Constantinople ; his search in Sofia for the link between the Macedonian Revolutionary Organization and the Third International ; his discovery of the key man who 


\section{- Witty, racy life of a great personality}

served General Lüttwitz in the Kapp Putsch as a Bolshevist agent provocateur; while finally, in the way of activities still further afield, Colonel Kaledin executed several secret missions for Benito Mussolini in the earlier days of the Italian leader's career.

("K.14-0.M.66" is now included in the Paternoster Library, price 3s. 6d.)

Demy 8 ro.

About 15s, net

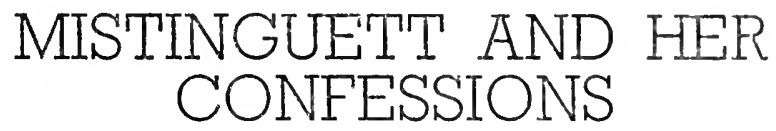

Translated and edited by

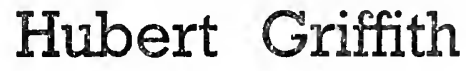

As the idol of the Paris music-hall, Mistinguett has had a glitteringly successful career in the course of which she has had the most entertaining encounters with many prominent figures in English and Continental life, and there can be no doubt that her proverbial joie de vivre comes out to the full in this fascinating book. Mistinguett's infectious gaiety pervades the book, in which, by the way, she has many interesting things to say about Maurice Chevalier.

Mistinguett passes in review the most outstanding of her suitors and their diverse and entertaining methods of approach. They number an Indian Rajah, an American "Hot-Gospeller". to say nothing of relatives of European royal houses. Sandwiched between these revelations are droll stories about American "drummers" who surrounded her in New York with requests for the use of her name in their advertisements, and the platonic courtship of a Confucian Chinese.

Here, in an extremely intriguing volume, are many facts of the great star's life, fresh to the public on this side of the Channel.

Large Demy 8vo.

Illustrated.

About 18s. net 


\section{- Autobiography of a famous variety artist}

\section{LIMELIGHT \\ George Mozart}

Delightful reminiscences of the famous music-hall star, in which he tells, with charm and verve, many stories of his life on the "boards", and many anecdotes of the famous people he has met during his long and varied career.

He has travelled extensively; Australia, America, and Canada were his happy hunting-grounds, and his knowledge of the "Halls" and variety theatres of twenty, thirty, and forty years ago must be almost unrivalled.

He tells several very amusing stories of encounters with royalty, in particular of his early youth, when he was a drummerboy in the Prince of Wales Own Norfolk Artillery Band, which used to play at Sandringham when Edward VII was Prince of Wales and Honorary Colonel of George's regiment.

Anyone who remembers the music-halls of thirty or more years ago would put George Mozart among the first half-dozen turns, and there can be but few people of importance in the stage world that he has not met and about whom he has not a characteristic yarn to tell.

From Arthur Lloyd, Daddy Wright and his sons, Huntley, Fred and Bert, Sir Oswald Stoll, Lottie Collins, Dan Leno, George Robey, Albert Chevalier, Gus Elen, Vesta Tilley, Fred Emney, George Graves, Eugene Stratton, and many others to Bernard Shaw, the Duke of Windsor, Sir Henry Irving, Sir Herbert Beerbohm Tree, and Sir Harry Lauder, this inveterate story-teller conjures up pictures of personalities comic, personalities brilliant, grave and gay, some of whom have gone, some of whom are still with us.

The book is a veritable National Gallery of portraits by the same kindly word-cartoonist, and, once started, one wanders, almost spellbound from picture to picture until the end is come, too soon. . . . 
- Delightful stories of holidays in the sun and snow

\section{ESCAPE ON SKIS \\ Brian Meredith}

Foreword by Rt. Hon. L. S. Amery, P.C., M.P.

\section{RECOMMENDATION OF THE BOOK SOCIETY}

This book is something unique and refreshing in travel literature ; it is a casual and informal account of skiing in the hinterlands of the Canadian Rockies, and of crossing a large part of the Swiss Alps on skis, bringing an entirely new type of book before the general reader.

The author enjoys his skiing as passionately as others enjoy fishing or sailing or travel by more conventional means, and yet he does not take it too seriously or technically. He paints unforgettable pictures of some of the glorious scenery of the world, and infects the reader with his own delight in the sport. re-creating through the printed word the breathless thrills of ski-runs down snowy slopes, escapes from thundering avalanches, and the swish-swish of the skis on the powdery snow on some trek through the massive Canadian forests.

A Canadian who has written extensively on skiing in American and Canadian magazines, and was co-editor of the Canadian Ski Year Book for three years, he knows his subject, and gives a multitude of hints couched in everyday language which fit into the story as it goes along and which are invaluable to the beginner or even to the practised skier.

This book cannot fail to bring pleasure to all lovers of travel, Switzerland, Canada, or skiing, quite apart from all those who just like a good book, and it is dramatically and beautifully illustrated with full-page photographs, which alone make it unique. A portion of one of these is reproduced on the back cover of this List, and can be regarded as a sample of the lovely pictures in the book.

Demy 8vo.

32 photogrophs.

12s. 6d. net 
- Sparkling, scintillating book which mirrors us all!

\section{UNDERSTANDING THE ENGLISH \\ James Howard Wellard}

james Howard Wellard was born an Englishman, but for some sixteen years has been in the United States, latterly on a Chicago weekly paper. Thus he has the unusual faculty of being enough of an Englishman to know what it is like to be one, and enough of an American already to be able to see us from the outside.

It is a study, and a careful study, despite its wit and the brilliant epigrams which scintillate on almost every page, of a race which, though apparently stodgy and without imagination, has managed very nearly to dominate the earth. It probes and searches to find out whether the abundant criticism levelled at the Englishman is justified, as to which specific points of criticism are just and proved; and as to how that which is proved tallies with the Englishman's achievements.

A large part of the book's unusual charm lies in the fact that he says things about us that only an Englishman would know or notice, and yet his criticism does not annoy us as many of the digs would do if they had been penned by one of us ; neither do they offend us as being rudeness or impertinence from a foreigner; he is in the enviable position of being neither one nor the other.

This has the sparkle and nip of champagne with the depth and wisdom of old port ; it is a vintage book which no intelligent person should miss. It makes one laugh, it makes one ponder, but not for an instant can one's attention be diverted from the continual excitement of its pages.

".. it will do a darned sight more than any "hands-acrossthe-sea Society' to promote understanding between the two continents. A wise and witty book-skifful, neatly humorous."-R. L. DUFFUS.

Illustrated with four full-page and thirtytwo other line drawings by WOOD.

Demy 8vo.

10s. 6d. net 


\section{- A brilliant forecast and a grim warning !}

\section{GERMANY PUSHES SOUTH-EAST \\ Dr. Gerhard Schacher,}

(who is a Doctor of Law and Doctor of Economics of German Universities, and correspondent in Prague for "The Economist", the "Financial News" and the "Manchester Guardian Commercial").

Dr. Gerhard Schacher is well known as the author of "Central Europe and the Western World" and other books in which, as well as by his articles in prominent British and American journals, he writes on Central European problems, pointing out their great importance in international relations; emphasizing that they have so often provided the spark igniting a greater conflagration.

He puts this book before the reader just at the very moment when that spark may be struck from the tinder of Danubian politics. Having long observed Germany's insidious influence penetrating the countries of South-Eastern Europe, and having a first-hand and intimate knowledge of the means and methods she uses to gain her influence, there could be no one better qualified to put a clear picture of the Central European situation before the public.

The book is not a mere journalist's report, though the author has a special knowledge of all the important personalities in this part of Europe ; it grips the reader because the author's statements and predictions are startling and yet at the same time bear the stamp of truth and sound reasoning. It is a warning, brilliantly delivered, by a man who is a specialist in his subject, of the menace of Nazism not only to Central Europe, but to the peace of the world.

".. He has succeeded in giving us a large amount of valuable information on German aims and methoj's ; and above all, there are a number of pages which reveal an extremely keen political observation. The passages on Italy's essential conflict of interest with Germany in the Danube basin are first class." -C. A. MACARTNEY in "The Spectator."

Large Crown 8vo.

7s. 6d. net 
- Journalist's reminiscences, with a new angle

\section{RESTLESS QUEST \\ Jerome Willis \\ Author of "The Last Adventurers", etc.}

This book is a record of the author's travels and mental experiences, beginning with that of an airman with Deniken's army in the Russian Revolution of 1919 and ending with that of a war correspondent during the siege of Madrid in 1937. If it has a definite pattern it is that of the mental attitude towards life of post-war youth, those young people, who, like the author, found it difficult to settle down to anything after entering the Service, straight from school, and returning to civilian life, feeling a man, but yet a youth. This queer restless spirit carried him into the jungles of Central Africa as a trader; through a political campaign in London and out to Singapore as a journalist. Always it has a certain ironic humour behind the snapshots of various parts of the world. From 'covering' the waterfront" in Singapore, through the Philippines, China, and Japan, with sketches of Hollywood and the stars, Chicago and New York en route, he came back to London to join a world-famous news-agency, and ultimately found his way into shell-torn Madrid.

Demy 8 vo.

About 10s. 6d. net

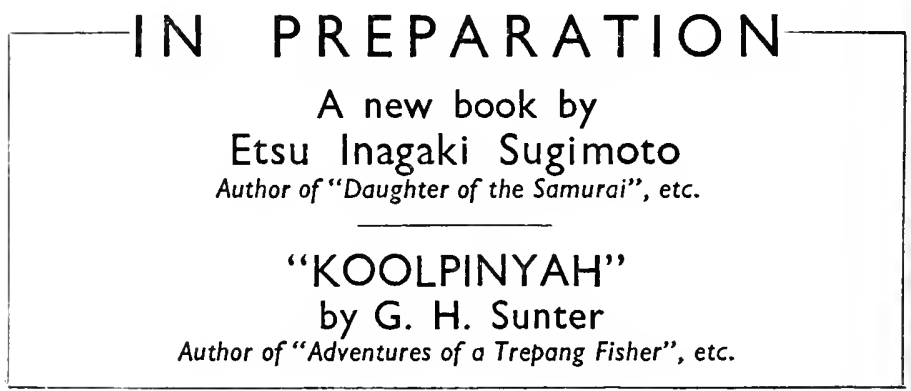


-The life-story of the year!

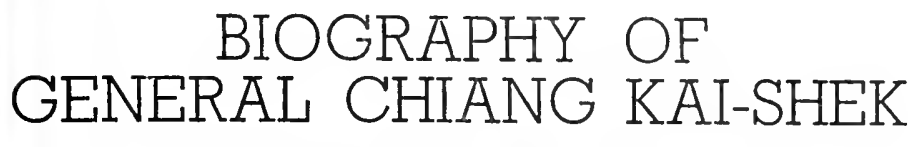

\section{Hollington $\mathrm{K}$. Tong}

It has become clear that a book about General Chiang Kai-shek, now leading China in her valiant struggle against a rapacious enemy, is becoming more and more necessary so that the people of this country can obtain a correct estimate of the man who is China's Prime Minister. We read about the Prime Minister's actions and speeches in the newspapers, but of the man, his upbringing and character, we know almost nothing. This state of affairs is remedied in this fine, accurate study. In the words of the author's preface :

"Recent events in China have proved Generalissimo Chiang Kai-shek to be the greatest soldier-statesman of our time on the Continent of Asia. By general admission, China, under his leadership, has progressed more in the last ten years than in any previous century.

In these two volumes is related the life-story of the Builder of Modern China, who has successfully evolved order out of chaos, having welded discordant elements into an effective national unit, and won respect for his country from without. They describe his childhood and his early youth-the days when he was mischievous, fearless, combative and full of determination.

They record twenty years of intensive preparation for the important role which he is playing to-day. His tenacity of purpose in adhering to the revolutionary cause which at times appeared hopeless, and his unwearying loyalty to the late Kuomintang leader, Dr. Sun-Yat-Sen, which was shown during this preparatory period, are as graphically told as circumstances warrant. After remaining in comparative obscurity for one-third of his lifetime, he emerged triumphantly as President of the Whampoa Military Academy, and as Commander-in-Chief of the Northern Punitive Expedition. His life-story from this time became the story of China." 
This story, which takes us through the early Japanese troubles, up to 1937, is told with power and vividness in this convincing well-documented and sincere book, which is certain to become the foremost authority on this remarkable man and his times for many years to come.

The author, a Chinese, who was a schoolfellow of Chiang Kai-shek, quotes freely from official files and documents to which no other biographer would have had access; he has known the General from his youth, has seen him before and after his striking rise to the high position he holds to-day. No one could be better qualified to give us a portrait of the man to whom the whole world looks for the regeneration of a nation comprising one-fifth of the world's population.

2 Vols. Large Demy $\left(9^{\prime \prime} \times 6-1 / 8^{\prime \prime}\right)$. Illustrated. 30s. per set

\section{- The War-from a "regular's" point of view}

\section{A TROOPER IN THE "TINS"}

THE AUTOBIOGRAPHY OF A LIFEGUARDSMAN

\section{R. A. Lloyd}

How many of the thousands of spectators who from day to day admire the glossy black horses, alert and beautiful in their movements, and the magnificent physique, gleaming breastplates, and waving plumes of the Life Guards as they ride from Knightsbridge to the Horse Guards, realize that these "tin soldiers" are, before all else, highly trained troops ready to take their place in war at a moment's notice ? A full regiment of Household Cavalry formed part of the first Expeditionary Force in 1914, shed its "glad-rags", and gave a good account of itself on the Retreat from Mons. Six weeks later, at the beginning of October, three more regiments of Household Cavalry landed at Zeebrugge and Ostend with the 7th Division, and played a vital part in the first battle of Ypres.

The author served in the ranks of the First Life Guards for ten 
years (1911-1921). He gives an intimate first-hand account of the life and work of a Household Cavalryman in London and Windsor during the three years 1911-1914. He describes the preparation and departure of the first regiment to Mons. $\mathrm{He}$ is left behind with a few others to help form and equip the new second unit. There are lively scenes before the First Life Guards, now part of the new 3rd Cavalry Division, disembark at Zeebrugge on October 8th. The retreat from Antwerp is followed by weeks of hard work and fighting round Ypres.

The drab monotony of billets, the futile spells of cavalry training in preparation for something which never happened, and the heartbreaking return afterwards to the soul-killing occupation of maid-of-all-work in and around the line-all these would have taken the heart out of any other set of men. The fine spirit of comradeship and the never-failing sense of humour of the British soldier alone render the continuation of this state of affairs possible. Finally, early in 1918, the regiment parts with its horses and becomes a machine-gun battalion. Scarcely is the new battalion formed and equipped when it is decimated in an air-raid on May 19th, 1918. The author is badly wounded in this raid and spends the next two years in hospital. He describes his hospital experiences in and around London, and finding that the post-war army holds no prospects, he takes his discharge and returns to schoolmastering.

This is the first book we know of which presents fully and sympathetically the regular soldiers' part in the great struggle ; this is essentially the story of the men to whom the privations and perils of those four dreadful years were but part of the job they had been trained for.

Throughout the story the author has avoided picturing the hideous side of war with its blood and filth. This side must be only too obvious to anybody who gives the subject of war a moment's thought. The less-obvious side, comprising the cheerful, great-hearted spirit in which the troops carried on under such conditions, is apt to be neglected and forgotten. The author has, therefore, tried to recall the brighter moments of his experiences, and to give some idea of the mentality of the men whose comradeship he was privileged to share, and whose loyalty and humanity made every moment of the war worth living.

Demy 8 ro.

Illustrated.

About 12s. 6d. net 
- New additions to the ever popular Paternoster Library

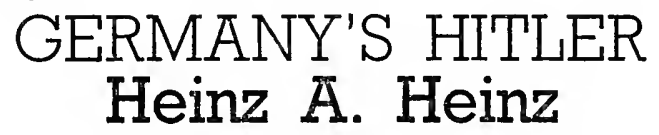

(Volume XIV in the Paternoste: Library)

In this book Herr Heinz's aim has been to draw a picture of the Führer from details supplied at first hand by those friends and helpers and comrades of his who believed in him from the first, who joined him at the beginning, stood by him through the darkest days, and have lived to see the Germany of today which is his creation. None of those people were out for themselves - most of them remain in poor and humble stations today; they, like their leader, had but a single eye, for the lifting up of the Fatherland.

Herr Heinz has written a book half-way between biography and history. It is non-controversial, but excellently well informed, lively, convincing, and exceptionally interesting. It has been brought right up to date for this edition, and new matter has been incorporated.

"The book is full of interest, and deserves to be read. The story of Hitler's career is one that vies with the romances of imaginative fiction." - - rish Independent.

"There is a fine balance about the book which makes it equally attractive to the serious historian and to the ordinary reader." - Sunday Mercury.

"Heinz A. Heinz's book will be as absorbing as the best novel." -Liverpool Post.

Demy 8vo.

3s. $6 d$. net

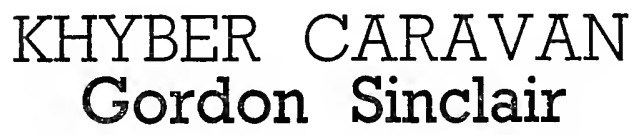

(Volume XV in the Paternoster Library)

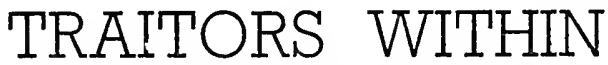

Ex-Detective Inspector

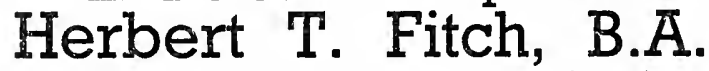

(Volume XVI in the Paternoster Library)

(For full list of titles in the Paternoster Library see page 33.) 


\section{SEA LITERATURE}

- Two cheap editions of famous sea yarns

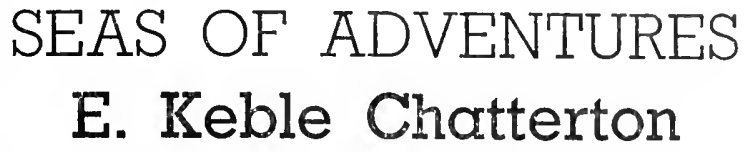

"It constitutes a valuable piece of historical writing. . . . Although I spent two years of the Great War in the Mediterranean, and although I have contributed materially to the literature on the subject, I learnt much from his book and read it with unflagging interest.

"... It is cer tain that the pages of this book will be read with deep interest by many, and that the book itself will be indispensible in every library that deals with the war at sea." Vice-Admiral C. V. Usborne in the Sunday Times.

\section{VALIANT SAILORMEN E. Keble Chatterton}

"Written with the usual wealth of detail for which Mr. Chatterton is so well known, "Valiant Sailormen" covers a period of seventy years and describes many of the great sea adventures of that time. It is certainly a wonderful record of stirring deeds, brave seamen, and famous ships. A nautical document that will be read and enjoyed. It should certainly be added to all historical libraries." - The Seogoer.

Demy 8vo.

Illustrated.

3s. 6d. net eoch 


\section{- A thrilling, dramatic true story of the sea!}

\section{"SEVERN". SAGA \\ E. Keble Chatterton}

Author of "Valiant Sailormen", etc.

This is the thrilling career of H.M.S. Severn, one of the most unusual warships ever built, which nevertheless during the period 1914-18 made more naval history than perhaps any vessel of her size.

Originally built as a monitor for the Brazilian Navy, she was just ready when the Great War broke out, and this exciting true yarn begins with August 1914, when British naval officers went to take her over from the builders.

The Admiralty sent Severn across to bombard the German armies in Belgium, and her narrow escapes from U-boats make stirring reading. When the projected German invasion of England was to have taken place, she went to the Wash in readiness to resist the enemy's landing. What happened, and why they did not come, is here dramatically revealed.

We next find her being sent to the Mediterranean, where she was to take part in the Dardanelles campaign, but the East African crisis demanded her presence at the Zanzibar base. How they managed to tow Severn from Malta, through the Suez Canal, and down the Red Sea, in spite of amazing difficulties, is here fully told for the first time.

Then came her famous exploits when she floated up the River Rufiji through the swamps to undertake two terrible duels with the German cruiser Königsberg. For this incident only three brief chapters out of twenty-five could be devoted in Mr. Chatterton's "'Königsberg' Adventure" (now in its 9th thousand). But now at last the full and complete authentic account is presented with a richness of detail rarely available.

From the Severn's surviving Commanding Officer (now a distingulshed Admiral), the signalman on the bridge, and from others ; from diaries and a mass of original unpublished documents; from German sources and the German signalmen aboard Königsberg, the author has been privileged to narrate 


\section{- A yachting book to remind you of the sun!}

the story with such fullness and exciting suspense that it must for all time remain a unique volume.

We follow her attacking Tanga, destroying the German liner lying there; later capturing Bagemoyo and hoisting the Union Jack ; being present at the surrender of Dar-es-Salaam : and in fact leading a hectic life off the African coast till 1918.

Back she comes to the Mediterranean, and begins a new series of voyages; up the Aegean and Dardanelles to Constantinople at Armistice time; then into the Black Sea, spending some months during 1919 up the Danube, emerging from that river when the ice cleared; finally coming home to England, after these adventurous years, to be broken up.

Altogether a remarkable record of surprises, narrow escapes, comedies, and tragedies. A book for the general reader who enjoys a first-class gripping yarn ; but also a volume of permanent historical value to be in every library.

A special feature of the book is the remarkable illustrations. Large Demy 8 ro.

Illustrated.

18s. net

- "Mr. Keble Chatterton has developed into one of the most delightful yachting chroniclers. The book has all the charm of the best kind of walking-tour book, with the sailing, as it were, thrown in."-Daily Telegraph
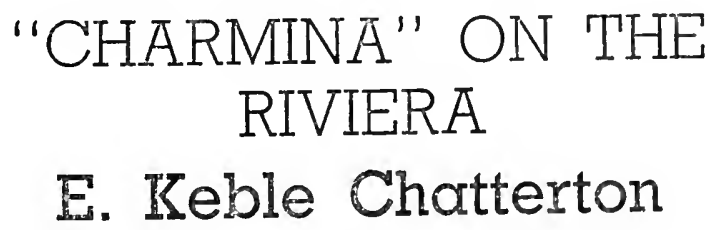

Here is a travel book quite out of the ordinary.

With envy, the reader will vicariously cruise from Toulon to Italian waters under a deep-blue sky, sailing through cobalt Mediterranean seas into picturesque havens past scenery rich with colouring and brilliant with sunshine. This is the kind of book that makes you long to sell your car, give up everything. 


\section{-The indispensable "THE YACHTSMAN'S PILOT"}

and go away south on the best kind of pleasure voyaging ; and even those who know something of the Riviera from the land will find its revelation from seaward something much more fascinating.

Not only is " 'Charmina' on the Riviera" a book for yachtsmen, but for every man, woman, and child who revels in sunshine and travel. The 35 illustrations make this beautiful volume additionally attractive.

"There are in its pages the glow and the glitter of blue seas, the scent of olives and lemons, the idyllic pleasantness of a magic coast. . . . Mr. Chatterton displays here a gift of making every little trifle of interest." -Blue Peter.

"A travel book quite out of the ordinary."-Yochting Monthly. "The whole book has an entrancing quality."-Scotsmon.

"Mr. Keble Chatterton excels at description." - Yachtsmon. Demy 8 vo.

Illustrated.

12s. 6d. net

- "Has established itself firmly... one can imagine no better guide."-Lloyd's List

\section{E. Keble Chatterton's}

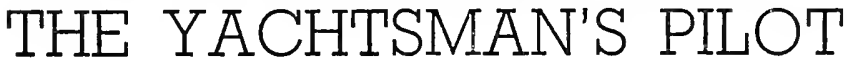

To the harbours of England, Scotland, Ireland ; the Continent of Europe from Ymuiden to Bordeaux; Bordeaux to Sète by Inland Waters; and the Mediterranean Harbours from Sète to Toulon ; the Riviera Harbours to the Gulf of Genoa ; with notes on the Italian Harbours from Genoa to Naples. "A most comprehensive and accurate book." - Field.

"Worthy of a place in every cruising yachtsman's bookshelf." Motor Boot.

Demy 8vo. Third revised and again Enlarged Edition. With 52 large-scale plans and particulars of more than 800 harbours and anchorages. 


\section{Cheap Editions of E. Keble Chatterton's SEA

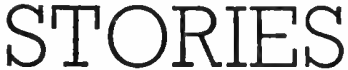

- "Mr. Keble Chatterton has made a place and reputation all his own." - Illustrated London News Demy 8 vo. Illustrated.

Each 3s. 6d. net

\section{THE SEA RAIDERS (12th thousand)}

"Absolutely authentic; as thrilling and incredible as anything written by Henty or Captain Marryat." -Evening Stondord.

\section{GALLANT GENTLEMEN (12th thousand)}

"Here, in these records of duels to death, of courage and cunning and the final rage of battle, there is the essential spirit of epic." -Sunday Times.

\section{THE "KÖNIGSBERG" ADVENTURE}

(9th thousand)

"A true mystery thriller of the sea." -Liverpool Post.

"One of the most remarkable naval stories."-Evening Standard.

\section{THE BIG BLOCKADE (9th thousand)} "Full of thrilling stories of the sea."-Daily Mail. "An admirable tribute to an engrossing record." - The Times.

\section{AMAZING ADVENTURE}

\section{A TRUE NAVAL BIOGRAPHY}

(6th thousand)

". . Both thrilling and inspiring. "Amazing Adventure" is amazing in very truth. It bears out again and again what the Morning Post said of Godfrey Herbert, that "no man ever had such narrow escapes'." - Naval Correspondent in the Morning Post.

"Seas of Adventures" and "Valiant Sailormen" are new volumes dealt with on p. 15.) 
- A book which is an encyclopaedia on the care, training, and management of the horse

\section{"TO HORSE !" \\ Captain Frank C. Hitchcock, M.C., F.I.H.}

With a Foreword by COLONEL SIR PERCY LAURIE, K.C.V.O., C.B.E., D.S.O., in which he says :

"I am confident that this latest treatise by Captain Hitchcock will supply a big demand. It is intensely interesting as well as instructive, and it should increase keenness and enthusiasm for everything to do with the horse."

The author of that popular book "Saddle-Up", which is a standard authority on the subject of equitation and stable management, and which is now in its eighth edition, needs no introduction to readers.

In this book Captain Hitchcock continues to write in his entertaining style a thoroughly practical work on the subject of riding, training the horse, with special chapters on the care of the horse and the construction of stables.

Common ailments and diseases are dealt with in order that the horse-owner will know from symptoms what first aid to give while awaiting professional advice.

This very comprehensive volume includes chapters on bitting and saddlery and the preparation of horses for point-to-points. The book should prove invaluable to all horsemen and horseowners, and it should be a boon to those who have the responsibility of teaching equitation and for those candidates preparing for the Institute of the Horse examination for the instructor's certificate. The subjects which are included in the syllabus of this examination are thoroughly dealt with in a most efficient and practical manner.

The book is admirably illustrated with photographs and with the author's own explanatory diagrams to reinforce the text. 


\section{"TO HORSE !"- List of Contents}

1. Points of the horse : the effect of conformation on subsequent training.

11. A survey of the origin and history of the horse through the ages and the evolution of the thoroughbred.

IIIA. Description and identification of horses, pedigrees, breeding, and nomenclature.

14IB. Veterinary certificates and law of warranty. Unsoundness in wind and limb, terms and descriptions. How to tell the age by the teeth.

VA. Stables and stab!e-construction.

IVB. Stable management and routine. Care of the horse. Watering, feeding, quantity and quality, grooming, bedding, exercise, clipping, clothing, bandages, shoeing, care of the teeth, stable vices, care of the horse after hunting.

$V$. The rider's seat and hands. The horse's mouth, riding and leading.

Vl. Advanced riding, the aids, the flexions, the diagonals, jumping, the passage, the half pass.

VII. Training the horse. Longeing, long reining, "tack". Backing the young horse, jumping and training to jump. Stages in horse training. Saddlery required. Jumping fences and schooling over fences. Construction of various types of fences.

VIII. Various styles of riding. Comparison of seats, show, hunting, racing, polo, military, and the advantages and characteristics of the respective seats.

IX. Part I. Saddling and Bridling. Method of saddling, saddle fitting, girths. Stirrup irons. Cleaning of saddlery. The saddle room. Part II. Bitting, Bits, "Mouthing". Martingales : various types and nosebands. Curbs and adjustment.

$X$. Instructing in equitation. Difficulties met with. Riding-school advice to instructors. Value of instructor's demonstration horse. Syllabus of I. of $\mathrm{H}$. examination. Type of Questlons. Prozramme of work.

XI. First Aid.-Common ailments and diseases. Symptoms, causes, and treatment whilst awaiting professional advice. Method of administering physics, etc.

Appendices. - Colours and markings by permission of the Royal Veterinary College, etc. 


\section{RECENT IMPORTANT GENERAL BOOKS}

- "This is the best life of Keats that has been written so far."-Adelphi

\section{ADONAIS-a new Life of Keats Dorothy Hewlett}

Robert Lynd in the News Chronicle: "There has" hitherto been no entirely satisfactory Life of Keats for the general reader. . . . Miss Hewlett has written a full-length biography of Keats which for the first time incorporates in a highly interesting form all that has come to be known about him and his world till our own day."

Demy 8vo.

Illustrated.

15s. net

- "This is a work of genius."-J. S. Collis in the Observer

\section{FOR DEAR LIFE Belinda Jelliffe}

“. . . Her remarkable autobiography makes an extraordinary narrative! A life-story related so fearlessly that it becomes far more exciting and absorbing than a whole library of novels." - Richard King in The Tatler.

"It is a remarkable life-inspiring. It might not read inspiringly. It might be dull. Yet it has not one dull line. This is the artistry we don't meet with twice a year.

The pace, the understatement, the engraving of this work make it attain to the condition of sculpture. Touching this book, we touch not one but many. Further, we leap into the centre of life again ; and again we see it as it is-and we do not despair. In short, this book is too fine a thing to be the shooting star of a publishing season. But it will be there next year, and the next, glittering like Jupiter for all who have eyes to see."-J. S. Collis in the Observer.

Demy 8vo.

10s. 6d. net 


\section{RECENT GENERAL BOOKS}

- Four absorbing travel books

\section{MY RUSSIAN JAILERS IN CHINA}

\section{Georg Vasel}

Translated by Gerald Griffin

"The author's narrative provides a remarkab!e exposure of the methods used by Russia to establish her influence in Chinese Central Asia." - Times Literary Supplement.

Large Demy 8 vo.

Illustrated.

18s. net

\section{THE LAND THAT TIME FORGOT Michael Leahy}

"It is an exciting book, well worth reading. There are enough thrills in its pages to keep any reader fast in his chair long after his normal bedtime."-lllustrated Sporting \& Dramatic.

Demy 8vo. Illustrated.

12s. 6d. net

\section{STRANGE TO RELATE Thorburn Muirhead Author of "Without Prejudice"}

"This is a delightful book; and with such a fund of knowledge of the world, and so pleasant a manner in imparting it, it is to be hoped that Mr. Muirhead will write others." Times Literary Supplement. Demy 8vo.

Illustrated.

12s. 6d. net

\section{ADVENTURES OF A TREPANG FISHER}

\section{George H. Sunter}

Author of "Buffalo-Shooting", "Fog", etc.

"Mr. Sunter has many thrilling stories of his black crew, his Japanese rivals, not to forget the sharks and crocodiles and his review of native customs with vivid accounts of their observance."-Public Opinion.

Demy 8vo.

Illustrated.

12s. 6d. net 


\section{RECENT GENERAL BOOKS (contd.)}

- "If you love dogs you should get this bookyou'll enjoy every line of it."-Edward Wood in Picture Show

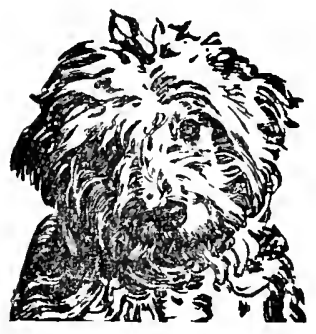

\section{SCRUFFY \\ Cloude Burbidge}

"This mongrel has a sly humour, the urchin's shrewd perception, and the Cockney's wit. Those who love a dog will chuckle at his reactions and viewpoint-and they may learn something about training a dog's intelligence too." -Daily Mail.

"Every person who likes animals can look forward to a very enjoyable time while reading "Scruffy". . . ."-Captain E. A. V. Stanley in the Greyhound Express.

"The book is one of the most readable that I have perused for many a day with a dog as its theme."-Dog World.

"For a dog who says he can't spell properly, Scruffy has a fine style of writing." -Daily Mirror.

Demy 8vo. Illustrated. 7th Thousand. 5s. net

\section{POEMS}

\section{PERSEPHONE IN WINTER Robin Hyde}

"Both the language and the rhythm of her verse are at once natural and original. Equally original is the range of her subject-matter and the way in which she makes it her own. .... She can delicately evoke the atmosphere of places ... her poems have a rare imaginative intensity." - The Times. Crown 8 vo. 


\section{Standard Books}

on the

\section{HORSE AND RIDING}

"SADDLE-UP"

\section{Capt. F. C. Hitchcock, M.C.}

A Guide to Equitation and Stable Management, including Hints to Instructors.

With a Foreword by SIR FREDERICK HOBDAY, C.M.G., F.R.C.V.S., F.R.S.E.

"A highly practical work from the pen of one who knows his subject. The book is an education in equitation and horsemastership."-lrish Field.

"Captain Hitchcock has written and illustrated a book ... which will be accepted immediately as a standard authority on this subject."--Robin Goodfellow, Daily Mail.

8th Impression. With 120 Illustrotions. Demy 8vo. 10s. 6d. net

\section{THE FORWARD SEAT \\ Captain V. S. Littauer}

Modern Horsemanship for Beginners

"To novice riders it is particularly well suited, and I recommend it without hesitation. I regard this book as an outstanding book of its kind, in both matter and manner."-Horse and Hound.

Crown 8vo.

Illustrated.

6s. net

\section{MODERN POLO}

\section{Lt.-Col. E. D. MILLER, C.B.E., D.S.O.}

A comprehensive account of the theory, development, and practice of the game.

"Both in the matter of polo-playing and in that of choosing and breeding polo ponies, the volume is a certain authority."

- The Times.

6th Edition, largely rewritten and revised. With 150 Illustrations. Demy 8vo. 


\section{Standard Books on the Horse and Riding}

\section{BREAKING AND RIDING James Fillis}

With Military Commentaries. Translated by CAPT. M. H. HAYES, F.R.C.V.S.

Mr. Fillis is acknowledged throughout Europe as the greatest rider of his time, and the rulers of most of the European countries have accorded him special marks of their appreciation of his unrivalled ability.

"Those who are anxious to know something more about horsemanship than is implied in mere sticking on would be well advised to study Mr. Fillis's pages. A higher authority there could not be."-Field.

5th New Edition.

With 70 Illustrations.

18s. net

\section{HORSE FACTS}

\section{Major A. J. R. Lamb, D.S.O.}

A Brief Study of the Points of the Horse and Equine Mechanism

"Just over a hundred pages of very well-arranged, very wellillustrated, and very interesting matter."--Horse.

"Might almost be termed a horse dictionary."-Cavalry Journal.

Second Edition. Demy 8vo. Illustrated. 8s. 6d. net

\section{RIDING AND SCHOOLING HORSES \\ Lt.-Col. Harry D. Chamberlin}

Practical Advice on Horsemanship for the Expert and the

Novice, with a Special Chapter on Jumping

With an Introduction by the HON. JOHN CUDAHY

In this book are set forth the Principles of Equitation as laid down by famous cavalry schools. Its chief object is to help the horseman of much or little experience.

Demy 8 vo.

With 52 Half-Tone Illustrations.

10s. 6d. net 
Standard Books on the Horse and Riding

\section{Five Important Books by \\ CAPT. M. HORACE HAYES, F.R.C.V.S.}

\section{POINTS OF THE HORSE}

A Treatise on the Conformation, Movements, Breeds, and Evolution of the Horse, with 660 illustrations.

"The intrinsic value of the book and the high professional reputation of the author should ensure this new edition a cordial welcome from sportsmen and all lovers of the horse." -The Times.

5th Edition.

Super Royal 8 vo.

42s. net

\section{RIDING AND HUNTING}

"One of a number of works written by Captain Horace Hayes which are deserving of being regarded as standard works. Admirably turned out, brim-full of splendid hints for riders of all descriptions. "-Daily Telegraph. 5th Edition. 258 Illustrations. Demy 8vo. 20s. net

\section{STABLE MANAGEMENT AND EXERCISE}

Revised and enlarged. A book for horse-owners and students.

Illustrated by numerous reproductions of photographs.

"Eminently practical." -Field.

Demy 8vo.

20s. net

\section{VETERINARY NOTES FOR HORSE-OWNERS}

An Illustrated Manual of Horse Medicine and Surgery

"A necessary guide for horse-owners, especially those who are far removed from immediate professional assistance." - The Times.

12th Edition. Revised and enlarged. 276 Illustrations. Demy $8 v 0$ 20s. net

\section{TRAINING AND HORSE MANAGEMENT IN INDIA}

Varieties of food, stable routine, clothing, management on board ship, and all other points of horse management in India are treated in a clear and helpful manner, which will serve as a yery useful guide to all horse-lovers in the East.

7th Edition.

Revised and largely rewritten.

10s. 6d. net 


\section{STANDARD \\ WORKS}

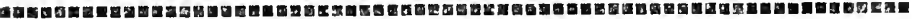

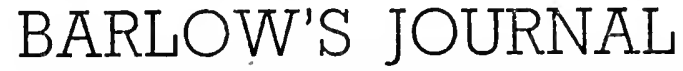

Of his life at sea in King's ships, East and West Indiamen, from 1659-1703

Transcribed from the original manuscript formerly in the possession of Admiral Sir J. S. Yorke, by Basil Lubbock, author of "The China Clippers", "Round the Horn Before the Mast", "The Log of the "Cutty Sark'", etc.

"One of the most fascinating sailors' journals ever written." - Listener.

"Will become a classic."-Manchester Guardian.

in two volumes. Large Demy 8vo. With 8 Coloured Plates and 64 reproductions from Barlow's drawings.

Ist cheap edition.

2 Is. per set

\section{SAILING MODELS-ANCIENT AND MODERN \\ E. Keble Chatterton}

"A triumph of the publisher's art and an invaluable product of the author's painstaking research."-Liverpool Post.

Demy 4to. With 7 Plans and 161 lllustrations in colour and halftone. Limited to 1000 copies.

Ist cheap edition. 2 |s. net

\section{MEMOIRS OF WILLIAM HICKEY, 1749-1809}

Edited by Alfred Spencer

A chronicle of peculiar interest and historical value.

Volume 1. 1749-1775. Demy 8vo. 15s. Ninth Edition II. 1775-1782. Demy 8vo. 15s. Seventh Edition III. 1782-1790. Demy 8vo. 15s. Fourth Edition IV. 1790-1809. Demy 8vo. 21s. Third Edition "For colour and zest these memoirs would be hard to beat, were they fiction they would be called 'unmatchable pictures of the time'."-Manchester Guardian. 


\section{STANDARD WORKS}

\section{LIBEL FOR LAYMEN}

\section{A. Mackinnon and J. Irllan Bell}

With an Introduction by MICHAEL JOSEPH

"An excellent little book. Points out clearly the various pitfalls and snags to be avoided."-Scotsman.

"Will provide the reader with a quick approach to an understanding of the subject." -The Times.

Crown 8vo.

3s. 6d. net

\section{HOW TO WRITE BROADCAST PLAYS Val Gielgud}

A book for those interested in radio drama and in particular for all aspiring radio dramatists. The author has included three plays of his own : "Friday Morning". "Red Tabs", and "Exiles", which he does not hesitate to criticize with regard to method and technique.

Crown 8vo.

25. 6d. net

\section{LEARN TO WRITE FOR BROADCASTING Claude Hulbert}

Foreword and Appendix by John Watt

In this book, by the well-known actor, author, and broadcaster, the technique of writing for the radio is fully explained, especially for those who wish to turn their talents in this remunerative direction.

Crown 8vo.

Is. net

\section{COMMON-SENSE CONTRACT \\ Laurence H. Cade}

"I have never met Mr. Cade. One day I hope I shall, as I should like to congratulate him in person on his excellent contribution to Bridge literature." - Sunday Referee.

Crown 8vo.

2s. net 


\section{STANDARD WORKS}

\section{KITCHENETTE COOKERY Adele Adair}

Two classes of people are usually neglected by writers of cookery books : those whose kitchens will hold only a diminutive oven and those who live in bed-sitting rooms. In each case economy is often a necessity and Miss Adair has written specially for those who live under these conditions. It will be a revelation to most people to see what delightful and attractive dishes can be prepared with the simplest apparatus, and with a minimum of expense.

Crown 8vo.

Is. net

\section{O'CLOCK CAKES AND PASTRIES Frank E. Hall}

(Diploma, International Flour Confectionary Specialist)

Mr. Hall is a demonstrator and lecturer to Master Bakers Associations, and is the holder of numerous diplomas and certificates. Consequently he has all the qualifications for writing a badly needed complete recipe-book for the pastrycook. It is hardly too much to say that no home should be without this delightful collection of tried and proved recipes, which is a most valuable addition to the kitchen library.

Crown 8vo.

Is. net

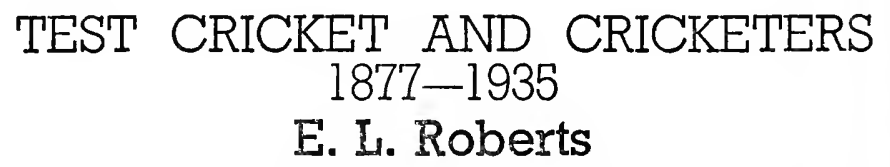

Ralph Ricketts, writing in the London Mercury, says of the book: "An excellent manual of statistics, well illustrated with photographs selected by Mr. P. F. Warner. It should find a place in the libraries of all those who want complete collections of books on cricket."

With 15 photographs of celebrated cricketers, selected by Mr. P. F. Warner.

Crown 8vo. 


\section{STANDARD WORKS}

\section{PRACTICAL CARTOONING FOR PROFIT}

\section{Will Farrow}

"A study of the copious drawings, by different artists, which he reproduces, will teach a great deal about technique; and the aspirant will profit from his remarks about what and how to observe."-The Times.

"He puts his lessons down in a new and very interesting style ; even to a fellow artist the book is full of interest. . . . Altogether it is a book I can thoroughly recommend." - Lance Mattinson in the Daily Herald.

Crown 4to.

Illustrated.

2s. net

\section{SEX AND COMMON SENSE A. Maude Royden}

These much discussed addresses by Miss Maude Royden are, to use her own words, intended "to provoke discussion and engender light". Much of the book, therefore, is of a controversial character, and Miss Royden does not hesitate to attack what she believes to be wrong, whether it is with regard to our laws about marriage, our refusal to let light in on the problems of sex, or the more recent tendency to preach moral anarchy as their sole solution.

Professor J. Arthur Thomson, M.A., LL.D., says : "Every page in the book leaves one better. Everything is illuminated with the light of nobility."

"Never was there greater need for light and clear speaking on matters that have been kept too much in the background. Miss Royden is not afraid to speak plainly; she has the courage to examine, particularly from the woman's point of view, questions on which women too long have been silent." Evening Standard.

Crown 8vo.

(9th edition)

4s. 6d. net

Page Thirty-One 

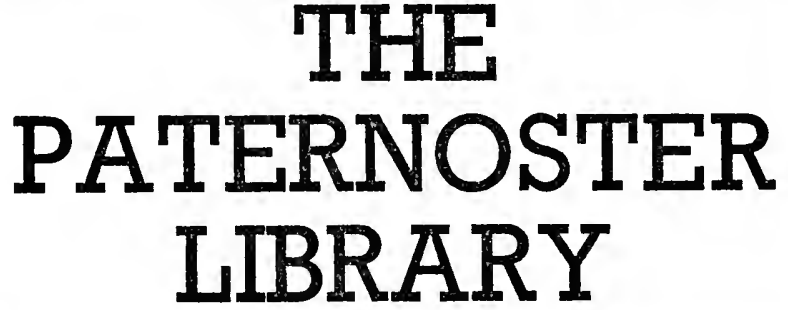

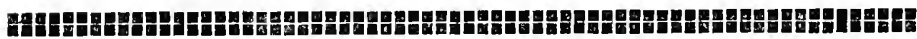

IN UNIFORM FADELESS CLOTH BINDING

DEMY 8vo.

3s. 6d. NET EACH

- Contains in Vols. $V I$ and $X I$ two brilliant books on the Far-East question

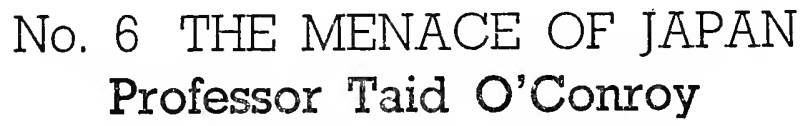

Bernard Shaw said of it : ". . I want you to tell people to read Professor O'Conroy's book. It is a revelation."

\section{No. 11 JAPAN MUST FIGHT BRITAIN Lt.-Comdr. Tota Ishimaru}

This work is a clear logical expose from the pen of an authoritative Japanese author of the Pan-Asia movement to establish Tokyo as the pivot of an Empire 1,000,000,000 people strong. It should be read by every European, for it is an explanation and a forecast of what Japan is doing and intends to do. It clarifies many things which seem a puzzle to the observer of Far-Eastern politics, and it is astonishing in its revelation of the Japanese mind. 


\section{THE PATERNOSTER LIBRARY}

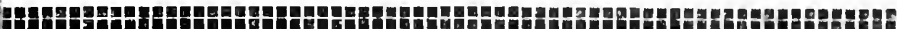

- Other volumes in the series:

VOL. I. A Daughter of the Samurai, by Etsu Inagaki Sugimoto (80,000 copies sold in England and America)

, II. My Struggle (Mein Kampf), by Adolf Hitler (37th Thousand)

" III. The Tudor Wench, by Elswyth Thane (12th Thousand)

"IV. My Autobiography, by Benito Mussolini (52nd Thousand)

V. A Million Miles in Sail, by John Herries McCulloch (9th Thousand)

VII. The Black Tents of Arabia, by Carl R. Raswan (6th Thousand)

VIII. Schiggi-Schiggi : The Adventures of Leo Parcus in the Forests of Bolivia. by Fritz Strauss (5th Thousand)

. IX. The Land of the Lingam, by Arthur Miles (Gervée Baronte) (7th Thousand)

" X. A Daughter of the Narikin, by Etsu Inagaki Sugimoto (6th Thousand)

" XII. The Rose of London, by Guy Paget (6th Thousand)

"XIII. K.I4-O.M.66, by Colonel Victor K. Kaledin (8th Thousand)

" XIV. Germany's Hitler, by Heinz A. Heinz (See p. 14)

Other volumes in preparation (See p. 14)

Page Thirty-Three 


\section{The

Demy 8vo. 3s. 6d. net each.

"To the general reader seeking to build up a library of gaod books at a moderate outlay, Messrs. Hurst and Blackett's 'Janus' Library will be very welcome ; for here he can get a steady supply of interesting literature, originally published in high-priced editions, but re-issued in this attractive form at 3s. 6d. a volume." - The Scotsmon.

\section{THE GALANTY SHOW Arthur Lambton}

"Decidedly worth buying." - Trevor Wignall in the Doily Express.

\section{THE COURT OF KING CHRISTIAN VII OF DENMARK}

P. Nors (Edited by E. Steen)

"Mr. Nors has written something better than a book of scandal in this study of a modern Nero and his Court." -Daily News.

\section{ROBERT LOUIS STEVENSON AT DAVOS W. G. Lockett}

"An exceedingly attractive and carefully written volume ... a valuable contribution to Stevensonian biography ... will make a strong appeal to lovers of 'Tusitala' all over the world." - The Scotsmon.

\section{CERVANTES AND THE MAGICIANS \\ Roger Boutet de Monvel}

"The success of a partially imaginative biography (translated by A. William Ellis) depends on the author's appreciative realization of the central character. This process has been thoroughly achieved by M. de Monvel." -The Scotsman.

\section{A WOMAN'S SOUL \\ Lady Catherine Milnes Gaskell}

"It is the real thing that interests this plasant author, the real aspect of nature, the real romance of the countryside, the real meaning of life." Doily Telegraph. 

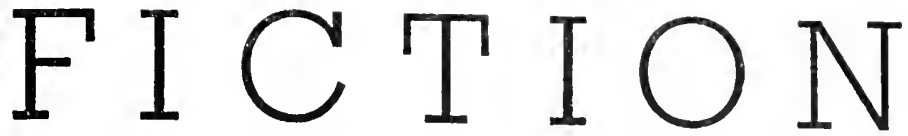

- A fine human novel by a young novelist with a rising reputation

\section{DOROTHY A. HUNT}

Author of "Unfettered" (Daily Mirror Romantic Book of the Month), "Reflection".

\section{Vagabonds All}

As the title suggests this is a story of the road. Not, however, the road that winds over hill and dale and comes to rest on heath or common, where at fall of evening vagrants and vagabonds gather around the camp fire, but the road that lies between shop and store, office and warehouse; the road that is traversed by millions of feet in the course of everyday life, leaving their impression, indelibly if unconsciously, on the path they tread.

It was destined that Pat should become a commercial traveller. She pursued her star faithfully, learning sometimes through bitter, sometimes humorous experiences the road to success - success that counted so little in the scales of love.

A very human story that will appeal not only to the romantic minded but to all those who have encountered in any way the ironies and difficulties that beset a commercial life.

There is originality in this story. There is also passion and pettiness, temptation and tears, love and laughter-the inevitable accompaniment of human nature wherever one encounters it, brought very skilfully to bear on the canvas of everyday things.

All three of Miss Hunt's novels have been the story of a girl's life. Not least among them is the story of this little countryborn girl who faces so dauntlessly the snubs and setbacks, complications and obstacles of that most difficult, humiliating. but withal fascinating career-of the road.

Crown 8 vo.

7s. 6d. net 
- A brilliant new novel by an author of extensive repute

\section{ROBERT HICHENS \\ Secret Information}

by the author of "Afterglow" and "The Garden of Allah".

This story is a study of an English clergyman, Rector of an important church in London, and Canon of a cathedral in the south of England.

Although universally respected for a long time, and by many greatly admired, he has an ugly secret.

He enjoys, as it were, two lives: the life of the famous preacher, the successful Rector, the popular Canon, during the greater part of the year: a quite different life when he travels alone, as he does annually on his holiday. In the house-he is a residentiary Canon-attached to his Canonry there is a locked cupboard. Nobody has access to this cupboard but himself. In this cupboard there is something which, if seen and examined by intelligent eyes, would expose the hidden part of his nature, the part which has its yearly fling when he travels alone.

During the course of the story, inadvertently in the pulpit when preaching one night in the cathedral, the Canon says something which makes one of his hearers, an extremely acute barrister, who is one of his neighbours in the country, suspect that he is probably not the respectable, if not actually holy, man he seems, and is supposed to be. From this moment the drama of the story begins.

The Canon's butler, an ex-soldier, finds out what is there. The secret information becomes his possession. What happens then, and how eventually the barrister is able to verify his suspicions that the Canon is not what he seems to be to the eyes of the world. and how the Canon endeavours to get rid of the evidence against him which he has kept concealed in the cupboard, make the substance of the story, which shifts from the cathedral town to London and back again.

Crown 8vo.

7s. 6d. net 


\section{FICTION}

- Thrills and humour in an exciting tale!

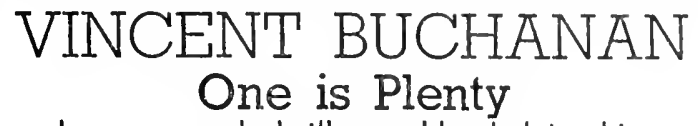

Romance, humour, and thrills are blended in this story of a military attaché to Preskova, a capital of Eastern Europe. He becomes involved with the beautiful Mlle Kscscz (pronounced Kiss-kiss) who is in a situation of some difficulty. Captain Bottomfax, nothing if not susceptible to feminine charm in distress, cannot fail to come to her aid-with romantic results. Unfortunately, when he returns to England, the determined Moira, also beautiful, insists on helping him in a new and dangerous assignment, and soon Captain Bottomfax finds himself in the disastrous position of being engaged to two girls at once! The situation is further complicated, with exciting effect, when he learns that Mlle Kscscz has arrived at his father'sGeneral Bottomfax's-house, and that his parents, through some extraordinary complication caused by Miss Elaine Astolat, the celebrated film-star, are about to become divorced.

The unravelling of this tangle provides fun, fast and furious, and excitement on every page to the end. Captain Bottomfax himself is a creation of quality ; simple in his reactions to feminine allure, with a heart ever ready to be shattered by beauty, he is nevertheless a man of resource and initiative when faced by the dangers of his profession. This is a book of charm and unfailing entertainment.

Crown 8vo.

$7 s .6 d$, net

- New Novel by the author of "The Snake Charmer", etc.

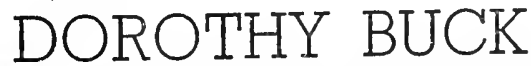

When the Aloe Bloomed

by the author of "The Snake Charmer", etc.

This is the story of life on a lonely African plantation, of the mysterious and sinister influence at work on that plantationthe dread finger of a past that touches each character in turn. Mrs. O'Brien, the terrifying old woman with the big gnarled hands ; Lyn, the sly, fair, faun-like youth whose secret no one 
knows ; Zohra, the mysterious native girl who has a snakespirit ; Paul, the lovely, unlucky child in whom the past lives again-all these figures live under a dread and deepening shadow. How Vera, the sensitive heroine, finds the courage to save Paul and thus finds her own happiness, makes a poignant story, and a true picture of the strange life of the exile.

Crown 8 ro.

7s. 6d. net

- Thrilling tale of a modern soldier of fortune

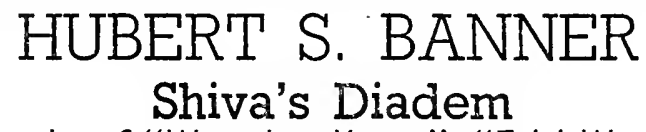

by the author of "Wanted on Voyage", "Tidal Wove", etc.

This is a story of ends that were shaped by Destiny in a capricious mood. When "Beery" Hind, soldier of fortune, squire of dames, champion of lost causes, and-in his spare timefree-lance journalist, dropped into Antwerp's "red-light quarter" to kill an idle hour he little dreamed himself on the threshold of an adventure that would take him to the Channel Islands, Canada, and, ultimately, the Dutch East Indies. But how was he to know that he would find Lola van Marcken in the very act of vamping Jake Woolly?

Crown 8vo.

7s. 6d. net

- A detonation of mirth by a quick-fire gloomshatterer

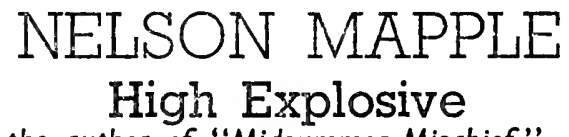

by the author of "Midsummer Mischief", etc.

When Professor James Ryan blew himself and his laboratory sky high in the summer of 1918, it was thought generally that he had taken with him the secret of "P.O.P.", the deadliest explosive ever invented. By the time, however, that Europe had again entered the arms race, certain rumours were current that this was not so, but that someone was walking round with the "P.O.P." formula tattooed on his or her body. 


\section{FICTION}

To find this person, and, when found, also to find the tattoo, soon became the absorbing occupation of not only Mike Henderson, unemployed stock-broker's clerk, but also of the unscrupulous International Arms Syndicate.

Then, to add zest to the search, the British Government, acting through Scotland Yard, unleashed Detective-Inspector Sandwich and Sergeant "Gussie" Shark ; and Hampye Island, off the Sussex coast, became the exciting centre of a whirlpool of hilarious intrigue in which Alison Ryan, fashionable dresscreator, and Sally Kampfer, American heiress, revolved-helpless in the grip of events. YOU'LL LOVE IT.

Crown 8 vo.

7s. 6d. net

\section{- Romance of a Viennese girl in Scotland}

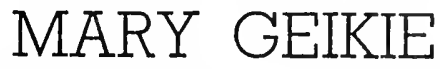

\section{Have Patience, Griselda}

by the author of "Reeds in the River", etc.

The story opens in Vienna. Grizel Murray, although of Scottish parentage, has, by an odd chain of circumstances, been brought up in Austria. Left an orphan at eighteen, she has the choice of marriage to an Austrian or a return to Scotland, where her step-sister, the wife of the headmaster of a boy's public school, offers her a home. The Austrian marriage is unpalatable, Grizel decides to go to Scotland.

Alas, the reality is not at all what her fancy had painted. She finds herself in a small world of jealousy and gossip where her natural friendliness and love of fun are constantly misconstrued. Romance, however, manages to lift its head, bids fair indeed to become the dominant theme, until the mysterious disappearance of a manuscript and the suspicions surrounding its loss produce more friction and trouble. The step-sister's spite and Grizel's own pride complicate things still further. It takes an accident, in which the hero nearly loses his life. to resolve the discords and allow the sorely tried headmaster to say: "All's well that ends well." Crown 8vo.

7s. 6d. net 
A book deep and lovely and satisfying

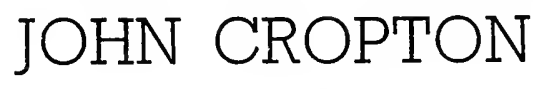

\section{Heaven's Silence}

by the author of "The Road to Nowhere".

An unusually lovely novel this, dominated always by the cottages and people and craggy, quiet hills of Cumberland. John Hennessey is the son of the Rev. Gilbert Hennessey, rector of a country parish in the Eden valley, Cumberland.

To the placid Rectory come Rex and his mother, widow of one of the rector's closest friends. The thoughtful, solitary John is disturbed by their coming, for Rex is an unpleasant, snobbish, and boastful character and the two clash continually.

Later, when the boys are almost grown up, Rex comes again to the Rectory, and the climax of this part of the book comes when Rex and John and his father go on a rock-climbing expedition during which Rex's foolhardiness leads them into dangers from which only the rector's technique, courage, and presence of mind saves them. John's father is no longer young and is almost exhausted by his efforts; John tells Rex just what sort of a fool he is, but afterward apologizes at the instigation of his father, though he knows that he was only telling Rex the truth.

There is a brief, vivid, war sequence in which Rex becomes a major behind the lines, John a captain in them ; and a dramatic passage when Rex's true colours show in the stress of battle.... Then comes Joan, who marries Rex, and John worships from afar ; but at the end it is John who triumphs, in the knowledge that he has won his manhood and his soul and finds tranquillity beside those noble, shadowy hills in the north.

This is a story of rare insight and power; in it one sees the "Heaven's Silence" of the hills of Cumberland become gradually the "heaven's silence" in a soul. . . .

Crown 8 vo.

7s. 6d. net 


\section{FICTION}

\section{- Brilliant thriller of a muddled murder...}

\section{H. R. TAUNTON Six Foot of Rope}

by the author of "It Prowls At Dark".

Nearly all thrillers and crime stories lay claim to be called "unusual" ; but we feel that this brilliant tale does so with justification.

The story commences with George Marchant and Leo Campion, cousins, rifling the safe of old John Campion. They are surprised by him, and George, meaning to stun him so as to stop him from raising the alarm, kills him. Leo, weak and irresponsible, loses his head and bolts ... and as it happens, all the evidence points to him as the murderer. George, stronger and cooler, faces the music and remains unsuspected. He knows, however, that as soon as Leo is caught he will be charged, at best, as an accessory. He knows, too, that Leo, unaided, is too incompetent to remain at large for long. He contrives to get into touch with him; and excitement and thrills surround his efforts to save Leo from the results of his persistent folly, to get him out of the country, and at the same time to avoid suspicion of himself as an active agent in the escape.

The clash of the opposing characters of the two men, the growing suspicion and hatred engendered by the stress of their desperate situation as they are chased across England by an unlucky but persistent C.I.D. man, the gathering impetus of event and circumstance, at last force George to the inevitable "Dead men tell no tales".

The last chapters work up to a great climax which leaves the C.I.D. man and his inspector a riddle to solve which is baffling in its complexity. Perhaps it is not surprising that the solution they provide is the wrong one and that the correct one should be discovered by a woman who loved both men.

Crown 8vo. 


\section{FICTION}

- A beautiful study of love in persecution

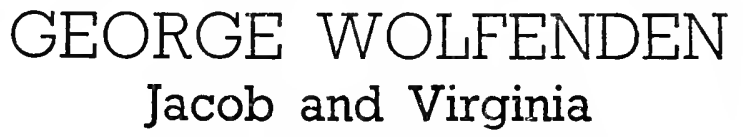

by the author of "The House in Spitolfields".

The story of Virginia Mendle, a girl whose beginnings and destiny were alike mysterious, how she came to Wandler's, the Spitalfields moneylender's, and there fell in love with jacob Joyce in the face of the bitterest persecution. The portrait of Frederick Wandler, professedly the most upright of men, but hand in hand with London's underworld, is something new in fiction. The secret marriage of Jacob with Virginia, the extraordinary fate that befell them and their subsequent adventures provide a narrative of unforgettable power and conviction.

Crown 8 ro.

7s. 6d. net

\section{- A bizarre, fascinating story of the occult}

\section{G. WYNDHAM HASLETT \\ Portrait in Shadows}

by the author of "The House of Illusion", "Merrivale and Fossiter" (Book Society Recommendation).

In this original and striking novel the interest centres round that attraction of the human mind towards the occult which draws so many and diverse types of people into the dingy parlour of the professional fortune-teller. Isobel March is an orphan whose only tie in life is a wealthy and tyrannous old aunt who makes use of her niece as a kind of companion and general drudge. Isobel, however, is one day suddenly awakened by a gypsy palmist to a belief in an impending reversal of the conditions of her whole existence. This belief, working by degrees upon a nature unbalanced by loneliness and suppression, becomes in time an obsession and produces a spiritual crisis of the first magnitude-a crisis which, stopping not far 
short of madness, leads to the very brink of murder. In the end, as the result of a swift and unexpected development, Isobel returns to normality, and out of an experience that came perilously near to proving fatal there emerges the regeneration of an individual soul.

Crown 8 vo.

7s. 6d. net

\section{- "Miss Forster should make a name for herself."-Daily Telegraph}

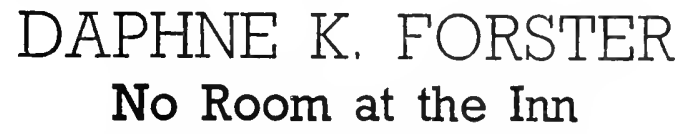

by the author of "Faulty Mosaic", etc.

Miss' Forster's new novel is set for the most part in idyllic surroundings in Dorset but, as in all this author's work, it is of course the people who really matter. And if a story that is mainly concerned with love is a love-story, then that is what this is. But it is far from being a mere sugary romance. The characters are too vividly realized, and too much thought and insight have gone to the writing of the novel for that.

It is, in the main, the story of a girl who is far too alive, too eager for experience, too intelligent and too curious to be satisfied with the friends and possible lover that a country village can provide-who fortuitously meets and later falls in love with a man much older, much more experienced, than herself. He in turn is suffering from the disillusionment of a tempestuous marriage, which has finally foundered on the rocks and left him with the latter part of his life to remake. But their tale is only the main thread of a novel rich in britliantly observed secondary characters. In particular, the heroine's sister, Shirley, is a sensitive and loving portrait. She, and old Crane and his sons, and Mr. Harrington, the girl's queer father, and the various other residents of the village, make up a collection of people that one lives with rather than reads about in this third novel by the author of "Strangers All, and "Faulty Mosaic".

Crown 8 vo.

7s. 6d. net 


\section{FICTION}

\section{- Peter Clancy again!}

\section{LEE THAYER \\ This Man's Doom}

by the outhor of "The Lost Trump", "Death in the Gorge", etc. If Top Hat Rafferty had remained on the straight and narrow path ; if Peter Clancy, by what we call chance, had not happened to stop in on the night when the extortion note was first disclosed, the case of the Graytowers murder might never even have come to light.

For who but Peter would have asked those searching questions about the hangman's knot and the tiny wound? Why the victim's pistol was not fired. And how it came to be so far under the bed. Why Whittlesey had seemed so ready to accede to the blackmailer's demand. So much care had been taken to leave no clues, surely the local police were justified in pouncing on those that did appear and in taking them at their face value. Only Peter's long experience made it possible to realize that the absence of a thing that should inevitably appear is sometimes more significant than the most obviously damaging piece of evidence.

And on this assumption, the astute private investigator, followed and supported by his faithful Wiggar, moves swiftly through these pages to the amazing denouement.

Crown 8vo.

7s. 6d. net

- Here's a puzzle for you!

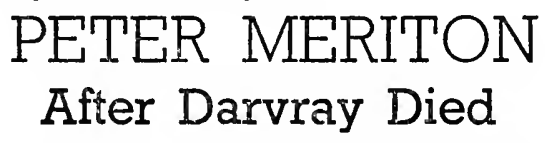

by the outhor of "Three Die at Midnight".

A living man's honour in a dead man's hand. That is the situation with which Peter Meriton deals in his second novel, "After Darvray Died".

Paul Darvray wove a cunning net for the trapping of Michael Gray, a net in which Gray became so entangled that only the 


\section{FICTION}

hand of Darvray could release him. And then the unreckoned factor made itself apparent. Paul Darvray was murdered, the meshes of his net still tight about the feet of Michael Gray.

As in Peter Meriton's first novel, Bill Langley and his ineffable manservant, Stokes, play a prominent part, and with them are just as unusual a gallery of characters as figured in "Three Die at Midnight".

Crown 8vo.

7s. 6d. net

- This will fascinate you as you sit by your fireside

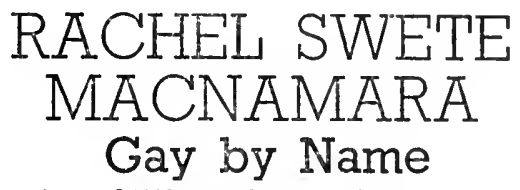

by the author of "Kiss a Stranger", "Fandango", etc.

When Rosanna Leigh arrives at the little Alpine village of Bryon-accompanied by Stephen Filmer-Gay Beauchamp and Jim Hervey, a young Indian Civil Servant, are on the point of becoming engaged. Gay loves Jim very dearly, but his feeling for her is rather affection than love.

With him and Rosanna, however, it is a case of love at first sight.

Stephen Filmer, a rich young man who has proposed to Gay several times without success, does so again. This time, for various reasons, she accepts him.

The story tells how these readjustments work out. How, when Rosanna's babies come, the age-old Indian problem arises, husband or children. Which Rosanna chooses and what happens, how Jim nearly comes to shipwreck, how Gay saves him and with what result, must be read in the novel itself, which is one of the best this author has yet given us. It delves deep into the intricacies of the human heart, is rich in observation of character and scene, and is written with all Rachel Swete Macnamara's usual grace and charm.

Crown 8vo.

7s. 6d. net 


\section{FICTION}

- A bizarre and thrilling tale

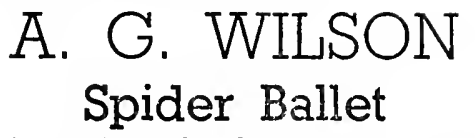

by the author of "Come Away Death".

To the wail and throb of violins, the quickening beat of notes in counterpoint from the basses, and high, weird trills from the woodwind, a slim, lovely figure on a floodlit stage twirls, points slender toes, waves graceful arms in a mad, hastening tarantella. The Spider Ballet is ending . . .

The music quickens until it seems that no dancer could ever keep pace with its rushing tempo, yet the flying figure keeps on ... the audience gasps, holds its breath; a woman screams as the tension screws nerves to breaking-point . . .

The slender, the lovely dancer in the glare of the lights spins, as a dying bird fluttering away its life, and collapses in a huddled heap on the boards. The lights go out ...

Such is the setting for the tremendous finale of this dramatic story of a ballet dancer, Nida, who is in the power of a mad composer, Peppin ; of the love of the contra-bass player, Clement Shornell, for her and of his final victory in the struggle for her soul.

Crown 8vo.

7s. 6d. net

- Ingenious and well-developed new thriller by

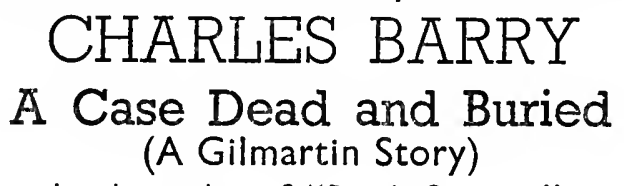

by the author of "Death Overseas".

Giovanni Cortelli, gangster and racketeer, poisoned a wife who had become an encumbrance, and shot a New York patrolman who tried to arrest him for the crime. Then he disappeared-apparently without trace.

No case, however-certainly no case involving the death of 
a policeman-is considered "dead and buried" until the criminal is also below ground or otherwise brought to book: and so, ten years later, when Charles Barry's story opens. John Cottrell, a young West Country landowner, is arrested at the instance of New York Police Headquarters whose representative in England maintains that he is really Cortelli and demands his extradition to the United States.

There is more than the similarity of names to support the American's contention, and ex-Superintendent Gilmartin, Barry's popular sleuth of many successes, emerges from his retirement to play an unfamiliar and difficult role.

We are not giving too much away when we say that the reader will be satisfied that thanks to their joint efforts a particularly ugly bogey is interred, justice is done, and, in fact, the Cortelli affair is finally a case dead and buried.

Crown 8vo.

7s. 6d. net

\section{- And yet another fine Peter Clancy!}

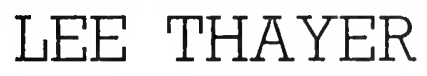

\section{Ransom Racket}

by the author of "The Last Trump", etc.

Peter Clancy has a new assignment. Robbery, intrigue. and sudden death have always been an everyday occurrence in his exciting life, but curiously enough, the Seaton case is his first experience with that most detestable of all crimes, kidnapping. Faced by an entirely novel and sinister set of circumstances, he is forced to piece together a series of seemingly trivial facts to unravel the complicated tangle. The tracks in the snow that should and should not have been there... the significance and the colour of a certain person's eyes ... what terrible things happen when dead men come to life-in all these lie subtle meanings and only through Clancy's ingenuity are they drawn together to form the startling solution.

"Ransom Racket" is an absorbing story which never lags as it speeds its way with precision to an airtight finish.

Crown $8 v 0$.

7s. 6d. net 


\section{FICTION}

- Another entrancing Indian romance by

\section{E. W. SAVI \\ Ill-Gotten Gains}

by the author of "The Soothsayer", "Riddle of the Hill", etc.

A wealthy financier of Bengal dictates and signs a will on his death-bed, determined that his only daughter in England should be saved from dependence on her stepmother, whom he disinherits. This will is placed in the hands of the executor, and is lost the following night when the safe is burgled and its contents removed. All that can be done is done to trace it, without success.

In the meantime, the widow is able to produce another will which was signed and witnessed correctly during the same illness, and this one makes her the sole legatee. As no other is forthcoming, it is proved valid by law and she and her two daughters by her first marriage come into possession of all that should have passed to the dead man's daughter.

As a compensating gesture, this very modern young woman is brought out to India to share the family life. How she and they react to the circumstances; how she proves more than competent to deal with the situations that arise; and how blackmai! rears its evil head threatening the hopes and the stability of certain amateur criminals is the story, which is set in the glamorous atmosphere of the East with all its colourful and sinister possibilities.

Crown 8 vo.

7s. 6d. net

- New Oriental thriller by

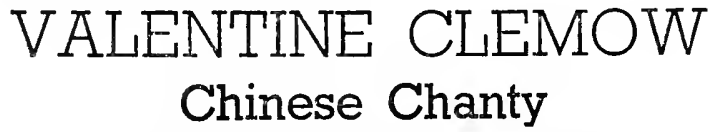

by the author of "Brother of the Dark", etc.

"Chinese Chanty" gives a picture of conditions in Southern China prior to the present Sino-Japanese war. It is a story of adventure-dope-smuggling, piracy, murder in a quiet 


\section{FICTION}

European house in Kowloon, the clash of rival War Lords. It is also a love story; or, rather, three love stories, with the glamorous background of Hong-Kong. The chief characters are a group of British naval officers and their wives, and the action takes place during the two years of their service on the China Station.

Hinimohe Jocelyn, beautiful orphaned heiress, and still in her teens, is on her way out to Hong-Kong to marry Lieutenant "Nick" Crecy when she meets Paul Deverell and falls a victim to his practised wiles. The unexpected arrival of Paul's supposed wife, Laurette, now married to Commander Fenwick, further complicates the situation. The third triangle consists of Don Sandring, superintendent of a line of ships concerned in the dope smuggling, his wife and the designing widow, Phyllis Avon.

A skilful blending of thrills and romance, of light comedy and stark tragedy, added to the convincingly portrayed main theme of one woman's undying love and devotion, make this one of the most charming books written by this popular author.

Crown 8 vo.

7s. 6d. net

\section{- Love and Enchantment in a new Romance by}

\section{H. M. E. CLAMP \\ Desert's Daughter}

by the author of "The Sheik Desires", etc.

Ferideh el Bedawi, the sixteen years old orphaned daughter of a great Sheik and a French mother, rides into the story on her blood-Arab "Dajli" and finds invaders in her desert territory. Glave Randolph, attractive bachelor, has a camp in an oasis and Ferideh, glimpsing the handsome Englishman, decides that she will have him for her lord.

The little desert despot has no idea that Allah will deny her anything, or that any man dare resist her. She follows him to Cairo in the guise of a chic French girl, but eventually has to have him captured by her tribesmen.

There, in her desert home, love-war rages furiously between

Page Forty-Nine 


\section{FICTION}

them, and she endeavours to break him in, but is forced to learn that love cannot be demanded.

She lets him go, and from that moment it is up to the Englishman.

Crown 8 vo.

7s. 6d. net

- Charming, lively, modern; a new story by

\section{BARBARA STANTON}

Bachelors Have Such Fun!

by the author of "Rhythm Romeo", "Love's a Luxury", etc.

Tells the delightfully human story of a wealthy, attractive bachelor, who despite many narrow squeaks, somehow manages to avoid the perilous seas of matrimony. No mere idle philanderer, this Norman Abbot, but a real flesh-and-blood character who values his freedom so much that at the mere mention of the word "marriage" he begins to run for his life. Listen to him discussing the subject with another bachelor friend :

"Marriage, old boy! The form of suicide I should choose last. Look at all our friends who get caught. Before marriage, gay, bright lads with hope in their hearts and an odd bob or two in their pockets. Good for an evening's fun, able to stand their round of drinks with the next man. In short-MEN. But after marriage, ye gods! Faces lined with worry, pockets lined with bills. Daren't miss that 6.15 in the evening. See them surreptitiously sucking cachous in the train lest their sweet little wives-ugh !-suspect them of that half-a-bitter their bachelor friends stand them. Watch the furtive way they creep about in their own homes, paid for by the sweat of their own brow. Married men-in other words, LIVING CORPSES !"

All very well, of course, but that was before Norman met Monica Morgan, the dazzling little red-head who wrought such havoc in his luxurious, well-ordered life.

Humour, romance, sophistication-all are found in this delightful novel by a writer whose popularity is increasing by leaps and bounds.

Crown 8 vo.

7s. 6d. net 


\section{FICTION}

- New novel by a writer of quality

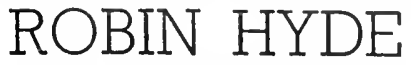

\section{The Godwits Fly}

by the outhor of "Wednesday's Children", etc.

"Godwits" are birds which migrate continuously from one point to another. In Miss Hyde's new book they are personified by the Hannays-John, Augusta his wife, and their children, Carly, Eliza and Sandra.

John Hannay is a clerk, poorly paid, at the same time conscious of his poverty and intolerant of the state of affairs which allows and produces his misery. He is a bitter socialist and atheist. He and his family move from place to place continuously in search of jobs for him ; Augusta is irritated by him and his ideas and longs for security at any price.

The story after a while is taken up by the children and here Miss Hyde's genius asserts itself completely. Their parents, life itself, is shown through the eyes of Carly, Eliza and Sandra as only Miss Hyde can feel and see as children do.

Gradually the book becomes the life of Eliza, with her struggles, her poetry and her lovely imagination. All the qualities of "Wednesday's Children"-its tenderness, charm, and queer, sudden humour are in Eliza with an added strength of characterization and a deeper view of life which comes with the more realistic story.

This is a lovely book and a powerful one, and will enhance a considerable reputation.

Crown 8vo

7s. 6d. net

- A new Western for $3 / 6$ !

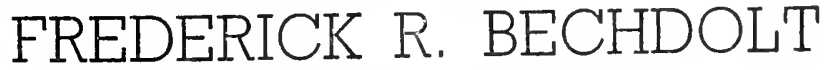

\section{The Tree of Death}

by the outhor of "Horse Thief Trail".

A new book by this master of the action story.

Crown 8 vo.

3s. 6d. net

Page Fifty-One 
- Gripping reconstruction of History

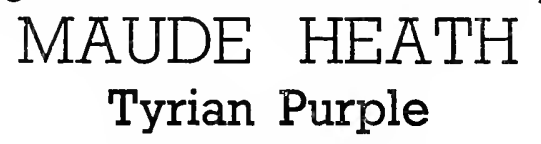

by the author of "Herb o' Grace"

Remembered by her remarkable first novel, "Herb o' Grace". which covered three reigns of English History, Maude Heath now takes her readers deep into the past, when Phoenician ships sailed to Britain, and when Tyre was mistress of the Mediterranean.

The story is related by Amra the freed-woman, to a generation who knew the Princess of Tyre and Queen of Israel only as a legendary figure, about whom had gathered rumours of magic and the attributes of beauty, statecraft, and ruthless courage. Sometimes Sety the Phoenician mariner takes up the tale. sometimes a precious papyrus scroll or cylinder of baked clay unfolds the narrative. In Maude Heath's pages a dead world lives once more, its men and women are as real as those we meet today. Passion, intrigue, vengeance, the din of battle have their place side by side with ambition, charlatanism, and the might of Jehovah against the worship of Baal.

Maude Heath not only knows history but makes it part of her being. To scholarship and research she brings the vital spark which vivifies an epoch.

Crown 8 vo.

7s. 6d. net

\section{- IN PREPARATION}

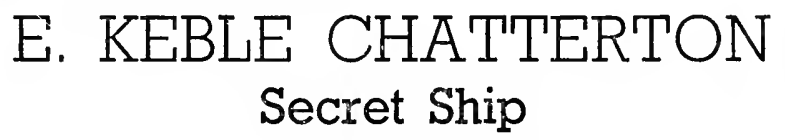

by the author of "Sea Spy", etc.

In "Secret Ship" the reader is again entertained by thrilling situations and a continuous series of remarkable happenings, with an enthralling romance from the first page to the end. 
Using the sea and ships for background, brilliant sunshine, exciting intrigue, an ingenious plot, rich colouring, a charming heroine and real men, this is just the story to take you out of yourself and make you forget everything but the non-stop tale of how Fate seized likable, lovable people in its grasp.

If you want to be carried away into a fascinating series of high adventures, put "Secret Ship" down on your list. Mr. Chatterton "writes of the sea as only a sailor can", and in "Secret Ship" he eclipses all his previous books.

Cr. 8vo.

7s. 6d. net

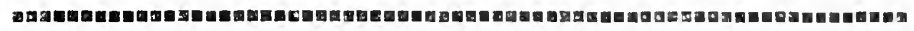

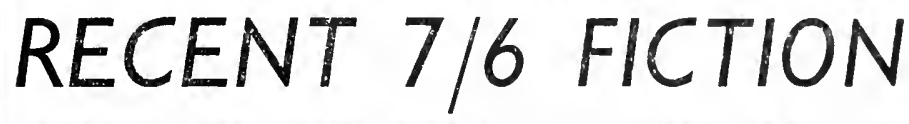

SIME

THE SHEIK DESIRES

GREEN THANKSGIVING

REFLECTION

BYE, BYE, BLACKBEARD

KISS A STRANGER

FAULTY MOSAIC

I'VE BEEN TO LONDON

THE HOUSE IN SPITALFIELDS

YELLOW DUSK

BROTHER OF THE DARK

WEDNESDAY'S CHILDREN

WIND'S WHISPER

DEATH OVERSEAS

DUSTY SHOES

THE ROAD BESET
H. M. E. Clamp Marion Reid-Jamieson

Dorothy A. Hunt Nelson Mapple. Rachel Swete Macnamara Daphne K. Forster Temple Bailey George Wolfenden Bettina Bedwell Valentine Clemow Robin Hyde Herbert Best Charles Barry Patrick Turnbull Eustace Ainsworth 


\section{HURST \& BLACKETT'S POPULAR $3 / 6$ net NOVELS}

Crown 8vo. Printed on good paper and bound in cloth. New titles in italic; projected titles underlined.

ALBANESI, MADAME

The Young Man from the Country

Marian Sax

Strongest of all Things

A Question of Quality

Drusilla's Point of View

\section{APPLIN, ARTHUR}

Sweeter than Honey

The Death Mask

Cold Cream

Picked Up

\section{ASKEW,}

\section{ALICE and CLAUDE}

In an Orchard Close

Freedom

Fate and Drusilla

\section{BAILEY, TEMPLE}

Fair as the Moon

Enchanted Ground

Silver Slippers

The Tin Soldier

Little Girl Lost

Dim Lantern

Blue Window

Wallflowers

Trumpeter Swan

Wild Wind

Glory of Youth

Burning Beauty

Peacock Feathers

Mistress Anne

Contrary Mary

BANNER, HUBERT $S$.

Wanted on Voyage

\section{BARCYNSKA, COUNTESS}

jackie

ILoved a Fairy

A Certified Bride

Pretty Dear

Russet Jacket

Ships Come Home

Publicity Baby

Exit Renee

Love Maggy

Under the Big Top

A Woman of Experience

Decameron Cocktails

Mint Walk

The Honey-Pot

Hand-Painted

Back to the Honey-Pot

BARRE, JEAN

Restive Lovers

Second Harvest

Rabbits in Fate's Hat

Pride of Race

\section{BARRY, CHARLES}

Death in Darkness

Poison in Public

The Shot from the Door

Death of a First Mate

The Wrong Murder Mystery

BECHDOLT,

FREDERICK $R$.

Horse Thief Trail

Riders of the San Pedro

BEST, HERBERT

Low River 


\section{POPULAR 3/6 net NOVELS-continued}

BINNIE, MARJORIE

VVomen with Men

BLOOM, URSULA

The Trackless Way

\section{BORDEUX, VAHDAH}

Step Husband

BRADDON, M. E.

Her Convict

BREHM, BRUNO

That Was the End

BROADHURST,

THOMAS, A.B.

Blow the Man Down

BUCK, DOROTHY

The Last Oasis

Love Affair

Dark Cavalier

CARDELL, WILLMAR

Perhaps Things Matter

CHATTERTON, E. KEBLE

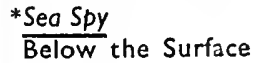

CLAMP, H. M. E.

\section{* Celestial Adventure}

\section{Rebel Angels}

Son of Argent
CLAMP, H. M. E.

(continued)

Man Alone

The White Ras

Wild Cat

Barn Owl

Africa's Daughter

Jungle Woman

Brat

Eternal as the Sphinx

Veldt Man

Legion of the Desert

Nile Water

Lava

The Power and Glory Girl

Feather Bed Jane

The Great God Jazz

Stained Glass

Golden Rod

Venus, Ltd.

The Sexless Trinity

The Sheik of Montmartre

Beauty Mask

Desert Sand

COFFIN, GEOFFREY

Murder in the Senote

COMSTOCK, HARRIET

Sacrifice for Love

The Mark of Cain

Karen's Destiny

COUSINS, E. G.

\section{Will Not Ceose}

CROKER, MRS. B. M.

\section{Her Own People}

The Youngest Miss Mowbray The Company's Servant

* These titles are_scheduled for April-June, 1938 
POPULAR $3 / 6$ net NOVELS-continued

DRAGO, HARRY

SINCLAIR

Guordian of the Sage

Montana Road

Trigger Gospel

Desert Water

DU JARDIN, ROSAMOND

All is not Gold

DUTTON, CHARLES J.

Black Fog

EDMONDS, WALTER D.

Erie Water

ELLSBERG, COMMANDER EDWARD

Submerged: An Epic of the Submarine Service

\section{ELSNA, HEBE}

Upturned Palms

Half Sisters

Women Always Forgive

You Never Knew

Study of Sara

We are the Pilgrims

Other People's Fires

All Swans

Strait-Jacket

The Third Wife

Child of Passion

Sweeter Unpossessed

ELWENSPOEK, DR. CURT Jew Süss Oppenheimer

ENGLAND, JANE

The Barrier

Trader's Licence
ENGLAND, JANE

(continued)

Outspan

No Endings

Rhodesian Farm

Come Home Again

The Years of the Locust

Distaff

Young Simpson

No Traveller Returns

The Sjambok

Skyline

EX-LEGIONNAIRE 1384

The Soulless Legion

FARADAY, W. BARNARD

The Milk in the Cocoonut

FORSTER, DAPHNE $K$.

*Strangers All

FRANKAU, PAMELA

The Foolish Apprentices

She and I

Born at Sea

I was the Man

Marriage of Harlequin

FREE, RICHARD

Dearly Beloved Brethren

GALLON, TOM

Fortunes A-begging

GARDINER, DOROTHY

The Golden Lady

GATES, H. L.

The Caballero

* This title is scheduled for April-June, 1938 


\section{POPULAR 3/6 net NOVELS-continued}

\section{GELZER, JAY}

Prima Donna

GRIMSHAW, BEATRICE

Black Sheep's Gold

HALLAM, HIPWELL

HERMIONE

Ninas of Balcarce

HAMILTON, COSMO

Laughing Mask

Undelivered Letters

Scandal

Another Scandal

Mrs. Skeffington

At Whose Door?

HAMILTON, HARRY

Banjo on My Knee

HAYES, MILTON

Bad Men Make Good Wives

HELLER, HENRIK

Wanted a Nurse

HICKEY, T. F. W.

Nancy Emery

HOLMES, L. P.

* Law of Kyger Gorge

Roaring Range

\section{HORLER, SYDNEY}

The House of Wingate

\section{HOWARD, ANKARET}

Portrait of Maud

\section{HUNT, DOROTHY}

*Unfettered

HYDE, ROBIN

Check to Your King

Passport to Hell

JAMES, JAMES

Guide Book to Women

JOELSON, ANNETTE

Blind Living

KERRUISH, JESSIE

DOUGLAS

Babylonian Nights

LANDI, ELISSA

The Ancestor

LAWRENCE, MARGERY

Terraces of Night

Silken Sarah

The Madonna of Seven Moons

The Drums of Youth

Bohemian Glass

LEADERMAN, GEORGE

Death in Pursuit

LEAVELLE, ELIZABETH

Blind Harvest

LE BOURNE, M.

The Harp of Time

Ever Rolling Stream

* These titles are scheduled for April-June, 1938

Page Fifty-Seven 


\section{POPULAR 3/6 net NOVELS-continued}

\section{LEEDS, ELODIE}

Dancing Marathon

\section{LE QUEUX, WILLIAM}

Man from Downing Street

Devil's Carnival

The Unnamed

\section{LESLIE, DORIS}

The Starling

\section{LEWIS, HILDA}

Madame Gold

Pegasus Yoked

Full Circle

\section{LORD, JEREMY}

The Bannerman Case

\section{MACNAMARA,}

\section{RACHEL SWETE}

\section{Fandango}

The Lovely Ghost

Strange Encounter

The White Witch

Duet for a Trio

Glass Walls

Pagans Limited

The Awakening

Let Them Say

Cross Roads

The Trance

Drifting Waters

Spinners in Silence

Seeds of Fire

A Marriage has been Arranged Cock Angel

The Dragon Tree

Burnt Fingers

Morning Joy

Torn Veils

Golden Dishes
MACNAMARA, RACHEL

SWETE (continued)

Marsh Lights

Stolen Fruit

Lark's Gate

The Green Shoes of April

The Crowded Temple lealous Gods

Lover's Battle

MANN, E. B.

The Terror of Tombstone Trail Gamblin' Man

Thirsty Range

Stampede

The Man from Texas

Killer's Range

MARGRAVE, PHYLLIS

Fickle Wheel

MARSHALL, BRUCE

The Stooping Venus

MERITON, PETER

*Three Die at Midnight

MONSARRAT, NICHOLAS

At First Sight

OLIPHANT, MRS.

The Cuckoo in the Nest

\section{PAGE, GERTRUDE}

Where the Strange Roads go Down

Some There Are

* This title is scheduled for April-June, 1938 


\section{POPULAR 3/6 net NOVELS-continued}

PAGE, GERTRUDE

(continued)

Winding Paths

Follow After

Love in the Wilderness

The Rhodesian

The Great Splendour

The Silent Rancher

Paddy-the-Next-Best-Thing

The Edge o' Beyond

\section{PAUL, LESLIE}

Fugitive Morning

Periwake

\section{PETERS, JULIE}

\section{African Gift}

Helen Cranton

Sacrifice

The Singing Forest

Brood of Folly

Illusory Gold

The Little Gods Laughed

\section{PETERSON, MARGARET}

The Unknown Hand

The Pitiful Rebellion

Dear Lovely One

Life-and a Fortnight

The Question

Flame of the Forest

Passionate Particles

Like a Rose

Deadly Nightshade

Adventurous Youth

Butterfly Wings

To Love

Love is Enough

Love's Burden

Fate and the Watcher

First Stone

Death Drum

Moon Mountains
POLLEXFEN, CLAIRE D.

The Call of the Horizon

RACHMONOVA, ALJA

My Milkshop in Vienna

REYNOLDS,

MRS. BAILLIE

The Sheikh Touch

In the Balance

To Set Her Free

The Ides of March

RIVES, AMELIE

(Princess Troubetzkoy)

The Elusive Lady

World's End

ROGERS, SAMUEL

* Lucifer in Pine Lake

Dusk at the Grove

ROWLANDS,

\section{EFFIE ADELAIDE}

judged by Fate

Love's Fire

A Strange Love Story

The Fault of One

The Man with the Mone

Her Heart's Longing

The Woman's Fault

Lavender's Love Story

His One Love

* This title is scheduled for April-June, 1938

Page Fifty-Nine 


\section{POPULAR 3/6 net NOVELS-continued}

\section{SANDYS, OLIVER}

Tiptoes

Spangles

Sir Boxer

Happy Day

Just Lil

Butterflies

The Five-Hooded Cobra

Squire

jinks

Bad Lad

Mr. Scribbles

Misty Angel

Cherry

Blinkeyes

The Curled Hands

Champagne Kiss

Sally of Slopers

Tilly-Make-Haste

Mr. Anthony

Pleasure Garden

Sally Serene

Green Caravan

Chappy-That's all

The Crimson Ramblers

The Ginger Jar

Old Roses

Vista, the Dancer

The Garment of Gold

Mops

The Sorceress

SAVI, E. W.

*The Soothsoyer

The Riddle of the Hill

Passionate Problem

The Glamorous East

The Tyranny of Freedom

Prisoners of Necessity

On the Knees of the Gods

The Tree of Knowledge

The Blunder

A Blind Alley

By Torchlight

In Desperation

At Close Quarters

Law Divine
SAVI, E. W. (continued)

God-Forsaken

The Unattainable

The Door Between

The Great Gamble

A Forlorn Hope

The Acid Test

On Trust

Vagrant Love

White Lies

Baba and the Black Sheep

Mistress of Herself

A Fool's Game

On the Rack

Daggers Drawn

Neither Fish nor Flesh

Sackcloth and Ashes

A Prince of Lovers

Satan Finds

Making Amends

Breakers Ahead

Sinners All

Dog in the Manger

The Inconstancy of Kitty

Taken by Storm

The Other Man

The Fatalist

Reproof of Chance

Daughter-in-Law

SENIOR, F. D. PONSONBY

The Diary of Mrs. Pepys

\section{SERGEANT, ADELINE}

Casper Brooke's Daughter

The Claim of Anthony Lockhart

\section{SIMENON, GEORGES}

Introducing Inspector Moigret

Inspector Moigret Investigotes

\section{SPERO, LEOPOLD}

There's no Forgetting

* This title is scheduled for April-June, 1938 


\section{POPULAR 3/6 net NOVELS-continued}

STANTON, BARBARA

Three make their Bed

* Rhythm Romeo

John Wainwright's Wife

Love's a Luxury

Honeymoon Husband

Melody's Monch

STEVENS, E. S.

Ishtar

Sophy

STOCKLEY, CYNTHIA

Poppy

The Claw

SWAN, ANNIE S.

The Broad Road

TAUNTON, H. R.

Death in Diamonds

THAYER, LEE

The Puzzle

Poison

The Key

Death in the Gorge

Murder in the Mirror

The Counterfeit Bill

Hell Gate Tides

Scrimshaw Millions

The Glass Knife

To Catch a Thief

The Death Weed

The Second Shot

\section{TURNBULL, PATRICK}

Red Walls
VEGESACK,

SIEGFRIED VON

The House Devouring

WARWICK, COUNTESS OF, AND REED, LANGFORD

The Prime Minister's Pyjomas

WEES, FRANCES SHELLEY

It Began in Eden

WEIMAN, RITA

What Manner of Love

WENTWORTH-JAMES, G. de S.

The Television Girl Rarebit

WHITBY, BEATRICE

Bequeathed

WILLIAMSON, MRS. C. N.

The Turnstile of Night

WILSON, A. G.

Come Away Death

WYLLARDE, DOLF

As Ye Have Sown Mafoota

The Holiday Husband

* This title is scheduled for April-June, 1938 


\section{-TOUCAN POCKET}

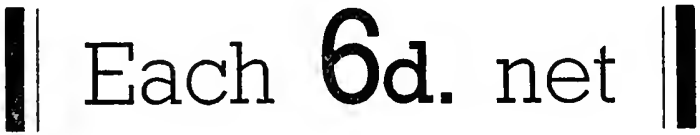

- WITH ATTRACTIVE COLOURED JACKETS

1. THE DOCTOR'S DEFENCE

2. TROUBLE BREWING

3. WIFE OF RICHARD

4. THE PURPLE ROCK

5. MOPS

6. TESHA

7. THE SHEIK OF MONTMARTRE

8. THE UNATTAINABLE

9. GOLDEN ROD

10. THE TREE OF KNOWLEDGE

11. BUTTERFLY WINGS

12. VISTA, THE DANCER

13. A CUCKOO IN HARLEY STREET

14. COURTSHIP IN KENYA

15. THE SCREAMING GULL

16. HIGH PRESSURE

17. THE AVENGER

18. THE FORMULA

19. RAGAMUFFIN

20. CHICANE

21. RELUCTANT SINNERS

22. CLACKING SHUTTLES

23. GABRIEL'S GARDEN

24. MIXED PICKLES

25. GREEN SHOES OF APRIL

26. THE BROAD ROAD

27. SILKEN SARAH

28. BLOW THE MAN DOWN
Sidney Fairway Joan Butler

Mona Messer Angus MacVicar

Oliver Sandys

Countess Barcynska

H. M. E. Clamp E. W. Savi

H. M. E. Clamp

E. W. Savi

M. Peterson

Oliver Sandys

Sidney Fairway Nora K. Strange Angus MacVicar Joan Butler Edgar Wallace Sydney Horler Maysie Greig Oliver Sandys Sidney Fairway Florence Bone Cecil Adair Joan Butler Rachel Swete Macnamara Annie S. Swan Margery Lawrence Thomas W. Broadhurst 


\section{WELCOME}

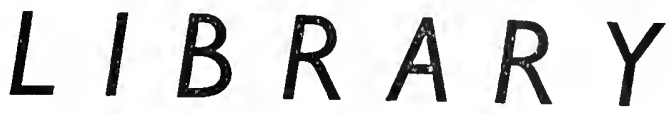

-Each 3d. net

- A new series of books for the pocket by well-known authors. With attractive covers in colour.

1. THE HONEY-POT

Countess Barcynska

2. A PRINCE OF LOVERS E. W. Savi 3. STRIP GIRL Evadne Price 4. HER HEART'S LONGING Effie Adelaide Rowlands

5. HELL ROARIN' TEXAS TRAIL Robert Denver

6. FINAL PAYMENT Arthur Applin 7. THE BLUE BUNGALOW William Le Queux Further volumes in preparation 


$$
623^{8}
$$






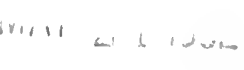


